\title{
INFLUÊNCIA DA ESTRATÉGIA DE ALIMENTAÇÃO NO DESEMPENHO DO REATOR ANAERÓBIO EM \\ BATELADA SEQÜENCIAL CONTENDO BIOMASSA
}

IMOBILIZADA

\section{ALISSON CARRARO BORGES}

Dissertação apresentada à Escola de Engenharia de São Carlos da Universidade de São Paulo como parte dos requisitos para obtenção do título de Mestre em Engenharia, área de concentração: Hidráulica e Saneamento.

Orientador: Prof. Dr. José Alberto Domingues Rodrigues

São Carlos

2003 
FOLHA DE JULGAMENTO

Candidato: Engenheiro ALISSON CARRARO BORGES

Dissertação defendida e julgada em 07-04-2003 perante a Comissão Julgadora:

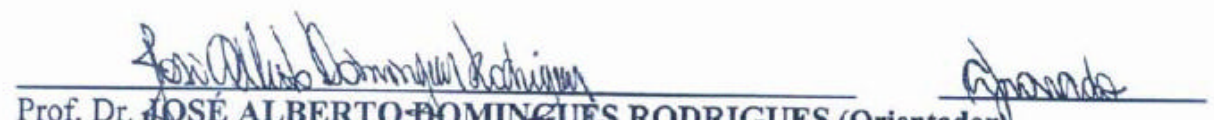
Prof. Dr. WSÉ ALBERTO ĐOMINĖUES RODRIGUES (Orientador) (Escola de Engenharia de Mauá/CAEEM)

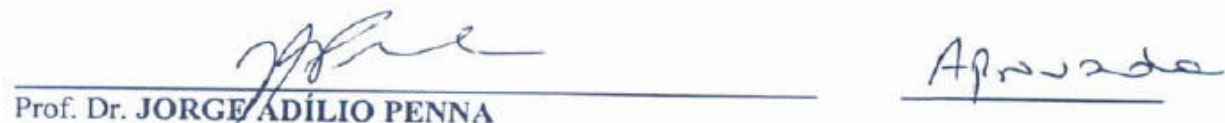

Prof. Dr. JORGE/ADÍLIO PENNA

(Universidade Federal de Ouro Preto/UFOP)

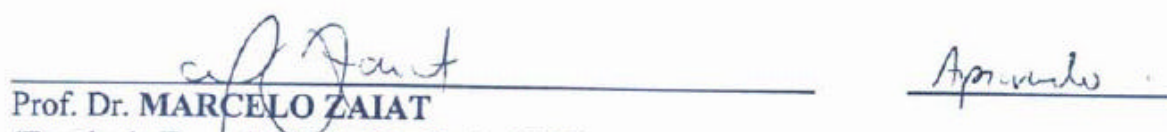

(Escola de Engenharia de São Carlos/USP)

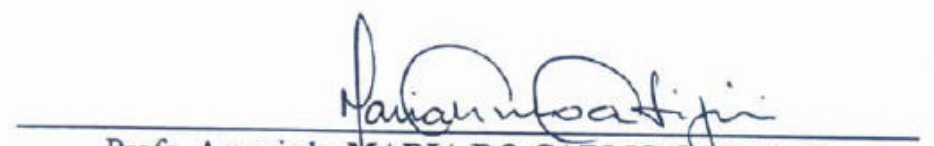

Profa. Associada MIARIA DO CARMO CALIJURI

Coordenadora do Programa de Pós-Graduação em

Engenharia (Hidráulica e Saneamento) e

Presidente da Comissão de Pós-Graduação 


\section{DEDICATÓRIA}

À família Carraro, minha primeira escola. 


\section{MANIFESTO N. ${ }^{\circ} 11$ DA SOCIEDADE ALTERNATIVA}

\section{Prefácio e Saudação}

Nós vos saudamos, Maria. Nós vos saudamos José. E nós saudamos os artistas brasileiros que tiveram o silêncio do resto do mundo quando seus trabalhos e seus corpos foram censurados, mutilados, desaparecidos.

\section{Manifesto}

1. O espaço é livre. Todos têm direito de ocupar seu espaço.

2. O tempo é livre. Todos têm de viver em seu tempo, e fazer jus às promessas, esperanças e armadilhas.

3. A colheita é livre. Todos têm direito de colher e se alimentar do trigo da criação.

4. A semente é livre. Todos têm o direito de semear suas idéias sem qualquer coerção da INTELEGENZIA ou da BURRICIA.

5. Não existe mais a classe dos artistas. Todos nós somos capazes de plantar e de colher. Todos nós vamos mostrar ao mundo e ao MUNDO a nossa capacidade de criação.

6. "Todos nós" somos escritores, donas de casa, patrões e empregados, clandestinos e caretas, sábios e loucos. 
7. E o grande milagre não será mais ser capaz de andar nas nuvens ou caminhar sobre as águas. O grande milagre será o fato de que todo dia, de manhã até a noite, seremos capazes de caminhar sobre a Terra.

\section{Saudação final do $11 .^{\circ}$ manifesto}

Sucesso a quem ler e guardar este manifesto. Porque nós somos capazes. Todos nós, todos nós somos capazes. Raul Seixas, Paulo Coelho, Sylvio Passos, Christina Oiticica, Toninho Buda, Ed Cavalcanti. 


\section{AGRADECIMENTOS}

A Deus, por tudo. "É bom louvar ao Senhor e cantar salmos ao vosso nome ó Altíssimo; proclamar de manhã a vossa misericórdia, e a noite a vossa fidelidade”.

À Maria Santíssima, que sob seu manto acolhe todos aqueles que a vossa intercessão recorrem, obrigado pela proteção a minha família.

A meus pais, Francisco Borges Pinto e Margarida de Jesus Carraro Borges, pelo exemplo de vida, amor e dedicação.

Ao Dr. José Alberto Domingues Rodrigues, pela amizade, orientação e dedicação ao trabalho.

À FAPESP pelo auxílio financeiro e pela bolsa de estudos concedida.

A todos os colaboradores que por esquecimento ou falta de espaço (sic) não tiveram seus nomes registrados nessa seção.

Às pessoas que, cada um a sua maneira, contribuíram para a concretização deste sonho, minha sincera gratidão (a ordem dos fatores não altera o produto):

Suzana Maria Ratusznei, Raul Seixas, Renato Ribeiro Siman, Estéfano Aparecido Vieira, José Roberto Oliveira, Maria Aparecida Catarino Ventura, irmãos pif pafianos, Baltus Bonse , Jimmy Hendrix, Marcelo Zaiat, Marcílio Souza Rocha Freitas, Jorge Adílio Penna, Pedro José Machado e família, José Roberto Campos, Família Pereira Pinto, Aline Márcia Carraro Borges, Gregor Friedl, amigos do LEB/EEM, Tibério Magalhães Pinheiro, Holden Robson Amorim, Fábio Lavor Teixeira, Monique Toledo Salgado, André Coelho, Eloísa Pozzi Gianotti, funcionários do SHS/EESC/USP, Sergio Brasil Abreu, Maria do Carmo Calijuri, Valdecir Benassi, Sérgio Luís Siebra Moreira, turma SHS 2001, Ana Paula Carraro 
Borges, Roberto Antônio Bezerra Júnior, João Fernandes Viana Moreira, The Beatles.

Às seguintes instituições pelo apoio logístico e "logístico" na realização deste trabalho:

Clube Atlético Mineiro, eterna República Pif Paf, Rádio 89 FM, Bar do Maguila, Partido dos Trabalhadores, centenária Escola de Minas/ UFOP, Supremo Lanches, Galö Metal, CAEM, Sociedade São Vicente de Paulo, Programa Especial de Treinamento, CAASO, Ócio Café Bar, Escola de Engenharia de São Carlos/ USP, Asa Norte Rock Bar, Escola de Engenharia Mauá/ IMT, AmBev.

E que nossos dias sejam preguiçosos e longos... 


\section{SUMÁRIO}

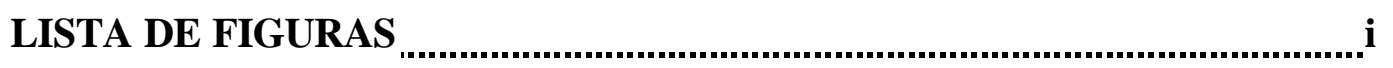

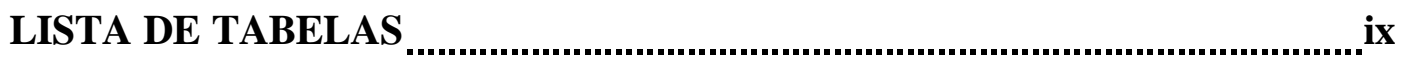

LISTA DE ABREVIATURAS E SIGLAS ..................................................

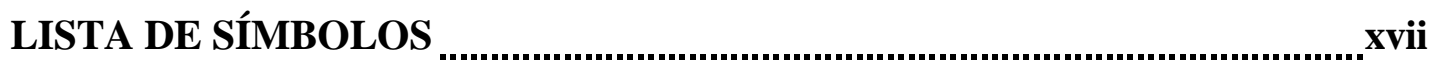

RESUMO

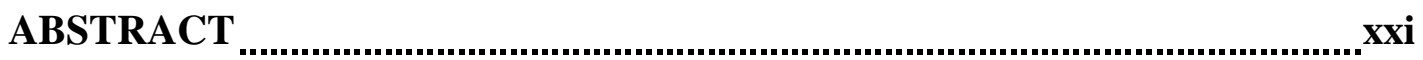

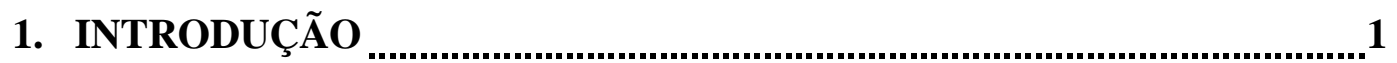

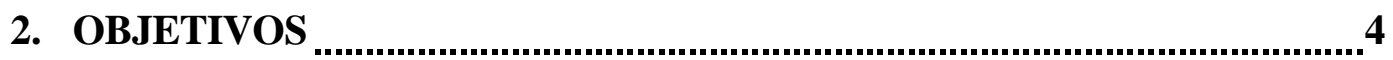

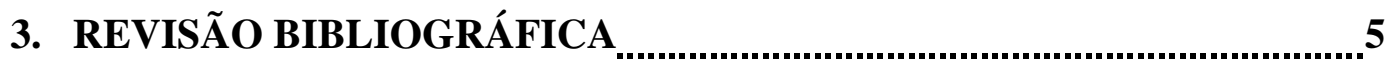

3.1. Noções de qualidade e poluição das águas .....................................5

3.2. Fundamentos do tratamento anaeróbio ...................................... 7

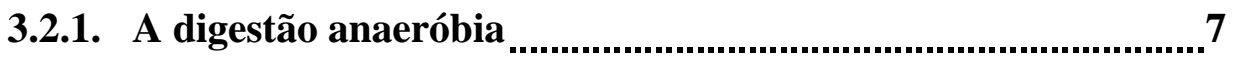

3.2.2. Fatores importantes na digestão anaeróbia .........................11

3.3. A disseminação da tecnologia anaeróbia no tratamento de águas residuárias 
3.4. Reator anaeróbio operado em batelada seqüencial - ASBR 17

3.4.1. Introdução 17

3.4.2. Princípio de funcionamento 18

3.4.3. Vantagens e aplicações 20

3.5. Estudo das variáveis de influência na operação de um ASBR 23

3.5.1. Introdução 23

3.5.2. Imobilização da biomassa 25

3.5.3. Estratégia de alimentação 30

3.6. Considerações finais 34

4. MATERIAIS E MÉTODOS 35

4.1. Materiais 35

4.1.1. Configuração do Reator 35

4.1.2. Material suporte para imobilização da biomassa 39

4.1.3. Inóculo 39

4.1.4. Água residuária 40

4.2. Fundamentos teóricos 42

4.2.1. Eficiência de remoção de matéria orgânica 42

4.2.2. Ajuste do modelo cinético aos dados experimentais 43

4.3. Métodos analíticos 46

4.3.1. Análises físico-químicas 46

4.3.2. Análises microbiológicas 47 
4.4. Procedimento experimental 48

4.4.1. Imobilização da biomassa anaeróbia 48

4.4.2. Operação do reator 49

4.4.3. Obtenção dos perfis ao longo do ciclo 51

4.4.4. Análise dos sólidos presentes na espuma de poliuretano 53

4.4.5. Análise dos resultados experimentais 54

\section{RESULTADOS E DISCUSSÃO}

5.1. Operação e perfis de desempenho ao longo do ciclo para diferentes estratégias de alimentação 56

5.1.1. Ensaio preliminar em batelada $(8 \mathrm{~h})$ para a verificação do funcionamento do sistema e ajustes operacionais 56

5.1.2. Operação do reator em batelada $(8 \mathrm{~h})$ 61

5.1.3. Operação do reator em batelada alimentada $(2 \mathrm{~h})$ seguida de batelada (6 h) 68

5.1.4. Operação do reator em batelada alimentada $(4 \mathrm{~h})$ seguida de batelada ( $4 \mathrm{~h})$ 77

5.1.5. Operação do reator em batelada alimentada $(6 \mathrm{~h})$ seguida de batelada ( 2 h) 86

5.1.6. Operação do reator em batelada alimentada $(8$ h) 94

5.2. Comparação da eficiência e estabilidade do sistema, quando submetido às diferentes estratégias de alimentação 102

5.3. Estudo cinético para os experimentos com diferentes estratégias de alimentação 110

5.4. Análises microbiológicas da biomassa imobilizada 116 
7. REFERÊNCIAS BIBLIOGRÁFICAS 126

APÊNDICES

Apêndice I Detalhes construtivos do reator

Apêndice II Variáveis monitoradas do afluente do reator anaeróbio operado em batelada alimentada seqüencial

Apêndice III Variáveis monitoradas do efluente do reator anaeróbio operado em batelada alimentada seqüencial

Apêndice IV Perfis ao longo do ciclo do reator anaeróbio operado em batelada alimentada seqüencial 164

Apêndice V Valores obtidos no ajuste do modelo cinético de primeira ordem aos dados dos perfis dinâmicos de concentração de matéria orgânica 182 


\section{LISTA DE FIGURAS}

FIGURA 3.1: Representação esquemática do processo metabólico da digestão anaeróbia. Fonte: HARPER \& POHLAND (1986)...9

FIGURA 3.2: Etapas de operação de um reator anaeróbio operado em batelada seqüencial. Fonte: DAGUE et al. (1992). 19

FIGURA 3.3: Efeito da alimentação em batelada na concentração de substrato e na razão F/M. Fonte: DAGUE et al. (1992). 20

FIGURA 4.1: Esquema do reator anaeróbio operado em batelada seqüencial contendo biomassa imobilizada. 36

FIGURA 4.2: $\quad$ Fotografia da montagem experimental. 37

FIGURA 4.3: Detalhe do reator confeccionado em acrílico com o cesto contendo espuma de poliuretano com biomassa imobilizada. . 38

FIGURA 4.4: Fotografia do cesto de aço inoxidável, onde foi alocada a espuma de poliuretano com a biomassa imobilizada. 39

FIGURA 4.5: Cubos de espuma de poliuretano antes e após a imobilização da biomassa.

FIGURA 5.1: Concentração de matéria orgânica, em termos de DQO, durante o ensaio preliminar em batelada $(8 \mathrm{~h})$. 58

FIGURA 5.2: $\quad$ Eficiência de remoção de matéria orgânica obtida no ensaio preliminar em batelada $(8 \mathrm{~h})$. 58

FIGURA 5.3: Alcalinidade a bicarbonato durante o ensaio preliminar em batelada $(8 \mathrm{~h})$ 60 
FIGURA 5.4: Concentração de ácidos voláteis totais durante o ensaio preliminar em batelada $(8 \mathrm{~h})$. 60

FIGURA 5.5: Concentração de matéria orgânica, em termos de DQO, para a operação em batelada $(8 \mathrm{~h})$. 62

FIGURA 5.6: Eficiência de remoção de matéria orgânica obtida no ensaio em batelada $(8 \mathrm{~h})$ 63

FIGURA 5.7: Alcalinidade a bicarbonato durante o ensaio em batelada $(8 \mathrm{~h})$. 63

FIGURA 5.8: Concentração de ácidos voláteis totais durante o ensaio em batelada $(8 \mathrm{~h})$. 64

FIGURA 5.9: Perfis de concentração de substrato ao longo da batelada (8 h). 65

FIGURA 5.10: Perfis de alcalinidade a bicarbonato ao longo da batelada $(8 \mathrm{~h})$.

FIGURA 5.11: Perfis de concentração de ácidos voláteis totais ao longo da batelada $(8 \mathrm{~h})$ 67

FIGURA 5.12: Concentração de matéria orgânica, em termos de DQO, para a operação em batelada alimentada ( 2 h) seguida de batelada $(6 \mathrm{~h})$.

FIGURA 5.13: Eficiência de remoção de matéria orgânica obtida no ensaio em batelada alimentada $(2 \mathrm{~h})$ seguida de batelada $(6 \mathrm{~h})$. 71

FIGURA 5.14: Alcalinidade a bicarbonato durante o ensaio em batelada alimentada ( $2 \mathrm{~h})$ seguida de batelada $(6 \mathrm{~h})$. 
FIGURA 5.15: Concentração de ácidos voláteis totais durante o ensaio em batelada alimentada $(2 \mathrm{~h})$ seguida de batelada $(6 \mathrm{~h})$. 72

FIGURA 5.16: Perfis de concentração de substrato ao longo da batelada alimentada ( $2 \mathrm{~h})$ seguida de batelada $(6 \mathrm{~h})$ 73

FIGURA 5.17: Perfis de alcalinidade a bicarbonato ao longo da batelada alimentada ( 2 h) seguida de batelada (6 h). 74

FIGURA 5.18: Perfis de concentração de ácidos voláteis totais ao longo da batelada alimentada $(2 \mathrm{~h})$ seguida de batelada $(6 \mathrm{~h})$. 75

FIGURA 5.19: Perfis de concentração de metano ao longo da batelada alimentada (2 h) seguida de batelada $(6 \mathrm{~h})$ 75

FIGURA 5.20: Perfis de concentração de dióxido de carbono ao longo da batelada alimentada $(2 \mathrm{~h})$ seguida de batelada $(6 \mathrm{~h})$. 76

FIGURA 5.21: Fração molar média, em porcentagem, de $\mathrm{CH}_{4}$ e $\mathrm{CO}_{2}$ ao longo da batelada alimentada $(2 \mathrm{~h})$ seguida de batelada $(6 \mathrm{~h}) .76$

FIGURA 5.22: Concentração de matéria orgânica, em termos de DQO, para a operação em batelada alimentada (4 h) seguida de batelada (4 h). 80

FIGURA 5.23: Eficiência de remoção de matéria orgânica obtida no ensaio em batelada alimentada (4 h) seguida de batelada (4 h). 80

FIGURA 5.24: Alcalinidade a bicarbonato durante o ensaio em batelada alimentada (4 h) seguida de batelada (4 h) 81

FIGURA 5.25: Concentração de ácidos voláteis totais durante o ensaio em batelada alimentada (4 h) seguida de batelada $(4 \mathrm{~h})$. 81 
FIGURA 5.26: Perfis de concentração de substrato a longo da batelada alimentada (4 h) seguida de batelada (4 h) 82

FIGURA 5.27: Perfis de alcalinidade a bicarbonato ao longo da batelada alimentada (4 h) seguida de batelada $(4 \mathrm{~h})$. 83

FIGURA 5.28: Perfis de concentração de ácidos voláteis totais ao longo da batelada alimentada (4 h) seguida de batelada (4 h). 83

FIGURA 5.29: Perfis de concentração de metano ao longo da batelada alimentada (4 h) seguida de batelada (4 h) 84

FIGURA 5.30: Perfis de concentração de dióxido de carbono ao longo da batelada alimentada (4 h) seguida de batelada (4 h). 84

FIGURA 5.31: Fração molar média, em porcentagem, de $\mathrm{CH}_{4}$ e $\mathrm{CO}_{2}$ ao longo da batelada alimentada (4 h) seguida de batelada (4 h). 85

FIGURA 5.32: Fotografia do material polimérico viscoso presente no cilindro onde foi alocado o eixo de agitação, ao final do ensaio em batelada alimentada (6 h) seguida de batelada $(2 \mathrm{~h})$. 87

FIGURA 5.33: Concentração de matéria orgânica, em termos de DQO, para a operação em batelada alimentada (6 h) seguida de batelada $(2 \mathrm{~h})$. 89

FIGURA 5.34: Eficiência de remoção de matéria orgânica obtida no ensaio em batelada alimentada $(6 \mathrm{~h})$ seguida de batelada $(2 \mathrm{~h})$. 89

FIGURA 5.35: Alcalinidade a bicarbonato durante o ensaio em batelada alimentada (6 h) seguida de batelada $(2 \mathrm{~h})$. 
FIGURA 5.36: Concentração de ácidos voláteis totais durante o ensaio em batelada alimentada $(6 \mathrm{~h})$ seguida de batelada $(2 \mathrm{~h})$. 90

FIGURA 5.37: Perfis de concentração de substrato ao longo da batelada alimentada (6 h) seguida de batelada $(2 \mathrm{~h})$. 91

FIGURA 5.38: Perfis de alcalinidade a bicarbonato ao longo da batelada alimentada (6 h) seguida de batelada (2 h). 92

FIGURA 5.39: Perfis de concentração de ácidos voláteis totais ao longo da batelada alimentada $(6 \mathrm{~h})$ seguida de batelada $(2 \mathrm{~h})$. 92

FIGURA 5.40: Perfis de concentração de metano ao longo da batelada alimentada $(6 \mathrm{~h})$ seguida de batelada $(2 \mathrm{~h})$..............................93

FIGURA 5.41: Perfis de concentração de dióxido de carbono ao longo da batelada alimentada $(6 \mathrm{~h})$ seguida de batelada $(2 \mathrm{~h})$. 93

FIGURA 5.42: Fração molar média, em porcentagem, de $\mathrm{CH}_{4}$ e $\mathrm{CO}_{2}$ ao longo da batelada alimentada $(6 \mathrm{~h})$ seguida de batelada $(2 \mathrm{~h}) .94$

FIGURA 5.43: Concentração de matéria orgânica, em termos de DQO, para a operação em batelada alimentada $(8 \mathrm{~h})$. 97

FIGURA 5.44: Eficiência de remoção de matéria orgânica obtida no ensaio em batelada alimentada $(8 \mathrm{~h})$. 97

FIGURA 5.45: Alcalinidade a bicarbonato durante o ensaio em batelada alimentada $(8 \mathrm{~h})$.

FIGURA 5.46: Concentração de ácidos voláteis totais durante o ensaio em batelada alimentada $(8 \mathrm{~h})$. 98

FIGURA 5.47: Perfis de concentração de substrato ao longo da batelada alimentada (8 h). .. 99 
FIGURA 5.48: Perfis de alcalinidade a bicarbonato ao longo da batelada alimentada (8 h).

FIGURA 5.49: Perfis de concentração de ácidos voláteis totais ao longo da batelada alimentada $(8 \mathrm{~h})$.

FIGURA 5.50: Perfis de concentração de metano ao longo da batelada alimentada $(8 \mathrm{~h})$

FIGURA 5.51: Perfis de concentração de dióxido de carbono ao longo da batelada alimentada $(8 \mathrm{~h})$.

FIGURA 5.52: Fração molar média, em porcentagem, de $\mathrm{CH}_{4}$ e $\mathrm{CO}_{2}$ ao longo da batelada alimentada $(8 \mathrm{~h})$.

FIGURA 5.53: Eficiência de remoção de substrato $(\varepsilon)$ no reator.

FIGURA 5.54: Fotografia do material polimérico viscoso presente no cilindro onde foi alocado o eixo de agitação ao final do ensaio em batelada alimentada $(8 \mathrm{~h})$

FIGURA 5.55: Fotografia do material polimérico presente no impelidor e no eixo de agitação ao final do ensaio em batelada alimentada $(8 \mathrm{~h})$

FIGURA 5.56: Vista superior do sistema, com formação de polímeros extracelulares, ao final do ensaio em batelada alimentada $(8 \mathrm{~h})$ 108

FIGURA 5.57: Ajuste dos perfis obtidos para a operação em batelada (8 h)... 111

FIGURA 5.58: Ajuste dos perfis obtidos para a operação em batelada alimentada ( $2 \mathrm{~h})$ seguida de batelada $(6 \mathrm{~h})$. 
FIGURA 5.59: Ajuste dos perfis obtidos para a operação em batelada alimentada (4 h) seguida de batelada (4 h).

FIGURA 5.60: Ajuste dos perfis obtidos para a operação em batelada alimentada (6 h) seguida de batelada $(2 \mathrm{~h})$.

FIGURA 5.61: Ajuste dos perfis obtidos para a operação em batelada alimentada $(8 \mathrm{~h})$

FIGURA 5.62: Coeficientes cinéticos obtidos para as diferentes estratégias de alimentação.

FIGURA 5.63: Morfologias observadas nas espumas de poliuretano através de microscopia ótica: células semelhantes a bacilos e víbrios. 117

FIGURA 5.64: Morfologias observadas nas espumas de poliuretano através de microscopia ótica: células semelhantes a espiroquetas e víbrios.

FIGURA 5.65: Morfologias observadas nas espumas de poliuretano através de microscopia ótica: células semelhantes víbrios com inclusões.

FIGURA 5.66: Morfologias observadas nas espumas de poliuretano através de microscopia ótica: célula metanogênica semelhante a Methanosaeta $\mathrm{sp}$

FIGURA 5.67: Morfologias observadas nas espumas de poliuretano através de microscopia ótica: células metanogênicas semelhantes a Methanosaeta sp. 
FIGURA 5.68: Morfologias observadas nas espumas de poliuretano: células semelhantes a Methanosarcina sp.

FIGURA 5.69: Morfologias observadas nas espumas de poliuretano através de microscopia ótica (contraste de fase): células semelhantes a bacilos hidrogenotróficos..

FIGURA I.1： $\quad$ Aspectos construtivos: vista superior do reator........................... 138

FIGURA I.2: $\quad$ Aspectos construtivos: vista principal do reator. ....................... 139

FIGURA I.3: Aspectos construtivos: corte transversal B............................. 140

FIGURA I.4: $\quad$ Aspectos construtivos: corte transversal A. ................................ 141 


\section{LISTA DE TABELAS}

TABELA 3.1: $\quad$ Dados experimentais obtidos em ASBRs. 22

TABELA 4.1: Composição percentual da matéria orgânica no substrato. Fonte: TORRES (1992). 40

TABELA 4.2: Composição da água residuária sintética utilizada nos experimentos. Fonte: TORRES (1992). 41

TABELA 5.1: Valores médios das variáveis monitoradas no ensaio preliminar em batelada $(8 \mathrm{~h})$.

TABELA 5.2: Valores médios das variáveis monitoradas no ensaio em batelada (8 h)

TABELA 5.3: Valores médios das variáveis monitoradas no ensaio em batelada alimentada $(2 \mathrm{~h})$ seguida de batelada $(6 \mathrm{~h})$. 69

TABELA 5.4: Valores dos sólidos da biomassa imobilizada (inóculo) contida no reator operado em batelada alimentada $(2 \mathrm{~h})$ seguida de batelada $(6 \mathrm{~h})$.

TABELA 5.5: Valores médios das variáveis monitoradas no ensaio em batelada alimentada (4 h) seguida de batelada (4 h) 78

TABELA 5.6: Valores dos sólidos da biomassa imobilizada (inóculo) contida no reator operado em batelada alimentada $(4 \mathrm{~h})$ seguida de batelada $(4 \mathrm{~h})$.

TABELA 5.7: Valores dos sólidos da biomassa imobilizada (inóculo) contida no reator operado em batelada alimentada $(6 \mathrm{~h})$ seguida de batelada ( $2 \mathrm{~h}$ ). 
TABELA 5.8: Valores médios das variáveis monitoradas no ensaio em batelada alimentada $(6 \mathrm{~h})$ seguida de batelada $(2 \mathrm{~h})$. 88

TABELA 5.9: Valores médios das variáveis monitoradas no ensaio em batelada alimentada $(8 \mathrm{~h})$. 95

TABELA 5.10: Valores dos sólidos da biomassa imobilizada (inóculo) contida no reator operado em batelada alimentada $(8 \mathrm{~h})$. 96

TABELA 5.11: Variáveis monitoradas no reator para as diferentes estratégias de alimentação.

TABELA 5.12: Variáveis monitoradas no reator para as diferentes estratégias de alimentação.

TABELA 5.13: Variáveis monitoradas no reator para as diferentes estratégias de alimentação.

TABELA 5.14: Sólidos presentes no reator monitorados durante diferentes estratégias de alimentação.

TABELA 5.15: Valores obtidos pelo modelo ajustado aos dados experimentais.

TABELA II.1: Valores monitorados do afluente utilizado no ensaio preliminar em batelada $(8 \mathrm{~h})$.

TABELA II.2: Concentrações de sólidos no afluente utilizado no ensaio preliminar em batelada $(8 \mathrm{~h})$.

TABELA II.3: Valores monitorados do afluente utilizado no ensaio em batelada (8 h).

TABELA II.4: Valores das concentrações de sólidos no afluente utilizado no ensaio em batelada $(8 \mathrm{~h})$. 
TABELA II.5: Valores monitorados do afluente utilizado no ensaio em batelada alimentada (2 h) seguida de batelada $(6 \mathrm{~h})$.

TABELA II.6: Valores das concentrações de sólidos no afluente utilizado no ensaio em batelada. alimentada $(2 \mathrm{~h})$ seguida de batelada $(6 \mathrm{~h})$.

TABELA II.7: Valores monitorados do afluente utilizado no ensaio em batelada alimentada (4 h) seguida de batelada (4 h)..

TABELA II.8: Valores das concentrações de sólidos no afluente utilizado no ensaio em batelada alimentada $(4 \mathrm{~h})$ seguida de batelada $(4 \mathrm{~h})$................................................................................ 148

TABELA II.9: Valores monitorados do afluente utilizado no ensaio em batelada alimentada $(6 \mathrm{~h})$ seguida de batelada $(2 \mathrm{~h})$.

TABELA II.10: Valores das concentrações de sólidos no afluente utilizado no ensaio em batelada alimentada $(6 \mathrm{~h})$ seguida de batelada $(2 \mathrm{~h})$.

TABELA II.11: Valores monitorados do afluente utilizado no ensaio em batelada alimentada $(8 \mathrm{~h})$.

TABELA II.12 Valores das concentrações de sólidos no afluente utilizado no ensaio em batelada alimentada $(8 \mathrm{~h})$.

TABELA III.1: Resultados obtidos no ensaio preliminar em batelada (8 h)..... 152

TABELA III.2: Resultados obtidos no ensaio preliminar em batelada (8 h).... 153

TABELA III.3: Resultados obtidos no ensaio preliminar em batelada ( 8 h)..... 153

TABELA III.4: Resultados obtidos no ensaio em batelada ( $8 \mathrm{~h})$. 154

TABELA III.5: Resultados obtidos no ensaio em batelada ( $8 \mathrm{~h})$. 155 
TABELA III.6: Resultados obtidos no ensaio em batelada $(8 \mathrm{~h})$.

TABELA III.7: Resultados obtidos no ensaio em batelada alimentada ( $2 \mathrm{~h}$ ) seguida de batelada $(6 \mathrm{~h})$.

TABELA III.8: Resultados obtidos no ensaio em batelada alimentada $(2 \mathrm{~h})$ seguida de batelada $(6 \mathrm{~h})$.

TABELA III.9: Resultados obtidos no ensaio em batelada alimentada (2 h) seguida de batelada $(6 \mathrm{~h})$

TABELA III.10: Resultados obtidos no ensaio em batelada alimentada (4 h) seguida de batelada $(4 \mathrm{~h})$.

TABELA III.11: Resultados obtidos no ensaio em batelada alimentada (4 h) seguida de batelada $(4 \mathrm{~h})$.

TABELA III.12: Resultados obtidos no ensaio em batelada alimentada (4 h) seguida de batelada $(4 \mathrm{~h})$.

TABELA III.13: Resultados obtidos no ensaio em batelada alimentada (6 h) seguida de batelada $(2 \mathrm{~h})$

TABELA III.14: Resultados obtidos no ensaio em batelada alimentada (6 h) seguida de batelada $(2 \mathrm{~h})$.

TABELA III.15: Resultados obtidos no ensaio em batelada alimentada (6 h) seguida de batelada $(2 \mathrm{~h})$.

TABELA III.16: Resultados obtidos no ensaio em batelada alimentada (8 h).... 162

TABELA III.17: Resultados obtidos no ensaio em batelada alimentada ( 8 h).... 163

TABELA III.18: Resultados obtidos no ensaio em batelada alimentada (8 h).... 163

TABELA IV.1: Perfis de concentração de substrato e eficiência de remoção ao longo do ciclo para o ensaio em batelada $(8 \mathrm{~h})$. 164 
TABELA IV.2: Perfis de alcalinidade a bicarbonato e de ácidos voláteis totais ao longo do ciclo para o ensaio em batelada $(8 \mathrm{~h})$

TABELA IV.3: Perfis de concentração de substrato e eficiência de remoção ao longo do ciclo para o ensaio em batelada alimentada ( $2 \mathrm{~h})$ seguida de batelada $(6 \mathrm{~h})$

TABELA IV.4: Perfis de alcalinidade a bicarbonato e de ácidos voláteis totais ao longo do ciclo para o ensaio em batelada alimentada $(2 \mathrm{~h})$ seguida de batelada $(6 \mathrm{~h})$

TABELA IV.5: Perfis de composição do biogás ao longo do ciclo para o ensaio em batelada alimentada $(2 \mathrm{~h})$ seguida de batelada $(6 \mathrm{~h})$.

TABELA IV.6: Perfis de fração molar do biogás ao longo do ciclo para o ensaio em batelada alimentada $(2$ h $)$ seguida de batelada $(6 \mathrm{~h})$.

TABELA IV.7: Perfis de concentração de substrato e eficiência de remoção ao longo do ciclo para o ensaio em batelada alimentada (4 h) seguida de batelada $(4 \mathrm{~h})$

TABELA IV.8: Perfis de alcalinidade a bicarbonato e de ácidos voláteis totais ao longo do ciclo para o ensaio em batelada alimentada (4 h) seguida de batelada $(4 \mathrm{~h})$.

TABELA IV.9: Perfis de composição do biogás ao longo do ciclo para o ensaio em batelada alimentada $(4 \mathrm{~h})$ seguida de batelada $(4 \mathrm{~h})$. 
TABELA IV.10: Perfis de fração molar do biogás ao longo do ciclo para o ensaio em batelada alimentada (4 h) seguida de batelada $(4 \mathrm{~h})$.

TABELA IV.11: Perfis de concentração de substrato e eficiência de remoção ao longo do ciclo para o ensaio em batelada alimentada (4 h) seguida de batelada (4 h)

TABELA IV.12: Perfis de alcalinidade a bicarbonato e de ácidos voláteis totais ao longo do ciclo para o ensaio em batelada alimentada (4 h) seguida de batelada $(4 \mathrm{~h})$.

TABELA IV.13: Perfis de composição do biogás ao longo do ciclo para o ensaio em batelada alimentada $\left(\begin{array}{ll}6 & \mathrm{~h}\end{array}\right)$ seguida de batelada ( $2 \mathrm{~h})$.

TABELA IV.14: Perfil de fração molar do biogás ao longo do ciclo para o ensaio em batelada alimentada $(6 \quad \mathrm{~h})$ seguida de batelada $(2 \mathrm{~h})$.

TABELA IV.15: Perfis de concentração de substrato e eficiência de remoção ao longo do ciclo para o ensaio em batelada alimentada $(8 \mathrm{~h}) . \mathbf{1 7 8}$

TABELA IV.16: Perfis de alcalinidade a bicarbonato e de ácidos voláteis totais ao longo do ciclo para o ensaio em batelada alimentada ( 8 h). 179

TABELA IV.17: Perfis de composição do biogás ao longo do ciclo para o ensaio em batelada alimentada $(8 \mathrm{~h})$

TABELA IV.18: Perfis de fração molar do biogás ao longo do ciclo para o ensaio em batelada alimentada $(8 \mathrm{~h})$ 
TABELA V.1: Dados obtidos no ajuste cinético com concentração de substrato residual $\left(\mathrm{C}_{\mathrm{SR}}\right)$ experimental e coeficiente cinético aparente $\left(\mathrm{k}_{1}\right)$ estimado pelo modelo. 183

TABELA V.2: Dados obtidos no ajuste cinético com concentração de substrato residual $\left(\mathrm{C}_{\mathrm{SR}}\right)$ e coeficiente cinético aparente $\left(\mathrm{k}_{1}\right)$ estimados pelo modelo. 


\section{LISTA DE ABREVIATURAS E SIGLAS}

ASBR

Reator Anaeróbio Operado em Batelada Seqüencial (Anaerobic Sequencing Batch Reactor).

BAPH Bactérias acetogências produtoras de hidrogênio.

BRN Bactérias Redutoras de Nitrato.

BRS Bactérias Redutoras de Sulfato.

DEQ/UFSCar Departamento de Engenharia Química da Universidade Federal de São Carlos.

DQO Demanda química de oxigênio.

EEM/IMT Escola de Engenharia Mauá do Instituto Mauá de Tecnologia.

EESC/USP Escola de Engenharia de São Carlos da Universidade de São Paulo.

EPR Etileno propileno.

FAPESP $\quad$ Fundação de Amparo à Pesquisa do Estado de São Paulo.

IPH/UFRGS Instituto de Pesquisas Hidráulicas da Universidade Federal do Rio Grande do Sul.

PEC Polímero extracelular.

PCE Percloroetileno.

PVC Cloro polivinil.

UASB Reator Anaeróbio de Fluxo Ascendente e Manta de Lodo (Upflow Anaerobic Sludge Blanket). 


\section{LISTA DE SÍMBOLOS}

$\mathrm{AB} \quad$ Alcalinidade a bicarbonato, $\left(\mathrm{mgCaCO}_{3} / \mathrm{L}\right)$.

AI Alcalinidade intermediária, $\left(\mathrm{mgCaCO}_{3} / \mathrm{L}\right)$.

AP Alcalinidade parcial, $\left(\mathrm{mgCaCO}_{3} / \mathrm{L}\right)$.

AT Alcalinidade total, $\left(\mathrm{mgCaCO}_{3} / \mathrm{L}\right)$.

AVT Concentração de ácidos voláteis totais, (mgHAc/L).

$\mathrm{C}_{\mathrm{AF}}$ Concentração de matéria orgânica filtrada no afluente, (mgDQO/L).

$\mathrm{C}_{\mathrm{AT}}$ Concentração de matéria orgânica total no afluente, (mgDQO/L).

COV Carga orgânica volumétrica, (mgDQO/Ld).

$\mathrm{C}_{\mathrm{S}} \quad$ Concentração de substrato, $(\mathrm{mgDQO} / \mathrm{L})$.

$\mathrm{C}_{\mathrm{SF}} \quad$ Concentração de substrato filtrada, (mgDQO/L).

$\mathrm{C}_{\mathrm{SR}} \quad$ Concentração de substrato residual, (mgDQO/L).

$\mathrm{C}_{\mathrm{ST}}$ Concentração de substrato total, (mgDQO/L).

$\mathrm{C}_{\mathrm{X}} \quad$ Concentração de biomassa, (mgSVT/L).

D Velocidade específica de alimentação, $\left(\mathrm{h}^{-1}\right)$.

F/M Razão substrato/microrganismos.

HAc. Ácido acético.

$\mathrm{k}_{1} \quad$ Parâmetro cinético aparente do modelo de primeira ordem, (1/(h.mgSVT/L)).

$\mathrm{k}_{1}{ }^{\mathrm{B}} \quad$ Parâmetro cinético aparente do modelo de primeira ordem, obtido para fase em batelada, (1/(h.mgSVT/L)).

$\mathrm{k}_{1}{ }^{\mathrm{BA}} \quad$ Parâmetro cinético aparente do modelo de primeira ordem, obtido para fase em batelada alimentada, (1/(h.mgSVT/L)). 
$\mathrm{K}_{\mathrm{S}} \quad$ Constante cinética do modelo proposto por Monod, (mgDQO/L).

pH Potencial hidrogeniônico.

Q Vazão, $\left(\mathrm{m}^{3} / \mathrm{h}\right)$

$\mathrm{R}_{\mathrm{S}} \quad$ Velocidade de consumo de substrato, (mgDQO/L.h).

$\mathrm{r}_{\mathrm{S}} \quad$ Velocidade específica de consumo de substrato (mgDQO/mgSVT.h).

SST Concentração de sólidos suspensos totais, (mg/L).

SSV Concentração de sólido suspensos voláteis, (mg/L).

ST Concentração de sólidos totais, $(\mathrm{mg} / \mathrm{L})$.

SVT Concentração de sólidos voláteis totais, (mg/L).

T Temperatura $\left({ }^{\circ} \mathrm{C}\right)$.

$t_{c} \quad$ Tempo de duração do ciclo (h).

t $_{\mathrm{F}}$ Tempo de duração da batelada alimentada, tempo de duração da alimentação complementar, (min).

$\mathrm{t}_{\mathrm{F}} / \mathrm{t}_{\mathrm{C}} \quad$ Razão tempo de alimentação complementar/tempo de ciclo.

TRC Tempo de residência celular, (d).

TRH Tempo de residência hidráulica, (d).

V Volume de meio no reator (L).

$\mathrm{V}_{\mathrm{ALI}} \quad$ Volume de água residuária alimentado, (L).

$\mathrm{V}_{\mathrm{t}} \quad$ Volume total do reator, (L).

X Quantidade de biomassa no reator, (gSVT).

$\mathrm{Y}_{\mathrm{X} / \mathrm{S}} \quad$ Fator de conversão entre biomassa formada e substrato consumido, (mgSVT/mgDQO).

$\varepsilon \quad$ Eficiência de remoção de matéria orgânica filtrada no reator, $(\%)$.

$\varepsilon_{\mathrm{SF}} \quad$ Eficiência de remoção de substrato filtrada no sistema, $(\%)$. 
$\varepsilon_{\mathrm{ST}} \quad$ Eficiência de remoção de matéria orgânica não filtrada no sistema, (\%).

$\mu \quad$ Velocidade específica de crescimento de biomassa, (mgSVT/ mgSVT. h).

$\mu_{\text {Max }}$ Velocidade específica máxima de crescimento de biomassa, (mgSVT/ mgSVT. h). 


\section{RESUMO}

BORGES, A. C. Influência da estratégia de alimentação no desempenho do reator anaeróbio operado em batelada seqüencial, contendo biomassa imobilizada. São Carlos, 2003. 184p. Dissertação (Mestrado), Escola de Engenharia de São Carlos, Universidade de São Paulo.

Submeteu-se um reator anaeróbio operado em batelada seqüencial a diferentes tempos de enchimento, com o objetivo de verificar-se o desempenho do sistema. O reator, construído em acrílico e com capacidade de 6,3 L, tratou por ciclo um volume de 2,5 L de esgoto sintético com concentração de aproximadamente $500 \mathrm{mgDQO} / \mathrm{L}$. O sistema foi operado à temperatura de $30 \pm 1{ }^{\circ} \mathrm{C}$, com duração de $8 \mathrm{~h}$ para cada ciclo $\left(t_{C}\right)$ e agitação de 500 rpm implementada mecanicamente. Cubos de espuma de poliuretano foram usados como suporte para imobilização da biomassa. No início de cada ciclo, o reator foi carregado com $60 \%$ do volume do esgoto; o restante foi preenchido durante tempos de enchimento $\left(t_{\mathrm{F}}\right)$ que caracterizaram as diferentes estratégias de alimentação. Os resultados obtidos demonstram que para razões $t_{F} / t_{C} \leq 0,5$ o sistema alcança médias de remoção de matéria orgânica acima de $75 \%$ e $70 \%$ para amostras filtradas e não filtradas, respectivamente. Nos ensaios em que $t_{F} / t_{C}>0,5$, registrou-se perda na eficiência e formação de polímeros extracelulares, apesar da estabilidade observada. O estudo contribuiu para o melhor entendimento do sistema e definição de técnicas de operação em futuras aplicações.

Palavras-chave: tratamento anaeróbio, reator operado em batelada seqüencial, ASBR, estratégia de alimentação, biomassa imobilizada. 


\begin{abstract}
BORGES, A. C. Influence of feeding strategy on the performance of anaerobic sequencing batch reactor containing immobilized biomass. São Carlos, 2003. 184p. Dissertação (Mestrado), Escola de Engenharia de São Carlos, Universidade de São Paulo.
\end{abstract}

An anaerobic sequencing batch reactor was operated at different fill times with the objective to asses system performance. The reactor, made of plexiglas and with a capacity of $6.3 \mathrm{~L}$, treated per cycle $2.5 \mathrm{~L}$ of synthetic wastewater with a concentration of nearly $500 \mathrm{mgCOD} / \mathrm{L}$. The system was operated at a temperature of $30 \pm 1{ }^{\circ} \mathrm{C}$, with $8 \mathrm{~h}$ cycles $\left(\mathrm{t}_{\mathrm{C}}\right)$ and mechanical agitation rate of $500 \mathrm{rpm}$. Cubic particles of polyurethane foam were used as support material for anaerobic biomass immobilization. At the start of each cycle, the reactor was fed with $60 \%$ of the wastewater volume, the remainder was filled at different feeding times $\left(t_{F}\right)$ that characterized the different feeding strategies. The results obtained showed that for a ratio of $t / t_{C} \leq 0.5$ the system attained average filtered and non-filtered substrate removal efficiency of $75 \%$ and $70 \%$, respectively. Ratios of $t_{F} / t_{C}>0.5$, resulted in loss in efficiency and formation of extra cellular polymers, in spite of system stability. The study contributed to a better understanding of the system and definition of operational techniques for future applications.

Keywords: anaerobic treatment, sequencing batch reactor, ASBR, feeding strategy, immobilized biomass. 


\section{CAPÍtULO 1 INTRODUÇÃO}

$\mathrm{O}$ aumento do número de pesquisas relacionadas ao processo da digestão anaeróbia vem provocando mudanças na concepção dos sistemas de tratamento de águas residuárias. Configurações inovadoras vêm sendo estudadas, com o objetivo de se obter sistemas simplificados e mais eficientes, conjugando baixos custos e simplicidade operacional. Tal fato se deve ao desenvolvimento dos chamados sistemas de alto desempenho, caracterizados pela capacidade de retenção de grandes quantidades de biomassa e pela elevada atividade microbiana, mesmo com a imposição de baixos tempos de residência hidráulica. Nesse sentido, merece destaque o uso de células imobilizadas, na forma de grânulos ou biofilme aderido a suporte inerte. O conhecimento sobre mecanismos de retenção de biomassa e estrutura de biofilmes é sem dúvida, decorrente de um melhor entendimento do processo biológico nos reatores.

O desenvolvimento de configurações de reatores anaeróbios, com ênfase em estudos de aspectos fundamentais buscando a definição de parâmetros para aumento de escala e projeto, é objetivo do projeto temático "Desenvolvimento, análise, aprimoramento e otimização de reatores anaeróbios para tratamento de águas 
residuárias". Esse trabalho, financiado pela FAPESP, é realizado pela Escola de Engenharia de São Carlos/USP, pelo Departamento de Engenharia Química/UFSCar e pela Escola de Engenharia Mauá/IMT. O reator anaeróbio operado em batelada seqüencial (ASBR) é uma das configurações estudadas dentro do escopo do projeto.

O ASBR, desenvolvido inicialmente por grupos de trabalho da Universidade do Estado de Iowa (Estados Unidos) e da Universidade de Ottawa (Canadá), apresenta-se como alternativa aos reatores contínuos para várias aplicações, podendo ser usado por exemplo, como sistema de tratamento em indústrias que trabalhem com padrões de emissão muito restritivos ou com compostos de difícil degradação e fábricas que lancem efluentes de forma intermitente. Entretanto, a ampliação da escala de trabalho depende ainda do entendimento de vários aspectos fundamentais e tecnológicos do processo, como por exemplo as relações entre desempenho do sistema e variáveis físicas e bioquímicas.

O emprego de um suporte para imobilização da biomassa em reatores anaeróbios operados em batelada seqüencial propicia a melhora na retenção de sólidos e a eliminação da sedimentação, uma das fases do processo. Em contrapartida, questões relacionadas à transferência de massa são levantadas, uma vez que o processo envolve fases distintas: sólida e líquida.

Registram-se diversos estudos sobre fatores que afetam o rendimento global do ASBR. Pesquisas enfocando a influência da implementação de agitação, da razão concentração de substrato/concentração de biomassa, além de trabalhos sobre diferentes configurações para o reator, têm sido relatadas, sobretudo em sistemas com biomassa auto-imobilizada. Todavia, estudos sobre a estratégia de alimentação, 
uma das principais características operacionais do sistema são ainda escassos na literatura.

A possibilidade da implementação de tempos de enchimento mais longos em relação ao tempo total de cada ciclo vislumbra na prática a diminuição dos volumes dos tanques de equalização, obrigatórios em situações onde não há garantia de carregamento nas ocasiões previstas em projeto. A mobilidade operacional, oriunda da possibilidade de adoção de diferentes tempos para o carregamento do reator, também pode ser citada como fator motivador do estudo da batelada alimentada.

Dessa maneira, propôs-se a avaliação do desempenho de um ASBR tratando esgoto sintético, quando submetido a diferentes condições de carregamento. O estudo contribuiu para o melhor entendimento desse aspecto fundamental e para o estabelecimento de bases para a aplicação dessa tecnologia em escala plena. 


\section{CAPÍtULO 2}

\section{OBJETIVOS}

O trabalho objetivou a avaliação operacional de um reator anaeróbio operado em batelada alimentada seqüencial contendo biomassa imobilizada e agitado mecanicamente, quando submetido a diferentes estratégias de alimentação. Foram estabelecidos, ainda, os seguintes objetivos específicos:

(i) Avaliação da eficiência do reator, levando-se em consideração a remoção de matéria orgânica.

(ii) Monitoramento da estabilidade do sistema, quando submetido a diferentes períodos de carregamento.

(iii) Avaliação da influência da razão concentração de substrato/ concentração de microrganismos nos diferentes ensaios propostos.

(iv) Estimativa das constantes cinéticas aparentes para os experimentos realizados.

(v) Comparação dos resultados com os dados obtidos por RATUSZNEI et al. (2003) e estabelecimento de conclusões sobre os protocolos experimentais utilizados. 


\section{CAPÍtULO 3}

\section{REVISÃO BIBLIOGRÁFICA}

\subsection{Noções de qualidade e poluição das águas}

Elemento insubstituível nas mais diversas atividades do homem, a água representa insumo fundamental à vida, sendo, ainda, componente da paisagem e do meio ambiente. Dada sua utilidade, a água é considerada um recurso finito, escasso e de valor econômico. Segundo FREITAS \& SANTOS (1999), “a água é um recurso natural essencial, seja como componente bioquímico de seres vivos, como meio de vida de várias espécies vegetais e animais, como elemento representativo de valores sociais e culturais e até como fator de produção de vários bens de consumo final e intermediário". Problemas como a degradação da qualidade das águas e o recrudescimento de enfermidades ligadas ao saneamento são desafios para a engenharia sanitária neste início de século.

Os esgotos, industriais e domésticos, estão entre as principais fontes de poluição dos corpos d'água e sabe-se que apenas $0,78 \%$ da água disponível no planeta pode ser realmente utilizada para abastecimento público. Portanto, sendo o saneamento básico importante ferramenta sócio-econômica no desenvolvimento de uma sociedade, justifica-se os esforços no intuito da implantação no país de uma 
infra-estrutura sanitária que certamente proporcionará melhorias na qualidade de vida de nossa população.

O lançamento de esgotos brutos em corpos receptores naturais ou a sua disposição no solo foram e ainda são alternativas empregadas de forma muito intensa. Dependendo da carga orgânica lançada, o meio recebe e decompõe os contaminantes até alcançar um nível que não cause problemas ou alterações prejudiciais ao ecossistema local (ANDRADE NETO \& CAMPOS, 1999). Define-se dessa maneira a autodepuração dos corpos d'água, que está vinculada ao restabelecimento do equilíbrio no meio aquático, por mecanismos essencialmente naturais, após as alterações induzidas pelos despejos afluentes. Esse fenômeno, caracterizado basicamente pela conversão de matéria orgânica em produtos mineralizados inertes, apresenta em seu conceito a mesma relatividade dos conceitos de qualidade e poluição: uma água pode ser considerada depurada, sob um ponto de vista, mesmo que não esteja totalmente purificada em termos higiênicos, apresentando, por exemplo, organismos patogênicos (von SPERLING, 1996).

Os processos de tratamento de esgotos são condicionamentos aplicados para que o corpo d'água receptor não sofra alterações nos parâmetros de qualidade fixados para a região afetada pelo lançamento (PESSÔA \& JORDÃO, 1982), e diante do enorme déficit sanitário brasileiro, aliado ao perfil sócio-econômico de nossas comunidades, constata-se a necessidade por sistemas simplificados de coleta e tratamento de esgotos. Esses sistemas devem ser sustentáveis, conjugando baixos custos de implantação e de operação e simplicidade operacional (CHERNICHARO, 1994). 


\subsection{Fundamentos do tratamento anaeróbio}

\subsubsection{A digestão anaeróbia}

A tecnologia anaeróbia para o tratamento de águas residuárias pode ser considerada, segundo FORESTI et al. (1999), recente, pois vem sendo utilizada de forma sistemática há pouco mais de cem anos; contudo, sabe-se que o uso de microrganismos anaeróbios remota à antiguidade: muitas civilizações antigas produziram bebidas e alimentos que, atualmente sabemos, são produtos da fermentação microbiana (PELCZAR Jr et al., 1996).

De acordo com MOSEY (1983), “a digestão anaeróbia é um processo biológico natural que ocorre na ausência de oxigênio molecular, no qual populações bacterianas interagem estreitamente para promover a fermentação estável e auto-regulada da matéria orgânica, da qual resultam, principalmente, os gases metano $\left(\mathrm{CH}_{4}\right)$ e dióxido de carbono $\left(\mathrm{CO}_{2}\right)$ "). Associações simbióticas, de modo direto ou indireto, entre vários grupos de microrganismos descrevem esse processo de conversão (HARPER \& POHLAND, 1986).

O entendimento do processo da digestão anaeróbia é de grande importância no desenvolvimento de sistemas mais eficientes no tratamento de efluentes e nesse sentido observa-se a necessidade da manutenção do caráter multidisciplinar da engenharia sanitária. Para LETTINGA (1994), o conhecimento e a compreensão dos aspectos fundamentais da tecnologia de tratamento anaeróbio, especialmente da bioquímica e da microbiologia da digestão anaeróbia, são essenciais para o projeto correto e aplicação desses sistemas. 
HARPER \& POHLAND (1986) descreveram as nove etapas reconhecidas do processo, cada qual mediada por um grupo específico de microrganismos, a saber:

i. Hidrólise de polímeros orgânicos complexos, como proteínas, carboidratos e lipídeos, em seus respectivos monômeros: aminoácidos, açúcares e ácidos graxos.

ii. Conversão de monômeros orgânicos a hidrogênio, bicarbonato, ácido acético, ácido propiônico, ácido butírico e outros produtos orgânicos, tais como o etanol e o ácido lático. Esta etapa, denominada acidogênese é realizada por um grupo diversificado de bactérias, das quais a maioria é anaeróbia obrigatória. Contudo algumas espécies acidogênicas são facultativas e podem metabolizar material orgânico por via oxidativa.

iii. Acetogênese: oxidação de produtos orgânicos reduzidos a hidrogênio, bicarbonato e ácido acético pelas bactérias acetogênicas produtoras de hidrogênio (BAPH).

iv. Respiração homoacetogênica do bicarbonato pelas bactérias homoacetogênicas, com formação de acetato.

v. Oxidação de produtos orgânicos reduzidos a acetato pelas bactérias redutoras de nitrato (BRN) e pelas bactérias redutoras de sulfato (BRS).

vi. Oxidação de acetato a bicarbonato pelas BRN E BRS.

vii. Oxidação de hidrogênio pelas BRN e BRS.

viii. Fermentação metanogênica acetoclástica: as arqueas metanogênicas acetoclásticas convertem o acetato produzido nas etapas anteriores em gás metano e dióxido de carbono. 
ix. Respiração metanogênica do hidrogênio: arqueas metanogênicas hidrogenotróficas realizam a respiração do $\mathrm{H}$, utilizando-o na produção de $\mathrm{CH}_{4}$.

A Figura 3.1 ilustra as etapas do processo da digestão anaeróbia.

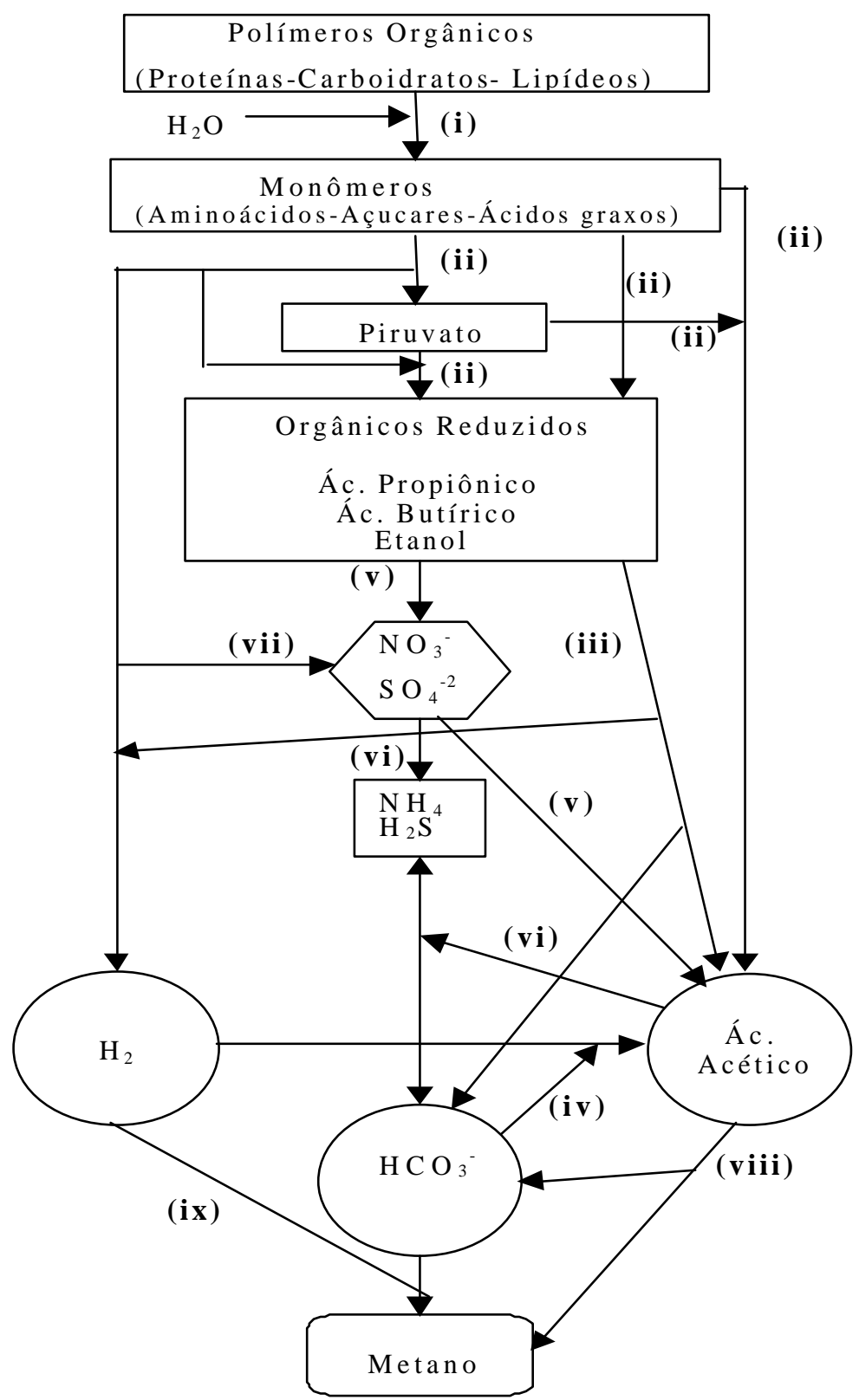

FIGURA 3.1: Representação esquemática do processo metabólico da digestão anaeróbia. Fonte: HARPER \& POHLAND (1986). 
Responsáveis pela metanogênese, etapa final da digestão anaeróbia, os microrganismos do domínio Arquea são considerados únicos, com propriedades metabólicas extraordinárias e filogenia particular: apesar da organização celular procariótica, são organismos evolutivamente distintos das bactérias (domínio Bactéria). Amplamente distribuídas na natureza em ambientes anóxicos, as arqueas metanogênicas apresentam vias bioquímicas raras, produzindo gás metano através de sistemas enzimáticos. Provavelmente, a característica mais evidente das metanogênicas está relacionada com sua especificidade de substratos para crescimento e produção de metano (VAZOLLER et al., 1999). Quanto à sensibilidade ao oxigênio, estudos recentes revelam uma alta tolerância, particularmente por parte dos microrganismos presentes no lodo de unidades de tratamento (KATO et al., 1997).

De acordo com Figura 3.1, fica claro que a formação do gás metano como produto final da digestão anaeróbia depende da existência, em proporções que permitam o equilíbrio do processo, de populações de microrganismos com funções metabólicas distintas e específicas.

Segundo FORESTI et al. (1999), para um bom desempenho dos reatores anaeróbios é imprescindível que os compostos orgânicos sejam convertidos em precursores imediatos de metano. Caso essa conversão não aconteça, a metanogênese não ocorrerá, acarretando no acúmulo dos produtos da fase de hidrólise e fermentação no reator. O entendimento dos aspectos termodinâmicos da digestão anaeróbia resultou na elucidação de alguns mecanismos de autocontrole do processo. Contudo, ressalta-se que os estudos de transferência de energia que ocorrem em reatores anaeróbios são por si só complexos, além de envolver a determinação 
quantitativa de produtos intermediários e finais que estão presentes no meio em concentrações muito baixas (FORESTI et al., 1999).

\subsubsection{Fatores importantes na digestão anaeróbia}

BENEFIELD \& RANDALL (1980) afirmam que conhecimentos sobre as necessidades nutricionais da microflora e sobre os fatores ambientais que afetam o crescimento microbiano são necessários na concepção, projeto e operação de sistemas biológicos de tratamento. No processo da digestão anaeróbia, fatores como a capacidade de assimilação de cargas tóxicas e a atividade metanogênica também desempenham um importante papel e devem ser considerados.

\section{Temperatura}

As alterações na velocidade do metabolismo dos microrganismos, no equilíbrio iônico e na solubilidade dos substratos são alguns dos efeitos da temperatura na digestão anaeróbia. Três faixas aproximadas de temperatura podem ser associadas ao crescimento microbiano nos processos biológicos: faixa psicrofílica (0 a $20^{\circ} \mathrm{C}$ ), mesofílica $\left(20\right.$ a $45^{\circ} \mathrm{C}$ ) e termofílica (acima de $45{ }^{\circ} \mathrm{C}$ ), e dois níveis ótimos de temperatura têm sido encontrados na literatura, um na faixa mesofílica (30 a $35{ }^{\circ} \mathrm{C}$ ) e outro na faixa termofílica $\left(50\right.$ a $\left.55^{\circ} \mathrm{C}\right)$. Devido às condições climáticas, a maioria dos reatores têm sido projetada na faixa mesofílica, entretanto, pesquisas e projetos de sistemas operados em diversas temperaturas vêm sendo conduzidos nos últimos anos. 


\section{pH, alcalinidade e ácidos voláteis}

Igualmente importantes, esses fatores ambientais estão intimamente relacionados entre si. Nos sistemas anaeróbios de tratamento, o pH é afetado principalmente pela concentração de ácidos carbônicos e ácidos voláteis; na faixa de pH entre 6,0 e 7,5 o tamponamento (capacidade de uma solução em evitar mudanças no $\mathrm{pH}$ ) depende basicamente do sistema formado pelo gás carbônico e alcalinidade (CHERNICHARO, 1994). O pH, que afeta a atividade enzimática e as concentrações de toxicidade de vários compostos, deve ser mantido, segundo SPEECE (1996), entre 6,5 e 8,2 na operação de um reator anaeróbio.

\section{Nutrientes}

Todos os processos biológicos empregados na engenharia ambiental têm sua base na necessidade nutricional dos microrganismos (BENEFIELD \& RANDALL, 1980). Nitrogênio, fósforo e enxofre são considerados essenciais para a metanogênese. Geralmente a relação DQO:N:P de 500:5:1 é suficiente para as necessidades de macronutrientes dos microrganismos anaeróbios (SPEECE, 1996) e segundo FORESTI et al. (1999), a concentração de enxofre deve ser da mesma ordem de grandeza ou levemente superior à de fósforo. Além desses nutrientes, um grande número de outros elementos, denominados micronutrientes, tem se mostrado necessário ao processo da digestão anaeróbia (SINGH et al., 1999). PFEFFER (1979) afirma que as águas residuárias municipais usualmente contêm todos os nutrientes requeridos em quantidades suficientes, mas outros substratos, como os esgotos industriais, podem não possuir a quantidade requerida e usualmente 
necessitam de uma suplementação de nutrientes para uma degradação ótima no processo.

\section{Assimilação de cargas tóxicas}

A toxicidade tem sido considerada um dos principais motivos da não utilização da digestão anaeróbia: durante décadas difundiu-se o conceito equivocado que o processo seria extremamente sensível a cargas tóxicas que provocariam o colapso dos reatores. A sensibilidade a cargas tóxicas depende significativamente da idade do lodo: longos tempos de retenção celular são a melhor salvaguarda contra a presença de compostos tóxicos (PARKIN et al., 1983). De um modo geral, os produtos possivelmente tóxicos normalmente não se encontram no esgoto sanitário; quanto às águas residuárias industriais, a literatura já registra um grande número de trabalhos com o objetivo de elucidar o mecanismo de ação dos compostos tóxicos (SPEECE, 1996).

\subsection{A disseminação da tecnologia anaeróbia no tratamento de águas residuárias}

FORESTI (1994) afirma que a análise do histórico da aplicação de unidades anaeróbias no tratamento de águas residuárias permite constatar a lenta evolução ocorrida no entendimento do processo anaeróbio, desde o final do século XIX até os dias de hoje. 
Segundo McCARTY (1982), a primeira contribuição significativa ao tratamento anaeróbio dos sólidos em suspensão presentes em esgotos sanitários foi a câmara vedada ao ar, desenvolvida na França em 1882 e denominada Fossa Automática Mouras. Recebido com grande entusiasmo pelos técnicos da época, esse sistema diferenciava-se de outras fossas utilizadas por serem completamente vedados os acessos de ar no seu interior. A câmara fechada ao ar permitia que o material em suspensão presente nos esgotos fosse liquefeito. Outras unidades, baseadas na Fossa Mouras, foram então desenvolvidas como o Tanque Talbot nos Estados Unidos, em 1894, o Tanque Séptico na Inglaterra, em 1895 e o Tanque Imhoff na Alemanha, em 1905.

O tanque Imhoff provocou a redução dos custos de disposição de lodos e rapidamente tornourse bem sucedido, principalmente nos Estados Unidos. Contudo, apesar do melhor desempenho que os tanques sépticos, os tanques Imhoff ainda apresentavam alguns problemas: eram profundos, sendo que o tanque de digestão era intimamente conectado ao de sedimentação. A instalação de um sistema de aquecimento de lodo em digestor separado solucionou o problema, proporcionando uma eficiência maior que a dos tanques Imhoff; o aquecimento dos tanques de digestão passou a ser feito utilizando-se o metano produzido pelo processo, e a partir daí, o sistema cresceu rapidamente em popularidade (McCARTY, 1982).

Ao final dos anos 30, já havia um conhecimento acumulado razoável do processo para permitir a sua aplicação prática no tratamento de lodos de esgotos em digestores aquecidos, uma vez que numerosos estudos realizados nos anos anteriores levaram ao melhor entendimento da importância da inoculação e do controle do pH em sistemas anaeróbios. O desenvolvimento significativo da tecnologia anaeróbia, 
porém, só ocorreu nos anos 50, quando a necessidade da manutenção de altas concentrações de microrganismos nos digestores e de um contato eficiente entre a biomassa e a água residuária foi reconhecida. IZA et al. ${ }^{1}$ apud NDON \& DAGUE (1997a), afirma que a idéia da captura de sólidos com subsequiente recirculação no reator foi usada no desenvolvimento de um reator que ficaria conhecido como Processo Anaeróbio de Contato.

A partir do final da década de 60, após o pioneiro trabalho de Young e McCarty no desenvolvimento de filtros anaeróbios ascendentes, o processo anaeróbio ampliou sua perspectiva de aplicação e desde então várias configurações de reatores de alta eficiência vêm sendo desenvolvidas.

A maioria das configurações propostas para reatores anaeróbios ao longo dos últimos anos tem se mostrado eficiente no tratamento de águas residuárias. $\mathrm{O}$ desenvolvimento dos sistemas de alto desempenho se deve ao incremento de pesquisas na área de tratamento anaeróbio de águas residuárias; estes sistemas caracterizam-se pela capacidade de retenção de grandes quantidades de biomassa e pela elevada atividade, mesmo com a imposição de baixos tempos de residência hidráulica.

Segundo ZAIAT et al. (2001), “a tendência do uso do reator anaeróbio como principal unidade de tratamento biológico deve-se principalmente à constatação de que fração considerável da matéria orgânica pode ser removida, nessa unidade, sem o dispêndio de energia, com menor produção de lodo de excesso e a possibilidade de

${ }^{1}$ IZA, J.; COLLERAM, E.; PARIS, J.M.; WU, W.M. (1991). International workshop on anaerobic treatment technology for municipal and industrial wastewaters: summary paper. Water Science and Technology, 24, pp.1-16. 
recuperação e utilização do gás metano como combustível”.

A concepção e disseminação do uso do reator anaeróbio de manta de lodo, conhecido como UASB (Upflow Anaerobic Sludge Blanket) é responsável pelo crescimento da aplicação dos sistemas anaeróbios como principal unidade de tratamento: as demais unidades de pós-tratamento passam a ser responsáveis pela remoção da parcela da fração remanescente de matéria orgânica, de forma a permitir que os padrões de emissão de efluentes sejam atingidos (FORESTI et al., 1999). Embora SPEECE (1996) relate registros de sistemas anaeróbios atingindo níveis secundários de padrão de emissão, deve-se lembrar que a digestão anaeróbia somente converte material orgânico: outros constituintes importantes do esgoto, em particular nutrientes e patogênicos, não são afetados de maneira significativa pelo tratamento anaeróbio (van HAANDEL \& LETTINGA, 1994; CHERNICHARO et al., 2001).

Para esgoto sanitário, a aplicação de reatores anaeróbios como principal unidade de tratamento teve início na década de 80, principalmente na Holanda, Brasil, Colômbia, Índia e México. Com exceção da Holanda, é sintomático que os países interessados na aplicação do processo anaeróbio sejam nações em desenvolvimento, nas quais o clima é favorável à operação de reatores à temperatura ambiente (FORESTI et al., 1999). Em relação às barreiras ao desenvolvimento dos reatores anaeróbios, POHLAND (1998) afirma que o número e a variedade de sistemas de tratamento em escala plena vêm crescendo desde que a tecnologia foi introduzida como rotina para o gerenciamento de lodo em estações de tratamento municipais, apesar da história de ceticismo, de oposição ao uso e de preferência por outros sistemas. 
Atualmente, diferentes configurações de reatores anaeróbios vêm sendo estudadas, e concepções inovadoras têm surgido com aplicações promissoras, como é o caso do reator anaeróbio operado em batelada sequiencial, foco do presente trabalho.

\subsection{Reator anaeróbio operado em batelada seqüencial - ASBR}

\subsubsection{Introdução}

Em trabalhos de 1966 e 1970, os pesquisadores americanos Dague, McKinney e Pfeffer observaram que a biomassa anaeróbia floculava de maneira análoga ao sistema de lodos ativados aeróbio, e que a eficiência da floculação era afetada pela carga orgânica, particularmente pela razão substrato/microrganismos. Nesses estudos foram investigados os efeitos da biofloculação na sedimentabilidade do lodo e a retenção em sistemas anaeróbios. Os reatores usados foram operados em batelada, com separação de sólidos ocorrendo no sistema antes da descarga do sobrenadante como efluente; com a sedimentação interna, mostrour-se que o processo em batelada era capaz de separar o tempo de residência celular do tempo de residência hidráulica. O processo foi chamado de Lodo Ativado Anaeróbio (DAGUE et al. 1992; NDON \& DAGUE, 1997a).

Considerando esses estudos, grupos de trabalho da Universidade do Estado de Iowa (Estados Unidos) e da Universidade de Ottawa (Canadá) desenvolveram no final da década de 80 um novo reator de alto desempenho, conhecido como reator 
anaeróbio operado em batelada seqüencial (Anaerobic Sequencing Batch Reactor $A S B R$ ). O processo, patenteado pelo grupo americano em 1993, apresenta grandes vantagens e potencial de utilização em escala plena, sendo portanto uma alternativa aos sistemas contínuos para várias aplicações (NG, 1988; KENNEDY et al., 1991; DAGUE et al., 1992; FERNANDES et al., 1993; BRITO et al., 1997).

No Brasil, os reatores ASBR vêm sendo estudados por grupos da Escola de Engenharia de São Carlos da Universidade de São Paulo (EESC/USP), da Escola de Engenharia Mauá do Instituto Mauá de Tecnologia (EEM/IMT) e do Instituto de Pesquisas Hidráulicas da Universidade Federal do Rio Grande do Sul (IPH/UFRGS). Nessas instituições, os projetos têm enfoque no estudo da otimização do processo ASBR convencional e de novas propostas de configurações de reatores, para que a aplicação do sistema operado em batelada seqüencial em escala plena se torne viável.

\subsubsection{Princípio de funcionamento}

Um ciclo típico do reator anaeróbio operado em batelada compreende quatro etapas: (i) alimentação; (ii) tratamento propriamente dito, por meio das reações ou biotransformações dos constituintes do esgoto por microrganismos; (iii) sedimentação; (iv) descarga, com retirada do líquido tratado e clarificado. A Figura 3.2 ilustra as etapas do processo. 


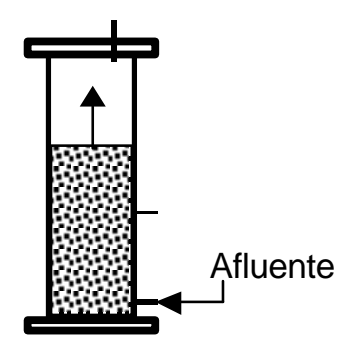

Alimentação

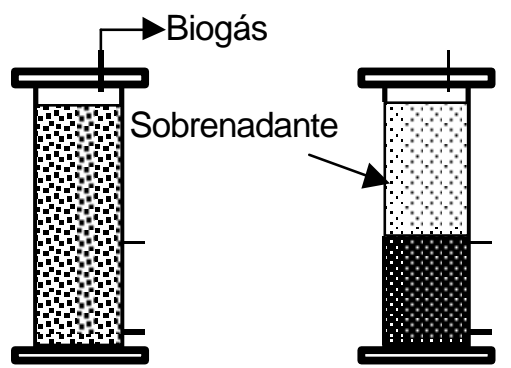

Sedimentação

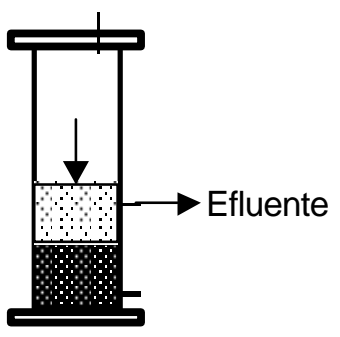

Descarga

FIGURA 3.2: Etapas de operação de um reator anaeróbio operado em batelada seqüencial. Fonte: DAGUE et al. (1992).

A alimentação consiste na adição de um volume predeterminado de água residuária; nessa etapa a concentração de matéria orgânica dentro do reator aumenta rapidamente e as velocidades metabólicas atingem seus valores máximos, proporcionando o melhor contato possível entre o substrato e os microrganismos. $\mathrm{Na}$ fase de reação a matéria orgânica é convertida a biogás e em seguida temr se a sedimentação final do lodo biológico: etapa em que o reator funciona como um clarificador, permitindo a separação dos sólidos e do efluente líquido. Por fim, é feita a descarga do reator, sendo que o volume descartado é normalmente igual ao volume alimentado. Após o esvaziamento do tanque e retirada do líquido tratado, o reator está pronto para repetir a operação com uma nova batelada.

No processo em batelada, a alta razão substrato/microrganismos no início do ciclo de operação resulta em uma velocidade de reação elevada, além de uma grande produção de biogás. Em contraponto, a baixa concentração de substrato próxima ao fim da batelada proporciona condições ideais para a floculação da biomassa e a separação dos sólidos. Essa alternância entre condições de fartura e escassez de substrato no ASBR, visualizada na Figura 3.3, é considerada a característica 
fundamental do processo (DAGUE et al., 1992; SCHMIDT \& DAGUE, 1993; KATO et al., 1999).

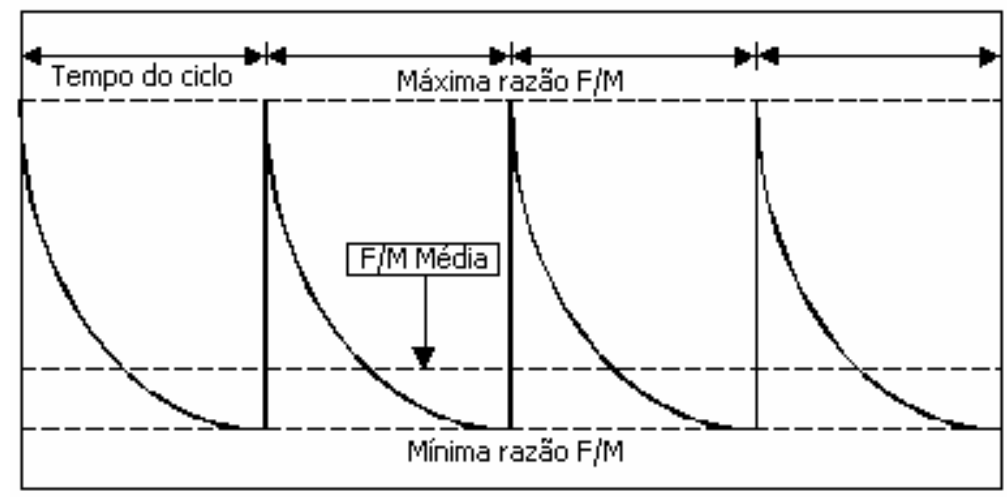

FIGURA 3.3: Efeito da alimentação em batelada na concentração de substrato e na razão F/M. Fonte: DAGUE et al. (1992).

\subsubsection{Vantagens e aplicações}

Diversas vantagens podem ser atribuídas aos sistemas anaeróbios operados em batelada para tratamento de águas residuárias, como melhor controle da qualidade do efluente, alta eficiência de remoção da matéria orgânica e operação simples e estável do sistema.

Comparado com um reator semelhante de alimentação contínua, em geral o volume requerido para o tanque é maior; no entanto, no reator operado em batelada não há necessidade da existência de sedimentador em separado e de recirculação externa de lodo biológico.

Apesar de apresentar muitas vantagens, este tipo de biorreator é deficiente em métodos estabelecidos e técnicas de operação bem definidas; sabe-se que o desenvolvimento e o estudo de reatores anaeróbios operados em batelada ainda é 
muito recente e os resultados obtidos até o momento podem ser considerados apenas indicativos e não conclusivos (ZAIAT et al., 2001). Ocorrência de zonas mortas, alto tempo de decantação, arraste de sólidos e inibição devido a sobrecargas são alguns dos problemas que afetam o desempenho do tratamento. Pesquisas sobre variáveis de influência como agitação e estratégia de alimentação contribuirão para o melhor entendimento do processo.

Grupos de pesquisa de diversos países têm se dedicado ao estudo do reator anaeróbio operado em batelada seqüencial, com aplicações variadas. Além dos esgotos sanitários, vários efluentes industriais podem ser tratados pela via anaeróbia: resíduos de laticínios, abatedouros e frigoríficos, cervejarias, curtumes, produção de álcool e de amido, processamento de batatas, café, frutas e peixes são alguns dos exemplos encontrados na literatura.

A aplicação de sistemas em batelada em tratamento anaeróbio de águas residuárias é particularmente apropriada para os seguintes casos (ZAIAT et al., 2001):

- Indústrias que lançam efluentes de forma intermitente ou atividades que produzam efluentes apenas em algumas épocas do mês ou do ano;

- Indústrias que trabalham com padrões de emissão muito restritivos ou com compostos de difícil degradação, nos quais a qualidade do efluente pode ser controlada lançando-o no ambiente apenas quando os padrões forem atingidos ou quando os eventuais compostos tóxicos presentes tenham sido satisfatoriamente degradados; 
- Sistemas que visam o reuso de águas residuárias ou de substâncias nelas presentes, pois o controle sobre a reutilização das águas pode ser maior e melhor do que em sistemas contínuos;

- Em trabalhos fundamentais que visem a elucidação de alguns fenômenos da degradação anaeróbia, devido à facilidade de instrumentação e controle.

A Tabela 3.1 resume dados experimentais obtidos na operação de reatores anaeróbios operados em batelada seqüencial, em escala de bancada.

TABELA 3.1: Dados experimentais obtidos em ASBRs

\begin{tabular}{|c|c|c|c|c|c|c|c|c|}
\hline Água residuária & $\mathbf{V}_{\mathrm{T}}^{(a)}$ & $\mathbf{T}^{(b)}$ & $\mathbf{t}_{\mathbf{C}}^{(c)}$ & $\mathbf{T R H}^{(a)}$ & $\mathrm{COV}^{(e)}$ & $\mathbf{C}_{\mathrm{AT}}^{(f)}$ & $\varepsilon_{\mathrm{SF}}^{(g)}$ & Referência \\
\hline Chorume de aterro sanitário & 12 & 35 & 6 & $12-48$ & $1,6-3,5$ & $1,1-3,5$ & 90 & HOLLOPETER \& DAGUE (1994) \\
\hline Digestão de lodo de ETE & 4 & 35 & $72-96$ & 240 & $1,1-2,2$ & 15,5 & 95 & CHANG et al. (1994) \\
\hline Leite desnatado em pó & 11,5 & 35 & 6 & 24 & $4-10$ & $0,4-1$ & $70-95$ & REYES III \& DAGUE (1995) \\
\hline Sacarose & 13 & 35 & 4 & 12 & - & $3-9,5$ & $78-95$ & ANGENENT \& DAGUE (1995) \\
\hline Leite desnatado em pó & 12 & 35 & 6 & $12-48$ & $2-12$ & $2-12$ & $90-99$ & SUNG \& DAGUE (1995) \\
\hline Suinocultura & 40 & 20 & 1344 & - & $0,8-1,6$ & 57 & $84-93$ & MASSÉ et al. (1996) \\
\hline Suinocultura & 25 & 20 & 1344 & - & $0,7-1,2$ & 74-94 & $85-96$ & MASSÉ et al. (1997) \\
\hline Leite desnatado em pó & 6 & $15-35$ & 4 & $12-48$ & - & $0,4-1$ & $82-99$ & NDON \& DAGUE $(1997 a, b)$ \\
\hline Leite desnatado em pó & 6 & $5-25$ & - & $6-24$ & 2,4 & 0,6 & $62-90$ & DAGUE et al. (1998) \\
\hline Chorume de aterro sanitário & 2 & 35 & - & $36-240$ & $0,4-9,4$ & $3,8-15,9$ & $64-85$ & TIMUR \& ÖZTURK (1999) \\
\hline Água residuária sintética & 12 & 35 & 12 & 20 & - & 0,4 & 85 & CYBIS \& PESCADOR (2000) \\
\hline Água residuária sintética & 2,5 & 30 & 8 & 8 & 1,5 & 0,5 & $78-92$ & RATUSZNEI et al. (2001) \\
\hline Água residuária de matadouro & 42 & $20-30$ & $20-30$ & $24-84$ & $2,8-4,9$ & 10,5 & 92 & MASSÉ \& MASSE (2001) \\
\hline Água residuária de vinícola & 5 & 35 & - & 52,8 & 8,6 & 19,7 & 98 & RUIZ et al. (2001) \\
\hline $\begin{array}{l}{ }^{(a)} \text { Volume total do reator (L). } \\
{ }^{(b)} \text { Temperatura }\left({ }^{\circ} \mathrm{C}\right) . \\
{ }^{(c)} \text { Tempo do ciclo (h). } \\
{ }^{(d)} \text { Tempo de residência hidráu } \\
{ }^{(e)} \text { Carga orgânica volumétrica } \\
{ }^{(f)} \text { Concentração de matéria or } \\
{ }^{(g)} \text { Eficiência de remoção de m }\end{array}$ & $\begin{array}{l}\mathrm{ca}(\mathrm{h}) \\
\text { gDQ } \\
\text { inica }\end{array}$ & $\begin{array}{l}\text { L.d). } \\
\text { luente }\end{array}$ & & & & & & \\
\hline
\end{tabular}




\subsection{Estudo das variáveis de influência na operação de um ASBR}

\subsubsection{Introdução}

A literatura registra trabalhos com o enfoque na otimização do processo em batelada, através do entendimento de variáveis de influência na operação dos reatores. Paralelamente, novas abordagens para o desenvolvimento dos sistemas anaeróbios intermitentes vêm sendo apresentadas ao longo dos últimos anos. HIRL \& IRVINE (1996) empregaram a recirculação de gás na redução de cloro de percloroetileno (PCE); WELPER et al. (1997) propuseram um sistema termofílico/mesofílico, com dois reatores operando em série, no tratamento de água residuária de alta carga, obtendo uma remoção média de $95 \%$ da carga orgânica solúvel. Outra aplicação interessante foi apresentada por NDON \& RANDALL (1999), que promoveram uma aeração periódica em um ASBR para o tratamento de compostos poli-halogenados; já RATUSZNEI et al. (2000) apresentaram um reator anaeróbio agitado, utilizando espuma de poliuretano para imobilização da biomassa.

Quanto à aplicação em escala plena, registra-se o trabalho realizado por ANGENENT et al. (2002), que estudando a dinâmica populacional da comunidade metanogência durante a partida de um ASBR tratando resíduos de uma fazenda de gado suíno reportaram a viabilidade da operação em escalas maiores (o volume do reator estudado corresponde a $600 \mathrm{~m}^{3}$ ), ressaltando-se os cuidados no monitoramento dos ácidos voláteis totais e da concentração de amônia total.

Para a disseminação da tecnologia e a melhor compreensão do processo observa-se a necessidade de comparação com os sistemas contínuos, predominantes 
hoje em todo mundo. Assim sendo, tornou-se necessário o uso de parâmetros estabelecidos no tratamento de águas residuárias para esta analogia.

Para sistema contínuos, o tempo de residência hidráulica (TRH) e a carga orgânica volumétrica (COV) são calculados da seguinte forma

$$
\begin{gathered}
\mathrm{TRH}=\frac{\mathrm{V}}{\mathrm{Q}} \\
\mathrm{COV}=\frac{\mathrm{QC}_{\mathrm{AT}}}{\mathrm{V}}
\end{gathered}
$$

Nas expressões (3.1) e (3.2), V é o volume do reator (L), Q a vazão de entrada e saída do fluido $(\mathrm{L} / \mathrm{h})$ e $\mathrm{C}_{\mathrm{AT}}$ é a concentração de matéria orgânica no afluente (mgDQO/L).

CAMARGO (2000) propôs modificações no cálculo desses parâmetros considerando-se as adaptações pertinentes para os reatores operados de modo intermitente: Assim sendo, o TRH e a COV são calculados da seguinte forma:

$$
\begin{gathered}
\mathrm{TRH}=\frac{\mathrm{t}_{\mathrm{C}} \mathrm{V}}{\mathrm{V}_{\mathrm{Ali}}} \\
\mathrm{COV}=\frac{\mathrm{V}_{\mathrm{Ali}} \mathrm{C}_{\mathrm{AT}}}{\mathrm{t}_{\mathrm{C}} \mathrm{V}}
\end{gathered}
$$


Nas equações (3.3) e (3.4), $\mathrm{V}_{\mathrm{Ali}}$ é o volume de água residuária alimentado por ciclo (L), $\mathrm{t}_{\mathrm{C}}$ é o tempo de duração do ciclo (h), V é o volume de meio no reator (L), e $\mathrm{C}_{\mathrm{AT}}$ é a concentração do substrato no afluente (mgDQO/L).

Dessa forma o TRH fornece uma idéia de quanto tempo é necessário para que haja o processamento de um volume de meio contido no reator, enquanto o COV permite identificar qual a carga orgânica aplicada, por unidade de volume e tempo no reator. Vale ressaltar que esses parâmetros complementam as informações de projeto para reatores em batelada.

\subsubsection{Imobilização da biomassa}

A associação de comunidades de microrganismos e superfícies, também chamadas de suporte, tem sido investigada desde que os primeiros instrumentos ópticos com capacidade de se visualizar o microcosmo foram criados. Desde Leewenhoek em meados de 1650, descrevendo o pequeno animaculates, cientistas têm observado diversos organismos de vida livre ou associado a superfícies (WIMPENNY et al. ${ }^{2}$ apud RIBEIRO, 2001). A presença de microrganismos aderidos a folhas e raízes vegetais, assim como a placa bacteriana dental, são exemplos da formação de biofilmes microbianos; este fenômeno tem importantes implicações em termos de erosão do solo, corrosão de metais e poluição das águas (VIJAYALAKSHIMI et al. $^{3}$ apud VALLERO, 1999).

${ }^{2}$ WIMPENNY, J.; MANZ, W.; SZEWZYK, U. (2000). Heterogeneity in biofilms. FEMS Microbiology, 24, pp.661-671. 
Segundo COSTERTON et al. (1995) biofilme é definido como uma população de bactérias aderidas umas às outras ou a uma superfície ou interface. Desse modo, incluem-se nessa definição agregados ou flocos microbianos e populações aderidas a meios suportes. A maioria dos biofilmes microbianos é, segundo COSTERTON \& LEWANDWSKI ${ }^{4}$ apud RIBEIRO (2001), composta de microcolônias de células envoltas por uma densa matriz de polímeros extracelulares, entremeadas por canais abertos. A formação desses canais está diretamente relacionada com as ações das forças cisalhantes do fluido, ao qual o biofilme está exposto.

A importância dos aglomerados de organismos é cada vez mais reconhecida, à medida que os pesquisadores dos tratamentos biológicos evoluem em seus conhecimentos sobre a participação dessas formações na degradação dos mais diversos substratos (CAMPOS, 1994).

Os biofilmes otimizam as operações e processos envolvidos no tratamento de águas residuárias, e sua maior vantagem, segundo VALLERO (1999), é que, diferentemente das culturas em suspensão, não há necessidade de incorporar medidas especiais para reter a biomassa no meio. Sabe-se também que reatores anaeróbios com microrganismos imobilizados (entende-se por imobilização qualquer técnica que

${ }^{3}$ ViJAYAlaKShiMi, M.A.; COCHET, N.; LEBEAUlt, J.M. (1990). Physicochemical aspects of cell adsorption. In: Wastewater treatment by immobilized cells. TYAGI, R.D.; VEMBU, K. (eds.) Ed. CRC Press, Boca Raton, cap.3, pp.45-79.

${ }^{4}$ COSTERTON, J.W.; LEWANDOWSKI, Z. (1997). The biofilm lifestyle. Advanced Dental Research, 11(1), pp.192-195. 
limite o livre movimento das células) apresentam melhores respostas quando submetidos a cargas de choque ou substâncias tóxicas, ocorrendo, em muitos casos, recuperação total do sistema (CABRAL, 2000).

Em contrapartida, em alguns casos são registrados problemas como a aceleração da corrosão e a formação gelatinosa verificada nas canalizações, conseqüência da ação de microrganismos. Registra-se também uma relação de compostos potencialmente tóxicos, em determinadas concentrações, a biofilmes, como amônia, clorofórmio, cianetos, formaldeídos, metais pesados e fenóis (HENZE \& HARREMÖES, 1983).

A viabilidade da aplicação dos sistemas anaeróbios operados em batelada tem sido estudada pelos grupos de pesquisa da EESC-USP e EEM-IMT por duas linhas de pesquisa em reatores anaeróbios operados em batelada e batelada alimentada. A primeira estuda a otimização dos parâmetros de operação usando microrganismos auto-imobilizados, e a segunda, o desenvolvimento de reatores anaeróbios operados em batelada contendo um suporte inerte para a imobilização da biomassa.

A agregação, fenômeno amplamente utilizado na digestão anaeróbia, vem sendo extensivamente estudada, devido principalmente à disseminação do sistema UASB (GUIOT et al., 1992; COSTERTON et al., 1995; BISHOP, 1997; LIU et al., 2002). Particularmente em reatores anaeróbios operados em batelada, WIRTZ \& DAGUE $(1996,1997)$ estudaram a granulação com o objetivo de diminuir o tempo de partida do sistema, e BANIK et al. (1997) pesquisaram a estrutura e a atividade metanogênica dos grânulos em um reator tratando água residuária diluída em baixas temperaturas. 
No que diz respeito à utilização de biomassa imobilizada, poucos são os trabalhos com reatores anaeróbios operados em batelada. Em contrapartida, registrase um grande número de sistemas de tratamento, principalmente filtros anaeróbios, usando o mecanismo de imobilização da biomassa através de suportes físicos. Mesmo que os suportes inorgânicos tenham um menor número de grupos reativos em relação ao material orgânico, estes têm sido usados com maior frequiência para a aderência microbiana. CAMPOS (1994) relata o uso de materiais como areia, brita, bambu, silicatos minerais, óxidos metálicos e material cerâmico para a formação de biofilmes. VERRIER et al. (1987) investigaram em seu trabalho a aderência de quatro culturas metanogênicas a superfícies de polímeros com diferente hidrofobicidade (porcelana, politetrafluoretileno, polipropileno e cloro polivinil), concluindo que a adesão das arqueas metanogênicas depende das características do meio suporte e da hidrofobicidade dos microrganismos.

VALLERO (1999) analisou a atividade biológica de células livres e imobilizadas, formadas em um reator anaeróbio. Para tal foi desenvolvido um reator cuja concepção permitia a retirada de lodo suspenso e de biofilmes íntegros, formados em quatro suportes inertes diferentes: espuma de poliuretano, cloro polivinil (PVC), tijolo refratário e cerâmica especial. Concluiu-se que tanto a porosidade quanto a espessura do biofilme (e as limitações de difusão correspondentes) influenciaram na velocidade global de consumo de substrato; contudo, não foi constatada nenhuma diferença entre o lodo suspenso e os biofilmes nas observações microscópicas.

ORTEGA et al. (2001) estudaram a aplicação de espumas cerâmicas produzidas via gelcasting em um biorreator anaeróbio, relacionando a composição 
microbiológica do biofilme com o tipo de material suporte. Para isso, materiais como argila expandida e borracha de etileno-propileno (EPR) foram submetidos a ciclos similares e comparados com os materiais cerâmicos. A quantidade de sólidos voláteis imobilizados foi maior nos suportes mais porosos e com maior tamanho de poros e os suportes cerâmicos (cerâmica de alumina e de caulim) apresentaram as maiores capacidades de retenção celular, sugerindo que tais materiais apresentam condições ótimas para a adesão e desenvolvimento de biofilme anaeróbio.

HUYSMAN et al. (1983) utilizaram espuma de poliuretano como suporte inerte em um reator metanogênico de fluxo ascendente. Neste estudo, observou-se a influência do tamanho dos cubos de espuma, uma vez que na utilização de um único pedaço do material, houve rápida acidificação no reator. Os autores sugerem que a aderência dos microrganismos metanogênicos em espuma de poliuretano é comparativamente, mais mecânica do que eletrostática, opinião compartilhada por FYNN \& WHITMORE (1984), que reportaram a alta capacidade de retenção de organismos através da imobilização com partículas de espuma de poliuretano. GIJZEN et al. (1988) concluíram, após estudos no tratamento de água residuária proveniente da manufatura de papel, que a espuma de poliuretano pode ser utilizada como um ótimo material de suporte para o crescimento do consórcio microbiano em sistemas anaeróbios.

ZAIAT et al. (1994) apresentaram uma nova configuração de reator anaeróbio com fluxo horizontal e leito fixo, empregando espuma de poliuretano como suporte da biomassa. Posteriormente, VARESCHE et al. (1997) caracterizaram a biomassa anaeróbia presente em um reator do mesmo tipo e observaram diferentes tipos de imobilização da microflora nas matrizes de espuma: retenção de micro- 
grânulos (270-470 $\mu \mathrm{m}$ de diâmetro) no meio poroso da espuma, adesão de microcolônias na superfície e células individuais aderidas ao suporte.

RATUSZNEI et al. (2000) propuseram uma nova configuração para um reator anaeróbio agitado operado em batelada, também utilizando a imobilização da biomassa em partículas cúbicas de espuma de poliuretano. O uso deste suporte propiciou a melhora na retenção de sólidos, além de eliminar a fase de sedimentação, levando a um menor tempo de ciclo. A partir desses estudos, a influência da agitação em um sistema com biomassa imobilizada tratando água residuária sintética, foi investigada. Com valores de agitação variando entre 0 e $750 \mathrm{rpm}$ os pesquisadores obtiveram eficiências de remoção de 90 e $92 \%$ para valores de 350 e 500 rpm respectivamente (RATUSZNEI et al., 2001).

CAMARGO et al. (2002), tratando água residuária sintética a base de glicose (500 mgDQO/L) obtiveram um incremento no desempenho de um ASBR com biomassa imobilizada através da implantação de recirculação da fase aquosa. A eficiência de remoção de matéria orgânica não filtrada (em termos de DQO) aumentou de $83 \%$ para $95 \%$ como conseqüência do melhor contato substrato/ biomassa.

\subsubsection{Estratégia de alimentação}

Segundo ZAIAT et al. (2001), os fatores que geralmente afetam o rendimento de um ASBR são a agitação, a razão entre a concentração de substrato e a concentração de biomassa (F/M), a configuração geométrica do reator e a estratégia 
de alimentação. Embora os três primeiros aspectos já tenham sido estudados, trabalhos sobre a estratégia de alimentação são ainda escassos na literatura.

O ASBR não necessita de sistemas de alimentação complexos devido à sua configuração, que dispõe a biomassa uniformemente no reator. $\mathrm{O}$ processo de batelada é caracterizado pela alimentação em um período curto em relação ao tempo de ciclo, que proporciona uma boa homogeneização entre o substrato e a biomassa. Dessa maneira, as mais altas concentrações de substrato são atingidas logo após o término da alimentação.

Em situações onde haja o interesse em manter a concentração do substrato baixa, pode ser empregada a estratégia de alimentação conhecida como batelada alimentada, em que o enchimento ocorre durante a etapa de reação. Este tipo de estratégia pode ser usado em caso de presença de substâncias tóxicas ou inibidoras na água residuária, elevadas cargas orgânicas, ou ainda em situações de restrições operacionais.

A estratégia de alimentação em reatores operados em batelada ou batelada alimentada tem fundamental importância para o desempenho do ASBR, uma vez que o tempo gasto na etapa de enchimento está diretamente ligado ao valor de F/M (ZAIAT et al., 2001). Ademais, o tempo de alimentação é um parâmetro operacional e de projeto, uma vez que define o número de reatores a serem utilizados na operação.

De acordo com ANGENENT \& DAGUE (1995), o aumento no tempo de alimentação resulta em decréscimo na concentração total de ácidos voláteis, que são produtos intermediários na degradação anaeróbia. A utilização de uma fase de enchimento longa limita o fornecimento de substrato primário evitando a 
acidificação do reator. Resultados obtidos por BAGLEY \& BRODKORB (1999) confirmam estas proposições, principalmente para águas residuárias simples de rápida degradação. Os autores sugerem, no entanto, a realização de experimentos para a validação dessa hipótese no uso de substratos complexos. Observa-se que nesses casos o reator deve ser analisado como um reator anaeróbio operado em batelada alimentada seqüencial.

KENNEDY et al. (1991) investigaram o efeito da razão tempo de alimentação/tempo de ciclo no desempenho de um reator operado em batelada. O substrato sintético utilizado, feito à base de sacarose, possuía concentração de matéria orgânica média de $7000 \mathrm{mgDQO} / \mathrm{L}$. Os autores indicam a influência da razão $t_{\mathrm{F}} / \mathrm{t}_{\mathrm{C}}$ no projeto do reator, principalmente quando elevados valores de carga orgânica volumétrica (acima de 9000 mgDQO/L.d) são implementados. Nessas condições, registrou-se quedas acima de 25\% nos valores médios de eficiência de remoção, quando baixos índices $t_{\mathrm{F}} / \mathrm{t}_{\mathrm{C}}$ foram implementados. Todavia, em valores menores que 9000 mg/L.d o processo não foi afetado pela estratégia de alimentação.

SUTHAKER et al. (1991), após estudarem o sistema ASBR em diferentes condições operacionais (substrato à base de glicose com concentração de $35000 \mathrm{mgDQO} / \mathrm{L}$; temperatura variando entre 25 e $34{ }^{\circ} \mathrm{C}$; razões $\mathrm{t}_{\mathrm{F}} / \mathrm{t}_{\mathrm{C}}$ entre 0 e 0,75$)$, obtiveram melhores resultados (remoção máxima de $73 \%$ para amostras filtradas) para ciclos de 16 dias, com tempo de alimentação de 4 dias e concluíram que nas condições estudadas, o tempo de alimentação (valores absolutos) exerce maior influência do que a razão $t_{\mathrm{F}} / \mathrm{t}_{\mathrm{C}}$, sendo, portanto, fator preponderante na estratégia de alimentação. 
DROSTE \& MASSÉ (1995) e MASSÉ et al. (1996) não observaram variações no rendimento do ASBR quando as condições de alimentação foram mudadas. SHIZAS \& BAGLEY (2002), trabalhando com um ASBR tratando água residuária à base de glicose (3,2 gDQO/L.d), estudaram a variação do desempenho do reator com a modificação de alguns parâmetros operacionais (concentração de substrato afluente, tempo do ciclo e razão $t_{\mathrm{F}} / \mathrm{t}_{\mathrm{C}}$ ). Os autores concluíram que a adoção de tempos de alimentação maiores causa impacto positivo no rendimento do sistema, uma vez que no tratamento de águas residuárias de fácil degradação a produção de ácidos voláteis cai rapidamente com o aumento da razão $t_{F} / t_{C}$.

RODRIGUES et al. (2003) concluíram que a utilização de tempos de alimentação longos (razões t $/ t_{\mathrm{C}}$ maiores que 0,5) não influenciou o desempenho do sistema, que era constituído por um ASBR contendo biomassa granulada agitado mecanicamente $(50 \mathrm{rpm})$ tratando água residuária sintética (aproximadamente $500 \mathrm{mgDQO} / \mathrm{L})$. Foram obtidas constantes cinéticas aparentes com o ajuste de um modelo de primeira ordem nos experimentos realizados (batelada, batelada alimentada seguida de batelada e batelada alimentada).

RATUSZNEI et al. (2003) notaram que a eficiência do ASBR proposto anteriormente (RATUSZNEI et al., 2000), caiu drasticamente quando um longo período de alimentação foi aplicado; ademais, os autores citam que a eficiência obtida no final do ciclo não foi mantida na operação em batelada alimentada. Nesse trabalho, o reator foi todo preenchido com o leito contendo microrganismos imobilizados em espuma de poliuretano, com o intuito de aumentar a quantidade de biomassa no sistema; conseqüientemente, o reator era progressivamente inundado com a água residuária em função do tempo de alimentação, atingindo a condição de 
totalmente afogado apenas no final desse período. Portanto, a biomassa entrava em contato com a água residuária na medida que o leito era inundado, o que pode ter causado os problemas registrados.

\subsection{Considerações finais}

Os trabalhos apresentados na literatura reiteram a importância do desenvolvimento dos sistemas de alto desempenho, com destaque as novas propostas surgidas na última década.

Com a continuidade das pesquisas em tratamento ana eróbio, as vantagens inerentes à adoção desses novos reatores serão amplamente reconhecidas; conseqüentemente, a implementação dessas configurações para o tratamento de diversos tipos de águas residuárias se tornará realidade.

Entretanto, a disseminação do uso do reator anaeróbio operado em batelada seqüencial em escala plena ainda está distante. Trabalhos específicos sobre a utilização dessa tecnologia não têm sido encontrados na literatura e os problemas mais freqüentemente encontrados continuam sendo estudados.

As altas eficiências obtidas nos trabalhos consultados vislumbram o estabelecimento do uso de sistemas em batelada, desde que os aspectos ainda não elucidados sejam bem entendidos. A avaliação do ASBR quando submetido a diferentes estratégias de alimentação, foco do presente trabalho, é, portanto, tema relevante, e nesse sentido estudos aprofundados contribuirão para a avaliação da real aplicabilidade dos reatores anaeróbios operados em batelada seqüencial. 


\section{CAPÍTULO 4}

\section{MATERIAIS E MÉTODOS}

\subsection{Materiais}

\subsubsection{Configuração do Reator}

O sistema proposto nesse trabalho é baseado no reator apresentado por RATUSZNEI et al. (2000); no entanto a agitação foi feita mecanicamente, enquanto no trabalho citado era utilizada agitação magnética. Trata-se de um reator confeccionado em acrílico, com formato cilíndrico de $200 \mathrm{~mm}$ de diâmetro e $200 \mathrm{~mm}$ de altura, com capacidade total 6,3 litros. Com base nos estudos de CUBAS et al. (2002) e RATUSZNEI et al. (2001), optou-se por uma agitação de 500 rpm, implementada por um agitador mecânico com inversor de freqüência (Marconi ${ }^{\circledR}$ modelo MA 259), com um impelidor tipo turbina (diâmetro de $60 \mathrm{~mm}$ ) constituído de seis pás planas. Bombas tipo diafragma (ProMinent ${ }^{\circledR}$, modelos $\beta 4, \beta 5$ e Concept B) realizaram a alimentação e a descarga do sistema, auxiliadas por um sistema de automação composto por temporizadores (Grasslin ${ }^{\circledR}$, modelo Logica 500). O sistema experimental foi instalado em uma câmara mantida em $30 \pm 1{ }^{\circ} \mathrm{C}$; devido a um sistema de aquecimento composto por resistências e ventiladores, além de um sensor e 
controlador de temperatura (Novus ${ }^{\circledR}$, modelo N480). A Figura 4.1 mostra uma representação esquemática do reator proposto e fotografias da montagem experimental são apresentadas nas Figura 4.2. e 4.3. Aspectos construtivos do sistema são detalhados no Apêndice I.

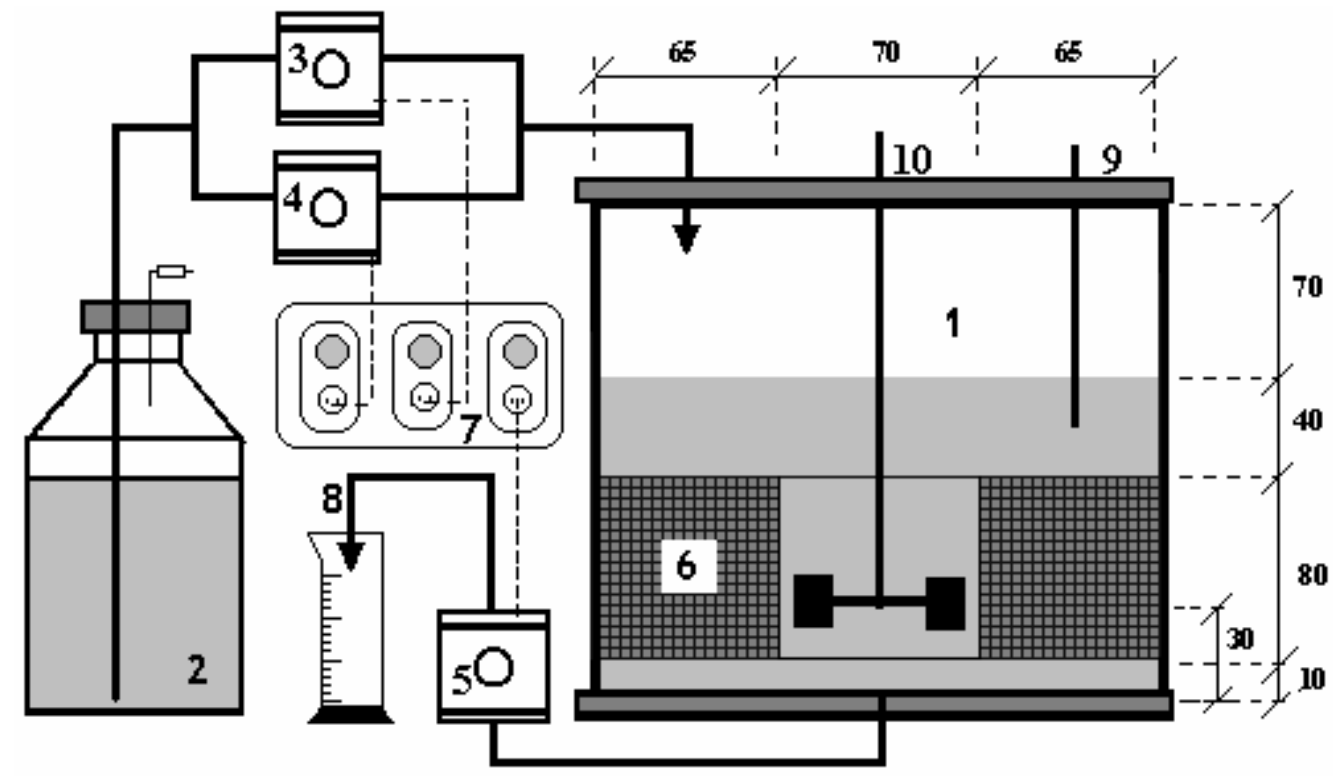

FIGURA 4.1: Esquema do reator anaeróbio operado em batelada seqüencial contendo biomassa imobilizada [Notação (figura sem escala e cotas em milímetros): (1) Tanque de reação, (2) Substrato esterilizado, (3) Bomba de alimentação tipo diafragma, (4) Bomba de alimentação tipo diafragma (5) Bomba de descarga tipo diafragma (6) Cesto de aço inoxidável contendo partículas de espuma com células imobilizadas, (7) Temporizadores, (8) Efluente tratado, (9) Termômetro, (10) Agitador mecânico)]. 


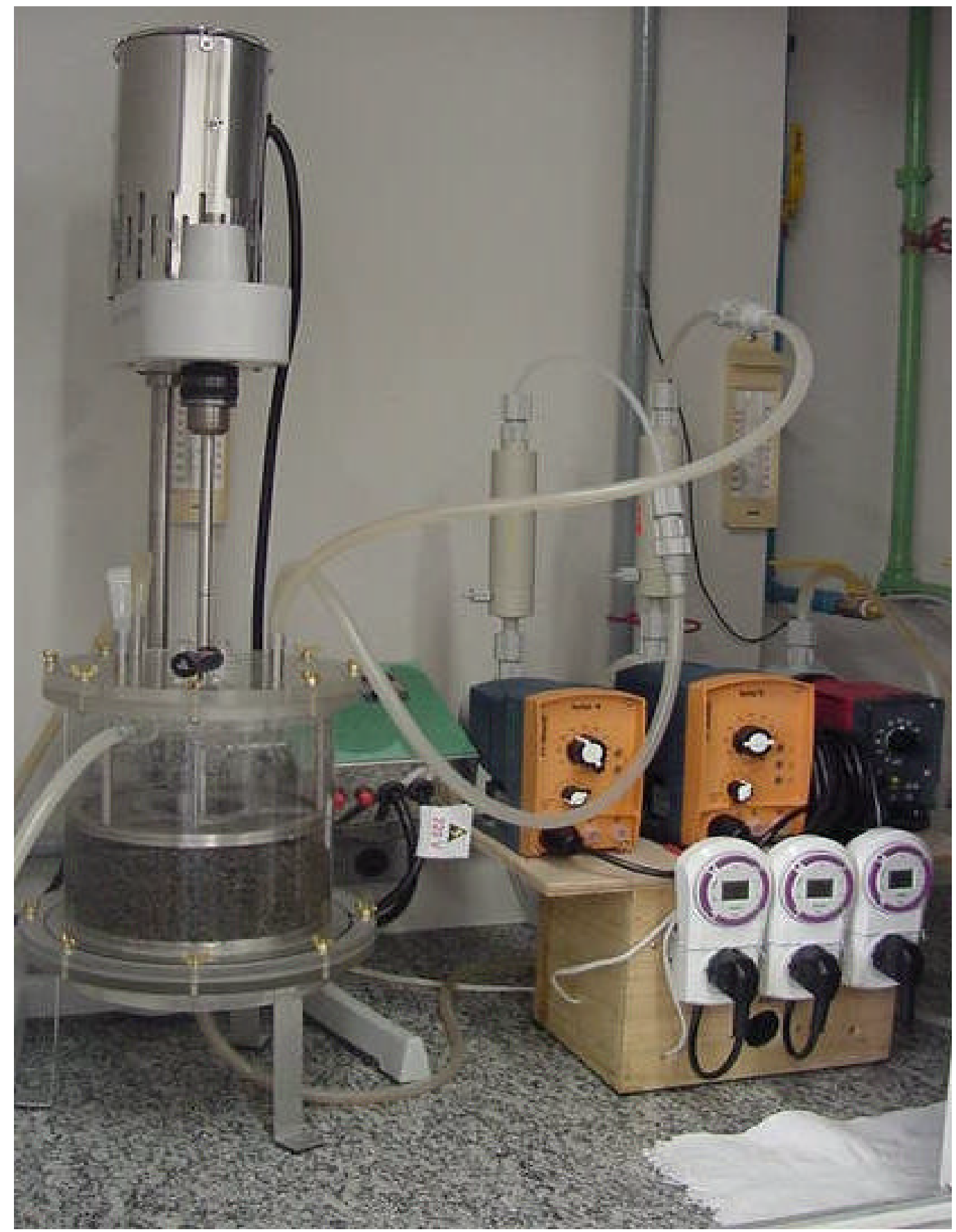

FIGURA 4.2: Fotografia da montagem experimental. 


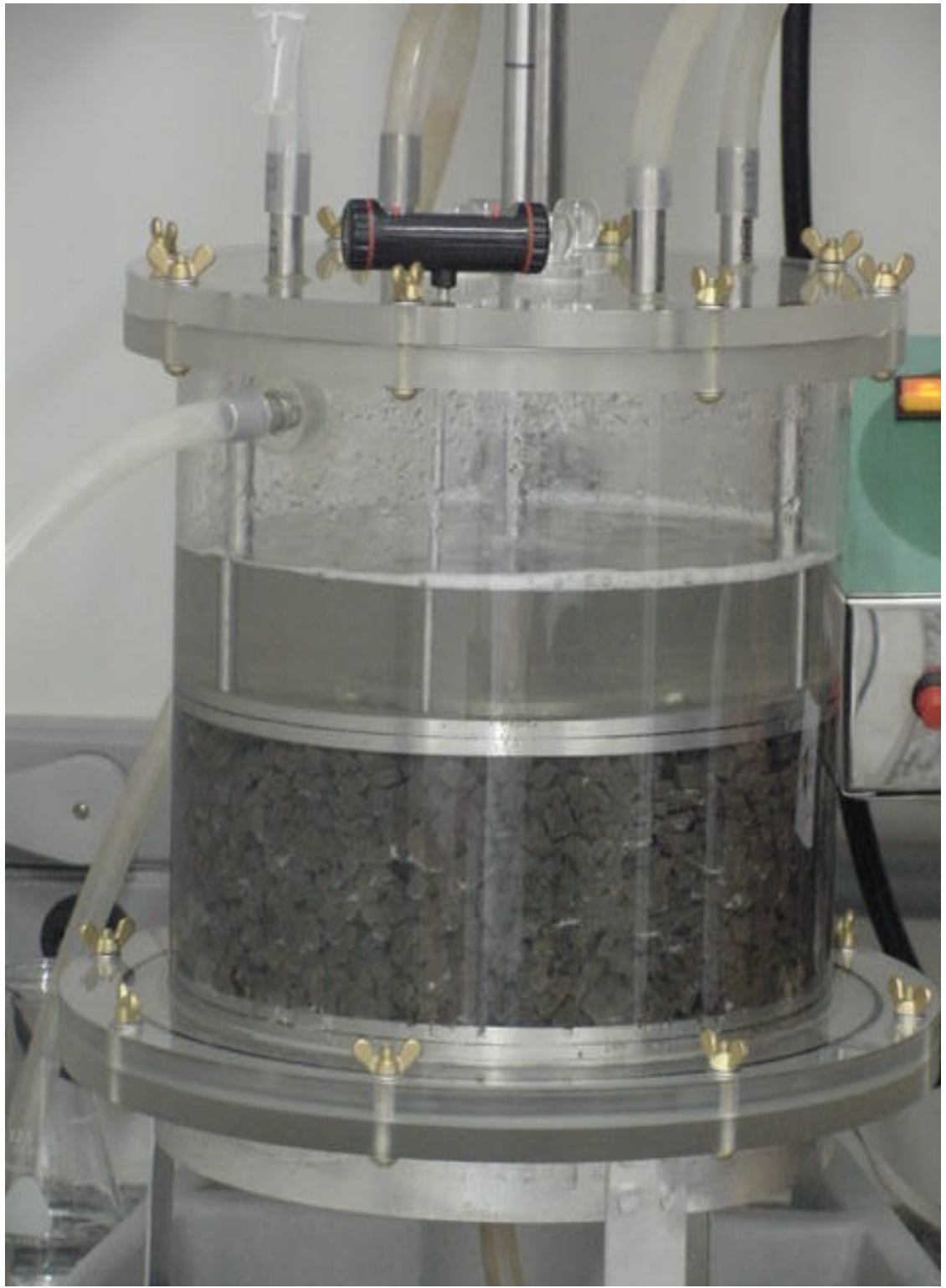

FIGURA 4.3: Detalhe do reator confeccionado em acrílico com o cesto contendo espuma de poliuretano com biomassa imobilizada.

O material suporte com as células imobilizadas foi confinado em um cesto de aço inoxidável 310 (80 $\mathrm{mm}$ de altura), com um cilindro no meio (diâmetro de $70 \mathrm{~mm}$ ), onde foi introduzido o eixo de agitação (Figura 4.4). 


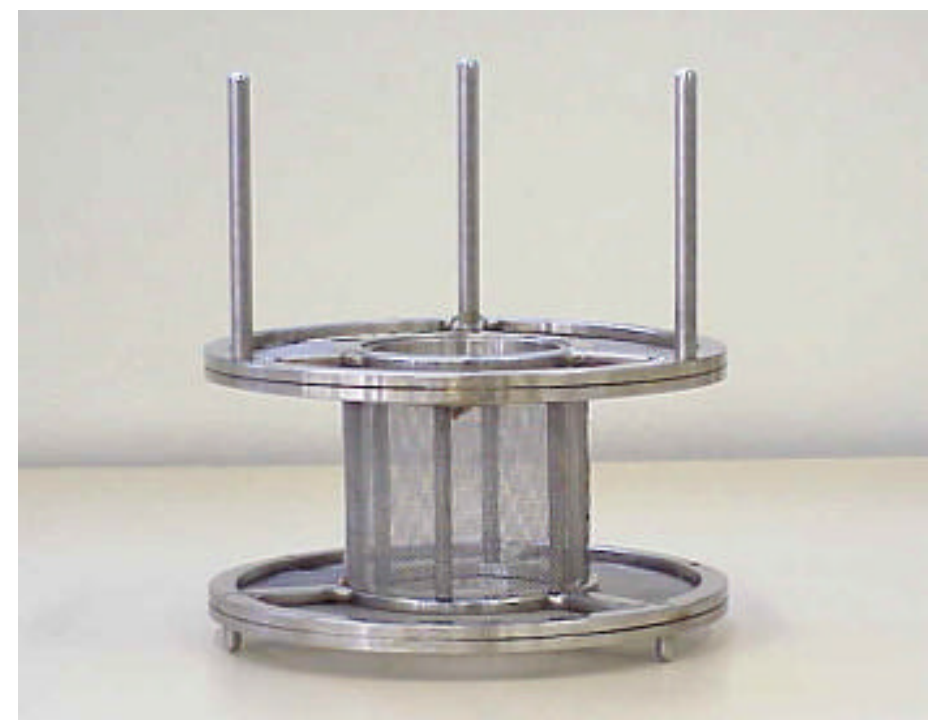

FIGURA 4.4: Fotografia do cesto de aço inoxidável, onde foi alocada a espuma de poliuretano com a biomassa imobilizada.

\subsubsection{Material suporte para a imobilização da biomassa}

Como suporte de imobilização das biopartículas, foi usada espuma de poliuretano na forma de cubos com $10 \mathrm{~mm}$ de aresta, produzida pela empresa Edmil Indústria e Comércio de Elói Mendes-MG. O material, fabricado sem aditivos ou corantes, possui porosidade próxima a $95 \%$ e densidade aparente de $23 \mathrm{~g} / \mathrm{L}$

\subsubsection{Inóculo}

O inóculo utilizado em todos os experimentos (concentração de sólidos suspensos voláteis de $38 \mathrm{mgSSV} / \mathrm{L}$ ) era proveniente de um reator anaeróbio de fluxo 
ascendente e manta de lodo (UASB) que operava com bons resultados, tratando água residuária de um abatedouro de aves (Dacar Industrial S/A, Tietê-SP).

\subsection{4. Água residuária}

O biorreator foi alimentado com 2,5 1tros de um substrato sintético com demanda química de oxigênio de aproximadamente $500 \mathrm{mgDQO} / \mathrm{L}$, composto por proteínas (na forma de extrato de carne), carboidratos de fácil e de difícil degradação (nas formas de sacarose, amido e celulose) e lipídeos (na frma de óleo de soja), contendo também bicarbonato de sódio para a neutralização do sistema e micronutrientes ( $\mathrm{Mg}, \mathrm{Na}$ e $\mathrm{Ca})$. O substrato foi preparado de acordo com TORRES (1992) esterilizado a $121^{\circ} \mathrm{C}$ por 15 minutos. É importante citar que essa composição de substrato sintético foi utilizada em vários experimentos realizados na EESC/USP e na EEM/IMT, reproduzindo as características de esgotos domésticos. A composição da água residuária sintética é apresentada nas Tabelas 4.1 e 4.2.

TABELA 4.1: Composição percentual da matéria orgânica no substrato.

Fonte: TORRES (1992).

\begin{tabular}{ccc}
\hline Composto orgânico & DQO $(\%)$ & Constituinte \\
\hline Proteínas & 50 & Extrato de carne \\
Carboidratos & 40 & Sacarose, amido, celulose \\
Lipídeos & 10 & Óleo de soja \\
\hline
\end{tabular}


TABELA 4.2: Composição da água residuária sintética utilizada nos experimentos.

Fonte: TORRES (1992).

\begin{tabular}{ll}
\hline Composto & Concentração $(\mathrm{mg} / \mathrm{L})$ \\
\hline
\end{tabular}

\section{Carboidratos}

Sacarose

Amido

Celulose

\section{Proteínas}

Extrato de carne

\section{Lipídeos}

Óleo de soja*

Sais

$\mathrm{NaCl}$

$\mathrm{MgCh} .6 \mathrm{H}_{2} \mathrm{O}$

$\mathrm{CaCl}_{2} \cdot 2 \mathrm{H}_{2} \mathrm{O}$

Tampão

$\mathrm{NaHCO} 3$ 


\subsection{Fundamentos teóricos}

\subsubsection{Eficiência de remoção de matéria orgânica}

A eficiência da remoção total da matéria orgânica no sistema foi definida pela Equação (4.1):

$$
\varepsilon_{\mathrm{ST}}(\%)=\frac{\mathrm{C}_{\mathrm{AT}}-\mathrm{C}_{\mathrm{ST}}}{\mathrm{C}_{\mathrm{AT}}} 100
$$

Em que $\mathrm{C}_{\mathrm{AT}}$ é a concentração total de substrato no afluente e $\mathrm{C}_{\mathrm{ST}}$ é a concentração total de substrato no efluente.

A eficiência de remoção para amostras filtradas é dada por $\varepsilon_{\mathrm{SF}}$, definida pela Equação (4.2):

$$
\varepsilon_{\mathrm{SF}}(\%)=\frac{\mathrm{C}_{\mathrm{AT}}-\mathrm{C}_{\mathrm{SF}}}{\mathrm{C}_{\mathrm{AT}}} 100
$$

Em que $\mathrm{C}_{\mathrm{AT}}$ é a concentração total de substrato no afluente e $\mathrm{C}_{\mathrm{SF}}$ é a concentração de substrato filtrada no efluente.

É interessante ressaltar que na obtenção de perfis dinâmicos de matéria orgânica, a eficiência de remoção é calculada em relação à concentração de matéria orgânica filttrada no reator no início do ciclo $\left(\mathrm{C}_{\mathrm{SF} 0}\right)$, que é menor que a concentração do afluente devido ao efeito de diluição. Dessa maneira, para os perfis obtidos, os valores de eficiência são dados pela Equação (4.3): 


$$
\varepsilon(\%)=\frac{\mathrm{C}_{\mathrm{SF} 0}-\mathrm{C}_{\mathrm{SF}}}{\mathrm{C}_{\mathrm{SF} 0}} 100
$$

\subsubsection{Ajuste do modelo cinético aos dados experimentais}

Um modelo cinético de primeira ordem foi ajustado aos dados dos perfis de conversão de substrato ao longo do ciclo obtidos para as várias estratégias de alimentação pesquisadas, de maneira análoga ao descrito por RODRIGUES et al. (2003). Inicialmente, fez-se o balanço material para o reator perfeitamente agitado e isotérmico, admitindo-se a ocorrência de uma reação biológica (Equações 4.4 e 4.5):

$$
\begin{gathered}
\frac{d V}{d t}=Q \\
\frac{d_{S}}{d t}=D\left(C_{A F}-C_{s}\right)-R_{s}
\end{gathered}
$$

Sendo válida a seguinte nomenclatura:

$\mathrm{C}_{\mathrm{S}}$ Concentração de substrato para amostras filtradas no reator (mgDQO/L).

$\mathrm{C}_{\mathrm{AF}}$ Concentração de substrato filtrado na alimentação (mgDQO/L).

D Velocidade específica de alimentação $\left(\mathrm{h}^{-1}\right)$.

Q Vazão (constante) de alimentação (L/h).

$\mathrm{R}_{\mathrm{S}}$ Velocidade de consumo de substrato (mgDQO/L.h).

t Tempo decorrido de ensaio (h).

V Volume de meio no reator (L). 
O modelo cinético utilizado (Equação 4.6) foi deduzido a partir do modelo proposto por Monod, admitindo-se que a concentração de biomassa permaneça constante (hipótese bastante aceita para o metabolismo anaeróbio em experimentos de curta duração).

$$
\mathrm{R}_{\mathrm{S}}=\mathrm{r}_{\mathrm{S}} \mathrm{C}_{\mathrm{X}}=\frac{\mu}{\mathrm{Y}_{\mathrm{X} / \mathrm{S}}}\left(\frac{\mathrm{X}}{\mathrm{V}}\right)=\frac{1}{\mathrm{Y}_{\mathrm{X} / \mathrm{S}}} \frac{\mu_{M a x} C_{S}}{K_{S}+C_{S}}\left(\frac{X}{V}\right)
$$

Sabe-se que os valores de concentração de substrato são de aproximadamente $500 \mathrm{mgDQO} / \mathrm{L}$, considerados reduzidos. Nestas condições, pode-se simplificar o modelo proposto por Monod por um modelo de primeira ordem (Equação 4.7).

$$
\mathrm{r}_{\mathrm{S}} \mathrm{C}_{\mathrm{X}}=\mathrm{k}_{1}\left(\frac{\mathrm{X}}{\mathrm{V}}\right) \mathrm{C}_{\mathrm{S}}
$$

Considerando a existência de um valor residual de substrato, no qual a velocidade de consumo deste é praticamente nula, modificourse o modelo cinético de forma a incluir essa concentração residual (Equação 4.8).

$$
\mathrm{r}_{\mathrm{S}} \mathrm{C}_{\mathrm{X}}=\mathrm{k}_{1}\left(\frac{\mathrm{X}}{\mathrm{V}}\right)\left(\mathrm{C}_{\mathrm{S}}-\mathrm{C}_{\mathrm{SR}}\right)
$$

Sendo válida a nomenclatura:

$\mathrm{C}_{\mathrm{SR}}$ Concentração de substrato residual a partir da qual a velocidade de consumo de substrato é zero (mgDQO/L). 
$\mathrm{C}_{\mathrm{X}}$ Concentração de biomassa (mgSVT/L).

Q Vazão (constante) de alimentação (L/h).

$\mathrm{k}_{1}$ Parâmetro cinético aparente do modelo $\left(=\mu_{\mathrm{Max}} / \mathrm{Y}_{\mathrm{X} / \mathrm{S}} \quad \mathrm{k}_{\mathrm{S}}\right)$ (1/(h.mgSVT/L)).

$\mathrm{K}_{\mathrm{S}}$ Constante cinética do modelo proposto por Monod (mgDQO/L).

$\mathrm{R}_{\mathrm{S}} \quad$ Velocidade de consumo de substrato, (mgDQO/L.h).

$\mathrm{r}_{\mathrm{S}} \quad$ Velocidade específica de consumo de substrato (mgDQO/mgSVT.h).

X Quantidade de biomassa no reator (gSVT).

$\mathrm{Y}_{\mathrm{X} / \mathrm{S}}$ Fator de conversão entre biomassa formada e substrato consumido (mgSVT/mgDQO).

$\mu$ Velocidade específica de crescimento de biomassa (mgSVT/ mgSVT. h).

$\mu_{\text {Max }}$ Velocidade específica máxima de crescimento de biomassa (mgSVT/ mgSVT. h).

O modelo proposto foi formulado admitindo-se cinética de reação homogênea, ou seja, o parâmetro cinético $\mathrm{k}_{1}$ é uma constante classificada como aparente, pois inclui em sua síntese as resistências à transferência de massa interna e externa aos grânulos além do fenômeno de reação bioquímica.

$\mathrm{O}$ ajuste do parâmetro cinético $\mathrm{k}_{\mathfrak{l}}$ foi realizado pelo ajuste não linear das equações (4.4), (4.5) e (4.8) aos dados experimentais através do procedimento numérico de Levenberg-Marquardt acoplado ao procedimento de resolução de sistema de equações diferenciais pelo método de Runge-Kutta-Gill com passo de integração variável (PRESS et al., 1986). Inicialmente ajustourse o modelo aos dados 
obtidos no ensaio em batelada (ou seja, $\mathrm{Q}=0$ ), obtendo-se $\mathrm{k}_{1}{ }^{\mathrm{B}}$. Esse parâmetro foi mantido constante para todas as fases de operação em batelada. Dessa forma, para o ajuste do modelo aos dados obtidos nos ensaios em batelada alimentada seguida de batelada, obteve-se o parâmetro $\mathrm{k}_{1}{ }^{\mathrm{BA}}$ para a fase em batelada alimentada, utilizandose o parâmetro $k_{1}{ }^{B}$ para a fase em batelada. Para o ajuste do modelo aos dados obtidos no ensaio em batelada alimentada, obteve-se o parâmetro $\mathrm{k}_{1}{ }^{\mathrm{BA}}$ sem a necessidade da utilização do parâmetro $\mathrm{k}_{1}{ }^{\mathrm{B}}$.

Os ajustes cinéticos foram realizados em dois procedimentos: (i) estimativa do parâmetro cinético aparente $\mathrm{k}_{1}$ pelo ajuste do modelo aos dados experimentais, mantendo-se os valores para concentração de substrato residual $\left(\mathrm{C}_{\mathrm{SR}}\right)$ iguais as médias obtidas através dos experimentos; e (ii) estimativa de ambos, parâmetro cinético aparente $\left(\mathrm{k}_{1}\right)$ e concentração de substrato residual $\left(\mathrm{C}_{\mathrm{SR}}\right)$ pelo ajuste do modelo aos dados experimentais.

\subsection{Métodos analíticos}

\subsubsection{Análises físico-químicas}

As variáveis operacionais concentrações de substrato (medida como demanda química de oxigênio-DQO) nas formas não filtrada e filtrada, de sólidos (totais, totais voláteis, suspensos totais e suspensos voláteis), de ácidos voláteis totais, de alcalinidade (total, parcial, intermediária e a bicarbonato) foram monitoradas segundo o Standard methods for examination of water and wastewater (APHA et al., 
1995), considerando também o método proposto por RIPLEY et al. (1986) na determinação da alcalinidade.

A composição do biogás gerado pela degradação anaeróbia foi analisada através de cromatografia gasosa, utilizando-se o cromatógrafo Hewlett Packard $^{\circledR}$ 6890 Series com detector de condutividade térmica.

\subsubsection{Análises microbiológicas}

As amostras de biopartículas de espuma de poliuretano foram retiradas do reator em duas oportunidades: durante o ensaio em batelada alimentada ( $2 \mathrm{~h})$ seguida de batelada (6 h) e após o término do ensaio em batelada alimentada (6 h) seguida de batelada (2 h). Os cubos de espuma contendo microrganismos imobilizados foram retirados de diferentes cotas ao longo da altura do reator e alocados em frascos de $20 \mathrm{~mL}$ em meio a nitrogênio gasoso, mantidos a $10{ }^{\circ} \mathrm{C} . \mathrm{O}$ material foi analisado no Laboratório de Processos Biológicos do Departamento de Hidráulica e Saneamento da EESC/USP. A análise microbiológica do lodo anaeróbio foi feita por microscopia ótica e contraste de fase utilizando-se um microscópio Olympus ${ }^{\circledR}$, modelo BH2. Através deste procedimento, a presença dos diversos grupos bacterianos característicos da biomassa anaeróbia foi avaliada. 


\subsection{Procedimento experimental}

\subsubsection{Imobilização da biomassa anaeróbia}

O lodo anaeróbio foi imobilizado em partículas cúbicas de espuma de poliuretano, conforme metodologia proposta por ZAIAT et al. (1994). O procedimento de fixação dos microrganismos é realizado da seguinte forma:

(a) O lodo granulado usado como inóculo é macerado, utilizando-se uma peneira com abertura de $1 \mathrm{~mm}$ e uma colher, no intuito de que a imobilização na espuma seja facilitada com a destruição dos grânulos.

(b) O inóculo peneirado é alocado em um béquer. Os cubos de espuma de poliuretano são adicionados e procede-se a mistura de tal forma que todo o material suporte esteja em contato com a suspensão.

(c) Decorridas 2 horas para uma melhor aderência do inóculo à espuma, as matrizes com as células aderidas são colocadas em meio (o mesmo utilizado no experimento) para lavagem dos sólidos fracamente fixados. O meio é drenado e dessa maneira os cubos de poliuretano com inóculo aderido são acondicionados no reator sem serem comprimidos. A compressão do material pode resultar no surgimento de zonas com fluxo interrompido, comprometendo a boa homogeneização do meio.

A Figura 4.5 ilustra uma comparação entre os cubos de espuma de poliuretano no estado natural e com a biomassa imobilizada. 


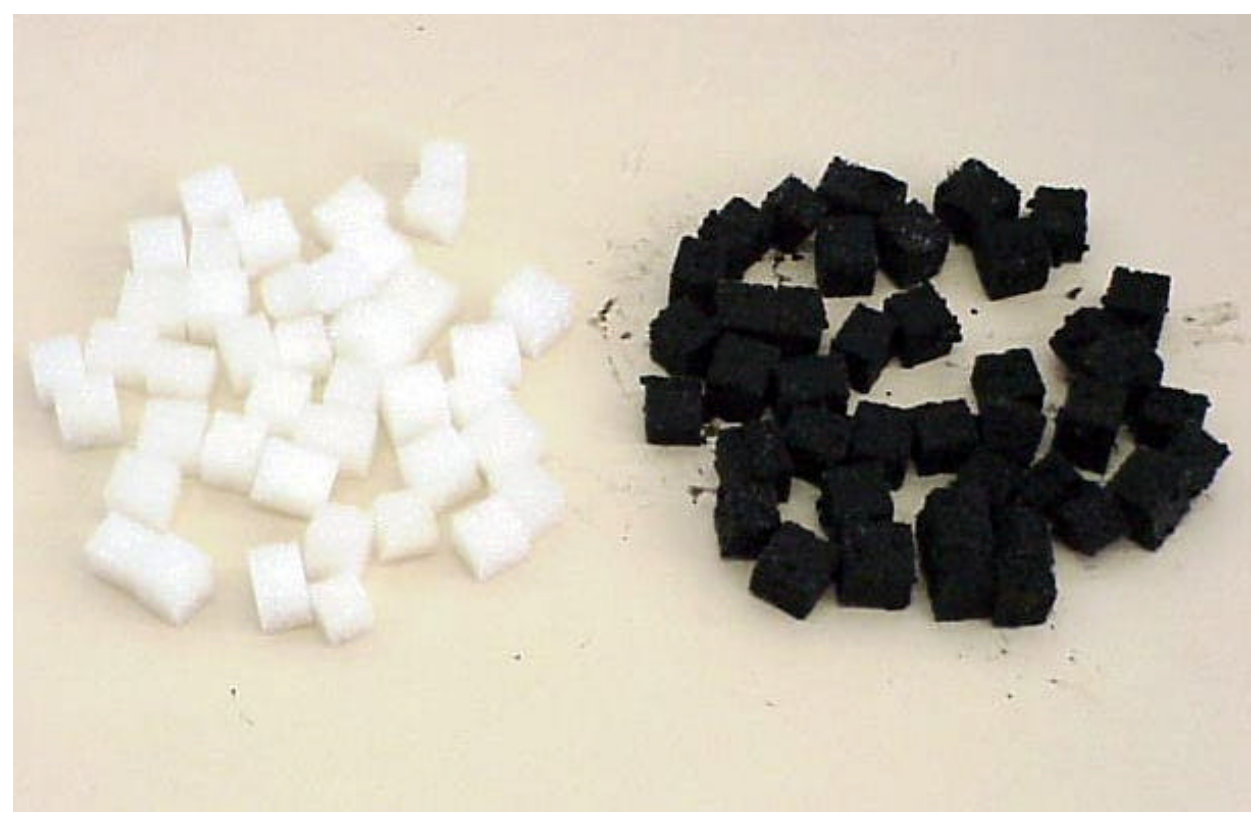

FIGURA 4.5: Cubos de espuma de espuma de poliuretano antes e após a imobilização da biomassa.

\subsubsection{Operação do reator}

O reator foi operado à temperatura de $30 \pm 1{ }^{\circ} \mathrm{C}$ com concentração de substrato afluente de aproximadamente $500 \mathrm{mgDQO} / \mathrm{L}$. O ciclo de operação em batelada do reator possuía 8 horas e uma agitação de 500 rpm foi implementada. Esses valores foram adotados com base em resultados obtidos nos sistemas em operação no Laboratório de Engenharia Bioquímica do Departamento de Engenharia Química e de Alimentos da EEM/IMT. No início de um ciclo de operação, o reator foi alimentado com um volume de 1,5 L de água residuária sintética durante um período de 10 minutos. Na seqüência, um volume adicional de 1,0 L de água residuária alimentava com vazão constante o reator durante um novo período. O tempo de alimentação adicional caracterizou as diferentes condições de alimentação. A 
estratégia de alimentação foi estabelecida pelo tempo de carga do reator nas seguintes condições:

(a) Operação em batelada, em que a alimentação de todo o volume $(2,5$ L) foi efetuada em 10 minutos.

(b) Período de alimentação adicional de 120 minutos, caracterizando a operação em batelada alimentada durante 1/4 do ciclo. Nessa condição, o reator foi alimentado com 1,5 L em 10 minutos e 1,0 L em 2 horas.

(c) Período de alimentação adicional de 240 minutos, caracterizando a operação em batelada alimentada durante 1/2 do ciclo. Nessa condição, o reator foi alimentado com 1,5 L em 10 minutos e 1,0 L em 4 horas.

(d) Período de alimentação adicional de 360 minutos, caracterizando a operação em batelada alimentada durante $3 / 4$ do ciclo. Nessa condição, o reator foi alimentado com 1,5 L em 10 minutos e 1,0 L em 6 horas.

(e) Período de alimentação de 470 minutos, caracterizando a operação em batelada alimentada durante toda a fase de reação. Nessa última condição proposta, o reator foi alimentado com $1,5 \mathrm{~L}$ em 10 minutos e $1,0 \mathrm{~L}$ durante o restante da fase de reação.

Ao término do ciclo, o efluente era descarregado durante 10 minutos e após o esvaziamento do reator, estabeleceu-se um intervalo de tempo de 1 minuto como segurança no sincronismo de operação das bombas usadas na alimentação e descarga, para que então, o próximo ciclo fosse reiniciado.

Ressalta-se que devido ao enfoque recebido em diversos trabalhos nos últimos anos, optou-se pela adoção da operação em batelada como base para a comparação das estratégias de alimentação implementadas. 
Os ensaios realizados duraram 30 dias (ensaio preliminar para a verificação do funcionamento do sistema e ajustes operacionais), 29 dias (operação do reator em batelada -8 h), 42 dias (operação do reator em batelada alimentada $-2 \mathrm{~h}$-, seguida de batelada -6 h), 36 dias (ensaio em batelada alimentada $-4 \mathrm{~h}-$, seguida de batelada $-4 \mathrm{~h}$ ), 41 dias (ensaio em batelada alimentada $-6 \mathrm{~h}-$, seguida de batelada $-2 \mathrm{~h}$ ) e 35 dias (ensaio em batelada alimentada - 8 h). O sistema em estudo foi operado durante 218 dias ininterruptos.

O monitoramento do reator foi feito por amostras do afluente e do efluente, através das análises de concentrações de substrato, de alcalinidade parcial (AP), de alcalinidade intermediária (AI), de alcalinidade total (AT), de alcalinidade a bicarbonato (AB), de ácidos voláteis (AVT), de sólidos totais (ST), de sólidos totais voláteis (STV), de sólidos suspensos totais (SST) e de sólidos suspensos voláteis (SSV), além do acompanhamento do $\mathrm{pH}$ e do volume descarregado. Ressalta-se que as análises de concentrações de substrato foram feitas diariamente e que as demais variáveis foram monitoradas com uma freqüência de duas vezes por semana.

\subsubsection{Obtenção dos perfis ao longo do ciclo}

Depois de atingida a estabilidade operacional, ou seja, a apresentação de valores aproximadamente constantes para as medições feitas no monitoramento, foram obtidos perfis de algumas das variáveis, através da retirada de amostras ao longo do tempo de operação de um ciclo. As concentrações de substrato na forma filtrada, de biogás, de alcalinidade a bicarbonato e de ácidos voláteis totais foram as variáveis de interesse. Esses perfis possibilitaram uma melhor compreensão das rotas 
de degradação ao longo de um ciclo, além de permitirem a estimativa de parâmetros cinéticos de degradação da matéria orgânica.

As amostras retiradas para obtenção dos perfis anteriormente citados foram coletadas em intervalos de tempo diferentes para cada perfil, a fim de que o volume total das amostras coletadas não excedesse $250 \mathrm{~mL}$, ou seja, menos de $10 \%$ do volume alimentado de substrato.

Considerando-se que o reator é operado em três ciclos diários, com 8 horas cada, foram adotados os seguintes procedimentos nas amostragens de perfis de concentração de matéria orgânica: (a) A contagem do tempo foi iniciada após os 13 minutos, uma vez que o carregamento do sistema é feito durante 10 minutos e que um tempo de 3 minutos é suficiente para a completa homogeneização do meio. (b) Foram adotados intervalos de 15 minutos entre as amostragens até a $3^{\text {a }}$ hora do ciclo e a partir de então, intervalos de 30 minutos até a descarga do sistema. O volume de cada amostra correspondeu a $7 \mathrm{~mL}$. (c) Os valores de concentração de matéria orgânica dos perfis foram normalizados, considerando-se como base a concentração média para os três ciclos no início da batelada e as eficiências relativas a cada amostragem durante o ciclo.

Para a obtenção dos perfis de biogás foram adotados os mesmos intervalos de tempo descritos. Durante esse tipo de amostragem, após a verificação da ausência de vazamentos, injetava-se nitrogênio gasoso, durante 3 minutos no sistema, afim de que as quantidades de biogás produzidas no ciclo anterior fossem expulsas. A retirada de biogás foi feita com a seringa Supelco ${ }^{\circledR}(1 \mathrm{~mL}$ para cada amostragem).

Para a medição dos perfis das variáveis concentrações de AB e AVT, feitas por titulometria, foram adotados nas primeiras condições testadas intervalos de 30 
minutos entre as amostragens e a partir da estratégia de alimentação batelada alimentada (4 h) seguida de batelada (4 h) foram adotados intervalos de 40 minutos. Cada retirada correspondia a $20 \mathrm{~mL}$.

\subsubsection{Análise dos sólidos presentes na espuma de poliuretano}

Após a obtenção dos perfis, amostras de biopartículas de espuma de poliuretano eram retiradas do reator para análise microbiológica e uma limpeza do sistema era efetuada, retirando-se o material polimérico eventualmente presente. Com a pesagem do suporte com a biomassa aderida, o cálculo da relação $\mathrm{mgSVT} / \mathrm{g}$ de espuma de poliuretano era então realizado, de acordo com o seguinte procedimento:

(i) O biofilme formado (espuma de poliuretano contendo microrganismos imobilizados) era pesado, obtendo-se a massa total $\left(\mathrm{m}_{\mathrm{T}}\right)$. Uma pequena amostra da espuma (cubos) era retirada do leito e pesada $\left(\mathrm{m}_{\mathrm{esp}}{ }^{\text {inoc }}\right)$.

(ii) Os cubos eram lavados com água destilada e alocados em uma cápsula de porcelana de $35 \mathrm{~mL}$. O resíduo da lavagem (sólidos desprendidos e água) eram depositados em uma cápsula de porcelana de $50 \mathrm{~mL}$. A massa das cápsulas era previamente conhecida.

(iii) Após o período de $24 \mathrm{~h}$ em um forno a $105{ }^{\circ} \mathrm{C}$, as cápsulas eram pesadas. A diferença na pesagem correspondia ao peso da espuma limpa, $\mathrm{m}_{\mathrm{esp}}^{\text {limpa }}$ (cápsula de $35 \mathrm{~mL}$ ) e aos valores de sólidos totais para a amostra (cápsula de $50 \mathrm{~mL}$ ). A cápsula de $50 \mathrm{~mL}$ era submetida a uma temperatura de $550{ }^{\circ} \mathrm{C}$, em um forno tipo mufla durante $2 \mathrm{~h}$. 
(iv) A diferença entre a pesagem anterior a esta etapa e a massa da cápsula após o aquecimento na mufla correspondia a concentração de sólidos voláteis totais (SVT) para a amostra.

(v) Através da relação entre a massa de espuma inoculada e massa de espuma limpa $\left(\mathrm{m}_{\mathrm{esp}}{ }^{\mathrm{inoc}} / \mathrm{m}_{\mathrm{esp}}\right.$ limpa , e da massa total do leito $\left(\mathrm{m}_{\mathrm{T}}\right)$ era feito o cálculo da massa total de espuma limpa $\left(\mathrm{m}_{\Gamma}^{\text {limpa }}\right)$ e dessa maneira as concentrações de sólidos por massa de espuma limpa e sólidos por volume de água residuária tratada eram obtidas.

\subsubsection{Análise dos resultados experimentais}

Os resultados experimentais obtidos no monitoramento do sistema e nos perfis ao longo do ciclo em cada condição operacional, ou seja, com diferentes períodos de enchimento do reator, foram analisados com base nos princípios da digestão anaeróbia, avaliando-se a influência da estratégia de alimentação sobre a estabilidade e desempenho do sistema, com atenção especial aos ácidos graxos voláteis, intermediários no processo de conversão da matéria orgânica a biogás.

Os parâmetros cinéticos obtidos nos perfis ao longo do ciclo foram analisados com base nas velocidades de conversão da matéria orgânica, obtidas através de ajustes matemáticos às curvas transientes.

As análises microbiológicas foram úteis para a avaliação das mudanças na ecologia microbiana à medida que se altera a estratégia de alimentação.

Os resultados obtidos foram comparados com os dados do trabalho de RATUSZNEI et al. (2003), no qual foi realizado um protocolo experimental 
semelhante, mas o leito contendo a biomassa imobilizada não ficava submerso com água residuária, o que acreditou-se ser um dos motivos do desempenho reduzido e da instabilidade do sistema. Essa analogia permitiu, portanto, que um estudo mais detalhado da influência da estratégia de alimentação em reator ASBR contendo biomassa imobilizada fosse realizado. 


\section{CAPÍtULO 5}

\section{RESULTADOS E DISCUSSÃO}

\subsection{Operação e perfis de desempenho ao longo do ciclo para diferentes estratégias de alimentação}

\subsubsection{Ensaio preliminar em batelada $(8$ h) para a verificação do funcionamento do sistema e ajustes operacionais}

Após a montagem da aparelhagem experimental e a imobilização do lodo anaeróbio, a operação do reator foi iniciada. O ensaio preliminar foi realizado com o objetivo de se verificar o funcionamento do sistema, com a execução de ajustes operacionais, quando necessários. Nessa condição o sistema foi operado por 30 dias e os valores médios das variáveis monitoradas estão contidos na Tabela 5.1. 
TABELA 5.1: Valores médios das variáveis monitoradas no ensaio preliminar em batelada (8 h).

\begin{tabular}{ccc}
\hline Variável & Afluente $^{(a)}$ & Efluente $^{(a)}$ \\
\hline $\mathrm{C}_{\mathrm{ST}}(\mathrm{mgDQO} / \mathrm{L})$ & $489 \pm 17^{(20)}$ & $192 \pm 56^{(22)}$ \\
$\mathrm{C}_{\mathrm{SF}}(\mathrm{mgDQO} / \mathrm{L})$ & - & $147 \pm 48^{(22)}$ \\
$\varepsilon_{\mathrm{ST}}(\%)$ & - & $61 \pm 12^{(22)}$ \\
$\varepsilon_{\mathrm{SF}}(\%)$ & $70 \pm 10^{(22)}$ \\
$\mathrm{AVT}(\mathrm{mgHAc} / \mathrm{L})$ & $32 \pm 7^{(9)}$ & $45 \pm 34^{(7)}$ \\
$\mathrm{AB}(\mathrm{mgCaCO} / \mathrm{L})$ & $122 \pm 12^{(9)}$ & $215 \pm 91^{(7)}$ \\
$\mathrm{AI} / \mathrm{AP}$ & $0,25 \pm 0,02^{(9)}$ & $0,32 \pm 0,19^{(7)}$ \\
$\mathrm{pH}$ & $8,9 \pm 0,1^{(9)}$ & $7,4 \pm 0,2^{(7)}$ \\
$\mathrm{V}$ olume (L) & - & $2,21 \pm 0,58^{(21)}$ \\
$\mathrm{ST}(\mathrm{mg} / \mathrm{L})$ & $882 \pm 54^{(5)}$ & $707 \pm 142^{(5)}$ \\
$\mathrm{SVT}(\mathrm{mg} / \mathrm{L})$ & $482 \pm 56^{(5)}$ & $275 \pm 146^{(5)}$ \\
$\mathrm{SST}(\mathrm{mg} / \mathrm{L})$ & $30 \pm 18^{(5)}$ & $65 \pm 31^{(5)}$ \\
$\mathrm{SSV}(\mathrm{mg} / \mathrm{L})$ & $22 \pm 7^{(5)}$ & $34 \pm 16^{(5)}$ \\
\hline${ }^{(9)}$ Em parênteses o número de amostragens consideradas no cálculo da média. &
\end{tabular}

As Figuras 5.1 e 5.2 mostram respectivamente os valores de concentrações de matéria orgânica das amostras de efluente e as eficiências de remoção obtidas. Os dados de operação nessa condição estão contidos no Apêndice II para o afluente e no Apêndice III para o efluente do reator. 


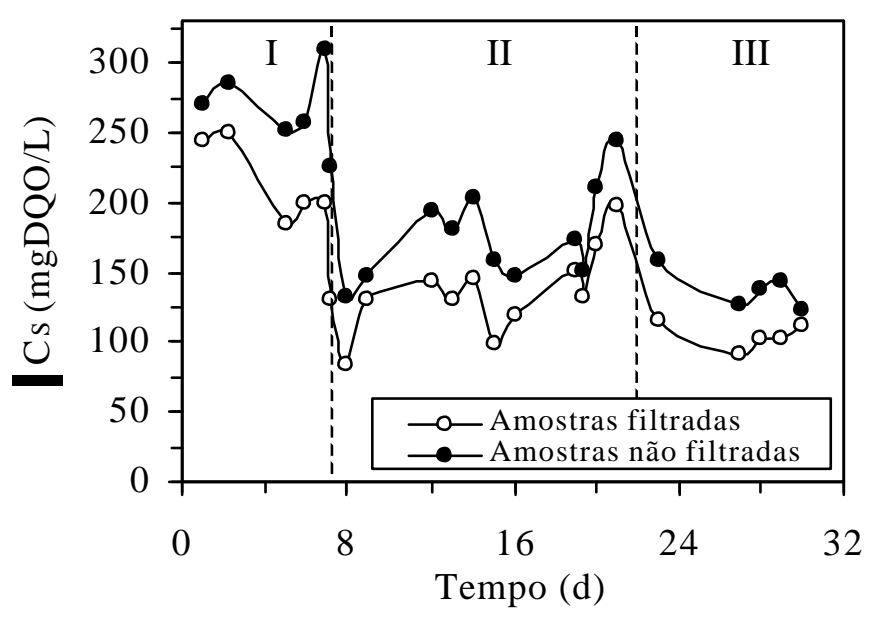

FIGURA 5.1: Concentração de matéria orgânica, em termos de DQO, durante o ensaio preliminar em batelada $(8 \mathrm{~h})$.

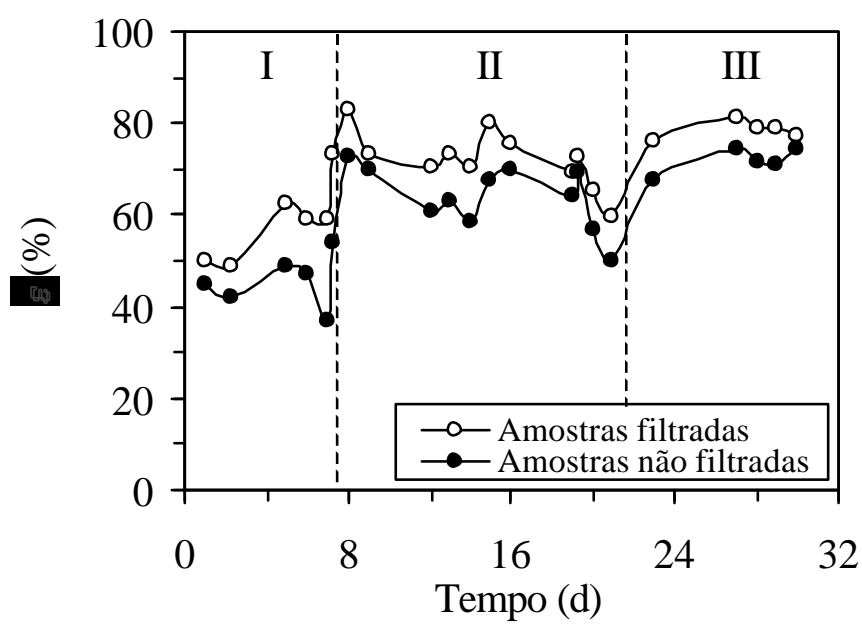

FIGURA 5.2: Eficiência de remoção de matéria orgânica obtida no ensaio preliminar em batelada $(8 \mathrm{~h})$.

A baixa eficiência apresentada pelo sistema no decorrer das primeiras semanas levou à mudança de algumas condições de operação, a fim de se avaliar a resposta do reator. Após a primeira semana de operação, verificou-se que o inóculo 
usado não apresentou bons resultados (trecho I das Figuras 5.1 e 5.2). A biomassa inoculada havia perdido a viabilidade metabólica devido ao longo período de resfriamento (inatividade) a que foi submetida. A alta concentração de ácidos voláteis no efluente (Figura 5.4) indicava que outra inoculação seria necessária. O novo inóculo utilizado também provinha do mesmo abatedouro de aves, entretanto a sua coleta era recente.

Decorridas duas semanas observou-se a tendência de estabilização em baixas eficiências, na ordem de $72 \%$ e $64 \%$ para amostras de efluente filtradas e não filtradas, respectivamente (trecho II das Figuras 5.1 e 5.2).

Optou-se então pela diminuição do volume tratado, a fim de que a conversão de matéria orgânica fosse favorecida (trecho III das Figuras 5.1 e 5.2). Apesar da melhora no desempenho, registrourse a formação de polímeros extracelulares no reator. Notou-se que o biogás gerado não se desprendia com facilidade, acarretando na diminuição do volume útil no cesto onde a biomassa imobilizada foi alocada. A remoção de parte da espuma foi efetuada e no $30 .^{\circ}$ dia de operação, o impelidor usado na agitação do reator foi rebaixado, de modo a obedecer aos parâmetros de Rushton (1/3 da altura do meio contendo a biomassa). Dessa maneira, as condições propostas para a realização do ensaio em batelada (volume tratado de 2,5 L, agitação de $500 \mathrm{rpm}$ e ciclos de $8 \mathrm{~h}$ ) foram definitivamente estabelecidas.

As Figuras 5.3 e 5.4 mostram os valores de alcalinidade a bicarbonato e de ácidos voláteis totais, respectivamente. O monitoramento dessas variáveis forneceu subsídios para a análise da estabilidade do sistema durante os ensaios preliminares. 


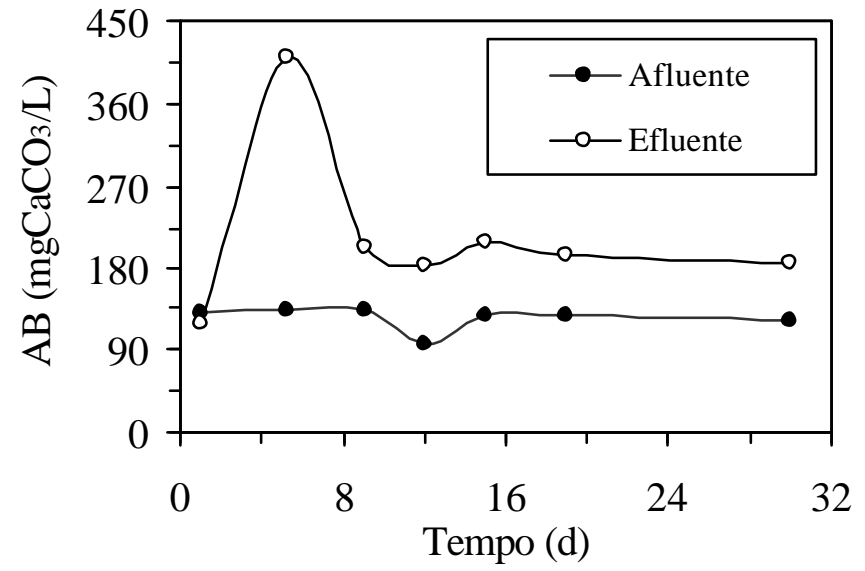

FIGURA 5.3: Alcalinidade a bicarbonato durante o ensaio preliminar em batelada $(8 \mathrm{~h})$.

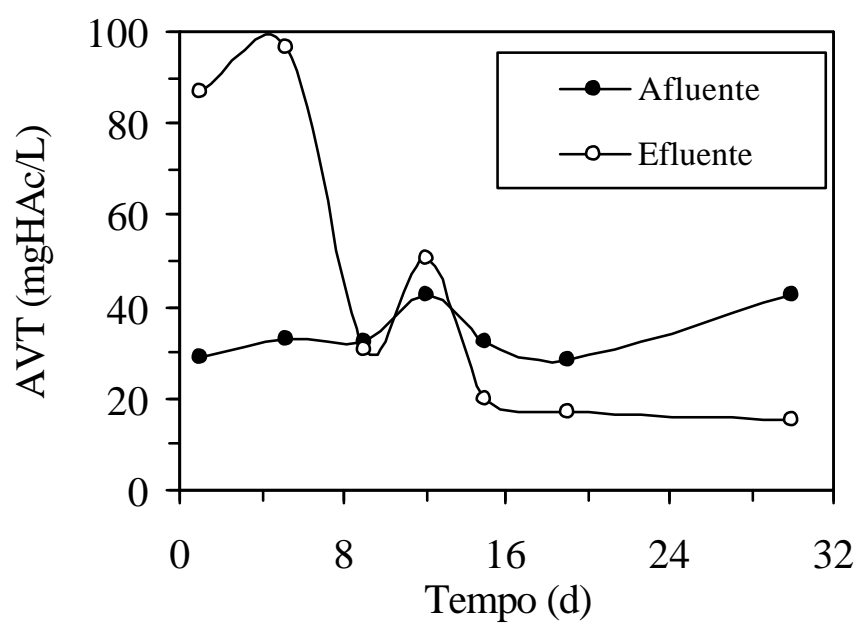

FIGURA 5.4: Concentração de ácidos voláteis totais durante o ensaio preliminar em batelada $(8 \mathrm{~h})$. 


\subsubsection{Operação do reator em batelada $(8$ h)}

Durante esse ensaio, o reator foi operado em batelada, com tempo de enchimento total de 10 minutos. Os valores médios das variáveis monitoradas estão contidos na Tabela 5.2.

TABELA 5.2: Valores médios das variáveis monitoradas no ensaio em batelada $(8 \mathrm{~h})$.

\begin{tabular}{|c|c|c|}
\hline Variável & Afluente $^{(a)}$ & Efluente $^{(a)}$ \\
\hline $\mathrm{C}_{\mathrm{ST}}(\mathrm{mgDQO} / \mathrm{L})$ & $497 \pm 26^{(20)}$ & $152 \pm 18^{(20)}$ \\
\hline $\mathrm{C}_{\mathrm{SF}}(\mathrm{mgDQO} / \mathrm{L})$ & - & $109 \pm 18^{(20)}$ \\
\hline$\varepsilon_{S T}(\%)$ & - & $70 \pm 4^{(20)}$ \\
\hline$\varepsilon_{\mathrm{SF}}(\%)$ & - & $78 \pm 4^{(20)}$ \\
\hline AVT (mgHAc/L) & $27 \pm 3^{(6)}$ & $18 \pm 4^{(9)}$ \\
\hline $\mathrm{AB}\left(\mathrm{mgCaCO}_{3} / \mathrm{L}\right)$ & $113 \pm 3^{(6)}$ & $192 \pm 5^{(9)}$ \\
\hline AI/AP & $0,21 \pm 0,04^{(6)}$ & $0,22 \pm 0,04^{(9)}$ \\
\hline $\mathrm{pH}$ & $8,7 \pm 0,2^{(6)}$ & $7,3 \pm 0,2^{(9)}$ \\
\hline Volume (L) & - & $2,46 \pm 0,43^{(20)}$ \\
\hline $\mathrm{ST}(\mathrm{mg} / \mathrm{L})$ & $863 \pm 106^{(5)}$ & $687 \pm 145^{(5)}$ \\
\hline $\mathrm{SVT}(\mathrm{mg} / \mathrm{L})$ & $500 \pm 116^{(5)}$ & $317 \pm 139^{(5)}$ \\
\hline $\mathrm{SST}(\mathrm{mg} / \mathrm{L})$ & $29 \pm 16^{(5)}$ & $48 \pm 14^{(5)}$ \\
\hline $\mathrm{SSV}(\mathrm{mg} / \mathrm{L})$ & $20 \pm 13^{(5)}$ & $32 \pm 14^{(5)}$ \\
\hline
\end{tabular}


Os resultados obtidos durante os 29 dias de operação foram utilizados como padrão comparativo em relação as diferentes estratégias de alimentação realizadas, de acordo com a proposta de trabalho. As Figuras 5.5 e 5.6 mostram respectivamente os valores de concentrações de matéria orgânica das amostras de efluente e as eficiências de remoção obtidas, enquanto as Figuras 5.7 e 5.8 mostram a alcalinidade a bicarbonato e ácidos voláteis totais monitoradas durante o ensaio.

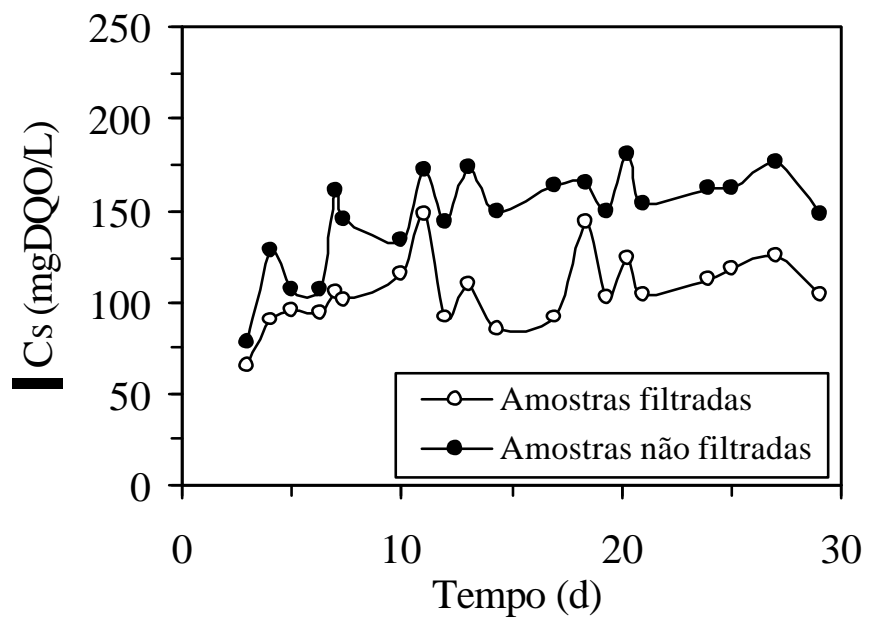

FIGURA 5.5: Concentração de matéria orgânica, em termos de DQO, para a operação em batelada $(8 \mathrm{~h})$. 


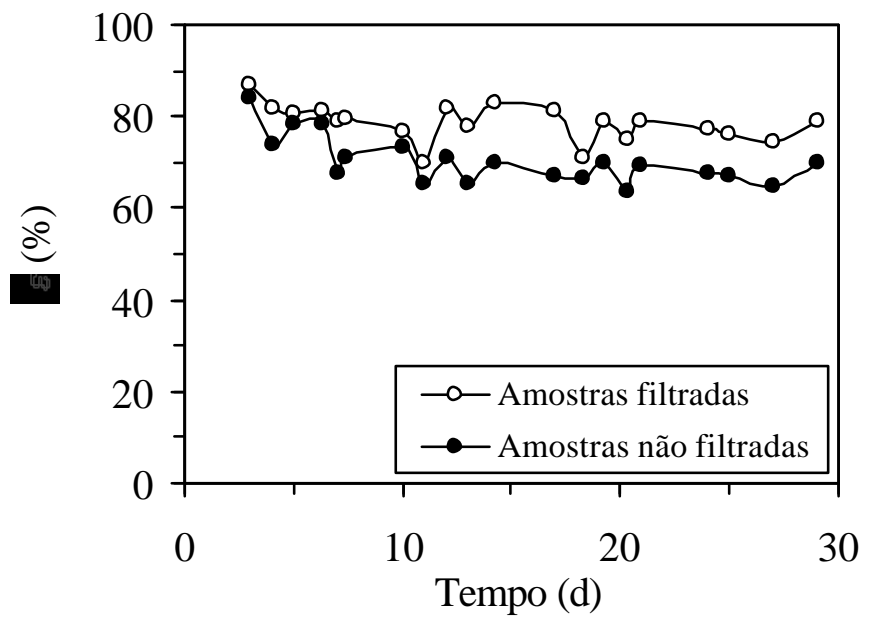

FIGURA 5.6: Eficiência de remoção de matéria orgânica obtida no ensaio em batelada $(8 \mathrm{~h})$.

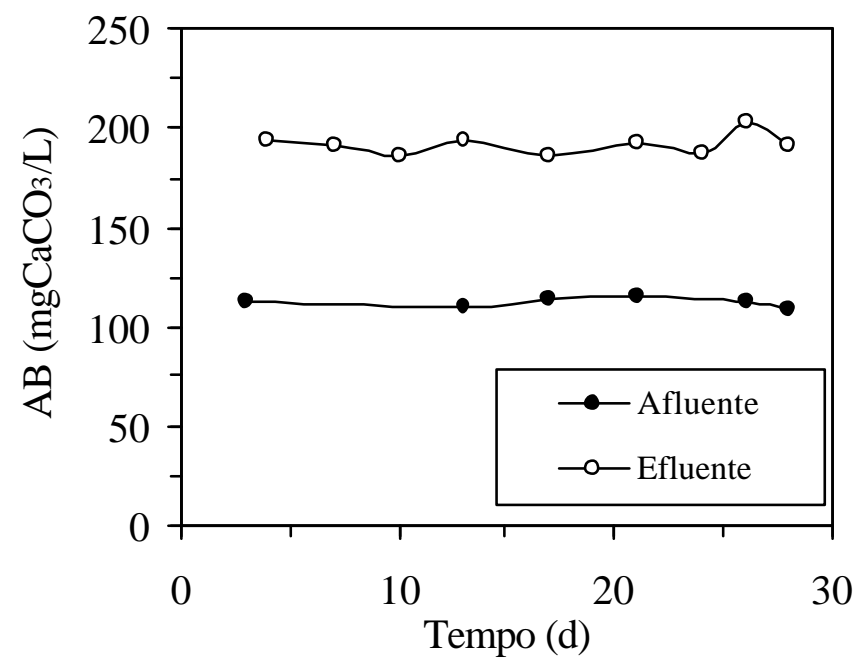

FIGURA 5.7: Alcalinidade a bicarbonato durante o ensaio em batelada ( $8 \mathrm{~h})$. 


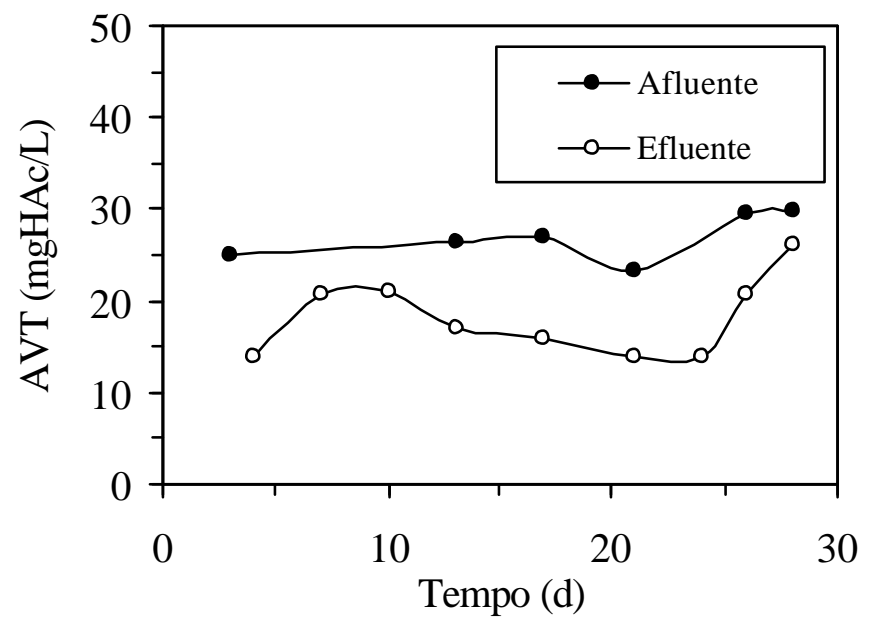

FIGURA 5.8: Concentração de ácidos voláteis totais durante o ensaio em batelada $(8 \mathrm{~h})$.

A análise da Tabela 5.2 permite verificar que a eficiência média de remoção de matéria orgânica registrada (78 \% para amostras filtradas) se situa no mesmo patamar alcançado por sistemas similares tratando água residuária sintética. O valor médio de $70 \%$ de remoção, considerando-se amostras não filtradas se deve ao fato de que a carga orgânica volumétrica aplicada (1500 mgDQO/L.d) possui um valor significativo, considerando-se que o cesto onde a biomassa foi alocada ocupa aproximadamente a metade do reator. Percebe-se dessa maneira, que a quantidade de biomassa presente no sistema é menor se comparada a outras configurações. A presença de material viscoso polimérico de origem biológica, acumulado no reator ao longo do ensaio, influiu na concentração de matéria orgânica não filtrada; esse fato é especialmente verificado se observarmos os valores de SVT $(317 \pm 139 \mathrm{mg} / \mathrm{L})$ no efluente. 
A estabilidade do sistema é confirmada pelos baixos valores de concentração de ácidos voláteis totais e pela geração de alcalinidade a bicarbonato. Os baixos valores de desvio padrão e a relação AI/AP no afluente e no efluente também podem ser citados como indicativos de estabilidade. Observa-se que o tempo demandado para que o sistema se mostrasse estável foi de aproximadamente 10 dias e que esse período curto se deve à realização dos ensaios preliminares para ajustes operacionais, que se estenderam por 30 dias. Os dados de operação nessa condição estão contidos no Apêndice II para o afluente e no Apêndice III para o efluente do reator.

Os perfis de remoção de matéria orgânica ao longo do tempo de batelada foram obtidos com o monitoramento dos valores em três dias diferentes, com o sistema estabilizado. A Figura 5.9 apresenta os resultados alcançados nos ciclos de número $73\left(25 .^{\circ}\right.$ dia), 79 (27. ${ }^{\circ}$ dia $)$ e $85\left(29 .^{\circ}\right.$ dia).

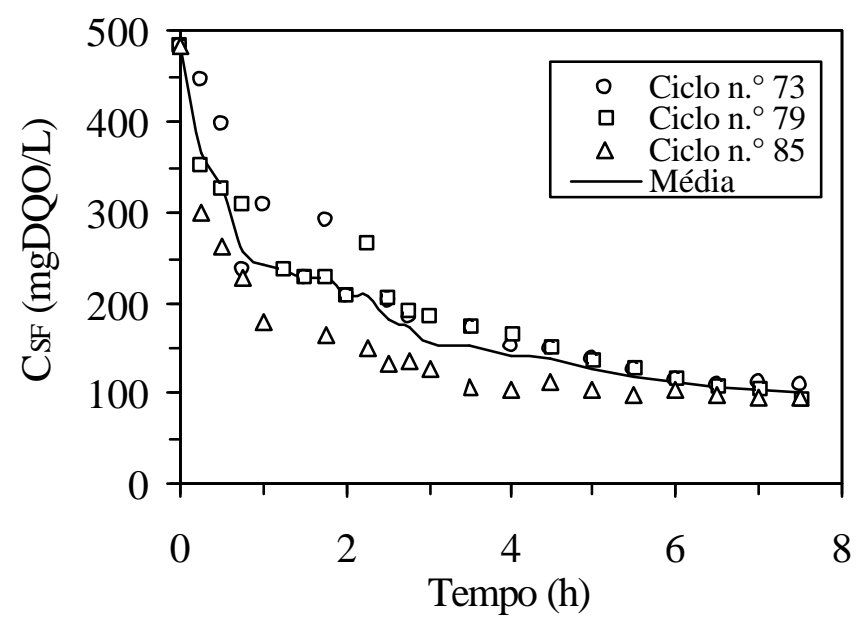

FIGURA 5.9: Perfis de concentração de substrato ao longo da batelada (8 h). 
Os perfis de alcalinidade a bicarbonato e de ácidos voláteis totais foram realizados em duplicata, no $26 .^{\circ}$ e no $28 .^{\circ}$ dias (ciclos $n^{\circ} 76$ e 82$)$ e são visualizados nas Figuras 5.10 e 5.11.

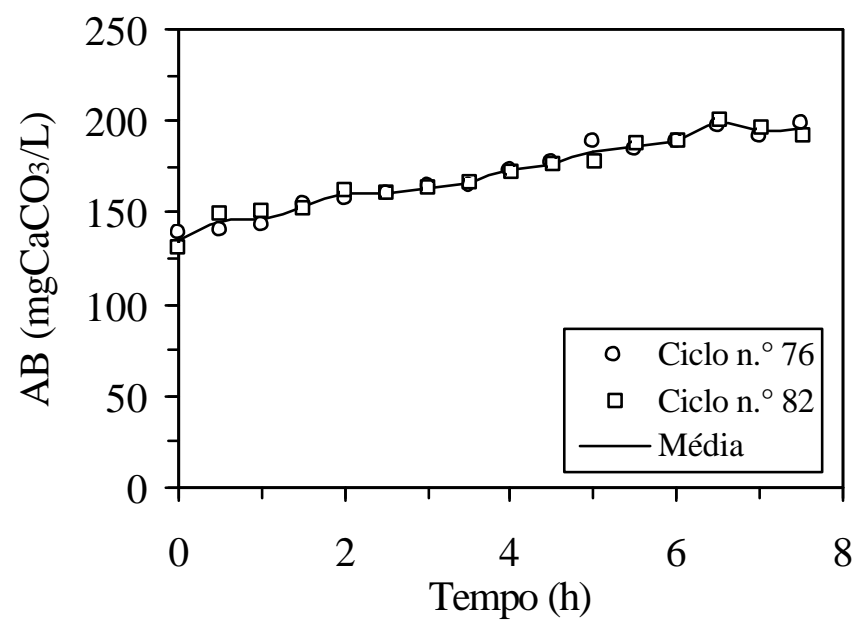

FIGURA 5.10: Perfis de alcalinidade a bicarbonato ao longo da batelada ( $8 \mathrm{~h})$. 


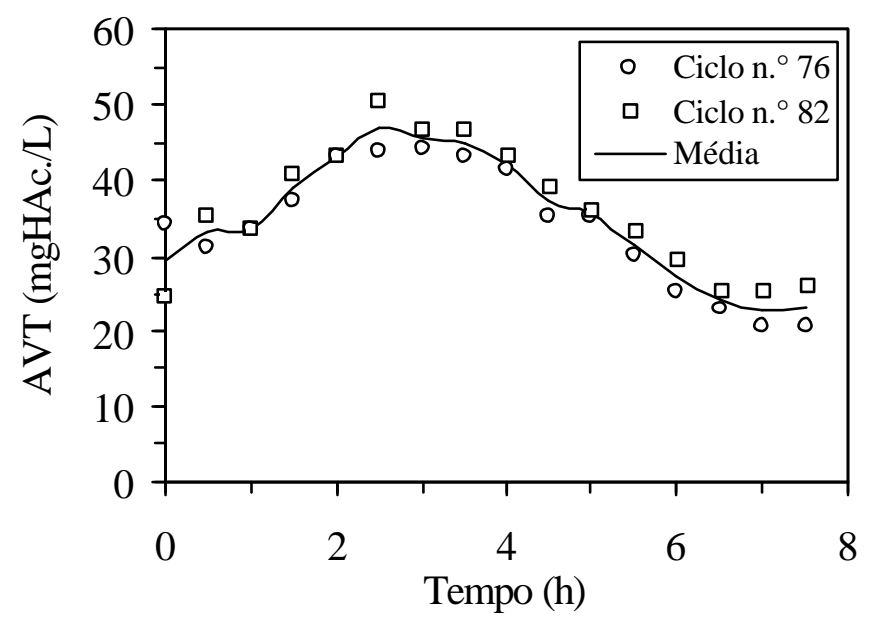

FIGURA 5.11: Perfis de concentração de ácidos voláteis totais ao longo da batelada $(8 \mathrm{~h})$.

Os resultados obtidos indicam que o balanço entre produção e consumo de ácidos orgânicos voláteis, nas primeiras 2,5 horas da etapa de reação, não afetam o pH do meio, uma vez que a concentração de alcalinidade a bicarbonato nesse intervalo de tempo, se mantem em valores que garantem o tamponamento do sistema. O processo de digestão da matéria orgância completa-se nas etapas de acetogênese e metanogênse, com o consumo dos ácidos orgânicos voláteis produzidos na acidogênese e com a produção de $\mathrm{CH}_{4}$ e $\mathrm{CO}_{2}$.

Ressalta-se que os dados referentes aos perfis obtidos estão tabulados no Apêndice IV. 


\subsubsection{Operação do reator em batelada alimentada $\left(\begin{array}{ll}2 & h\end{array}\right)$ seguida de batelada $(6 \mathrm{~h})$}

Após a finalização do ensaio em batelada, usado como padrão comparativo em relação às diversas estratégias de alimentação propostas, iniciou-se a operação do reator operado em batelada alimentada seguida de batelada. O carregamento do sistema foi feito através de duas bombas, controladas por temporizadores. $\mathrm{O}$ reator foi carregado até a cota do cesto de aço inoxidável onde a biomassa imobilizada em espuma de poliuretano foi alocada; este volume correspondia a 1,5 L, e o carregamento durava 10 minutos. Após esse período, uma alimentação adicional de 1 L era efetuada, sendo que essa alimentação era feita uniformemente durante 2 horas. Essa estratégia caracterizou a operação do reator em batelada alimentada (1/4 do ciclo), seguida de batelada.

O ensaio foi realizado em 42 dias e os valores médios das variáveis monitoradas estão contidos na Tabela 5.3. A Tabela 5.4 apresenta os dados de concentração dos sólidos relativos à biomassa imobilizada contida no reator (massa de sólidos em questão por unidade de massa do suporte inerte, e massa de sólidos por volume alimentado). 
TABELA 5.3: Valores médios das variáveis monitoradas no ensaio em batelada alimentada (2 h) seguida de batelada (6 h).

\begin{tabular}{|c|c|c|}
\hline Variável & Afluente $^{(a)}$ & Efluente $^{(a)}$ \\
\hline $\mathrm{C}_{\mathrm{ST}}(\mathrm{mgDQO} / \mathrm{L})$ & $533 \pm 43^{(30)}$ & $155 \pm 25^{(26)}$ \\
\hline $\mathrm{C}_{\mathrm{SF}}(\mathrm{mgDQO} / \mathrm{L})$ & - & $101 \pm 10^{(26)}$ \\
\hline$\varepsilon_{\mathrm{ST}}(\%)$ & - & $71 \pm 5^{(26)}$ \\
\hline$\varepsilon_{\mathrm{SF}}(\%)$ & - & $81 \pm 2^{(26)}$ \\
\hline AVT (mgHAc/L) & $28 \pm 3^{(9)}$ & $21 \pm 6^{(10)}$ \\
\hline $\mathrm{AB}\left(\mathrm{mgCaCO}_{3} / \mathrm{L}\right)$ & $119 \pm 8^{(9)}$ & $184 \pm 14^{(10)}$ \\
\hline AI/AP & $0,19 \pm 0,04^{(9)}$ & $0,22 \pm 0,05^{(10)}$ \\
\hline $\mathrm{pH}$ & $8,4 \pm 0,8^{(9)}$ & $7,4 \pm 0,1$ \\
\hline Volume (L) & - & $2,50 \pm 0,05^{(22)}$ \\
\hline $\mathrm{ST}(\mathrm{mg} / \mathrm{L})$ & $945 \pm 118^{(7)}$ & $688 \pm 53^{(7)}$ \\
\hline $\mathrm{SVT}(\mathrm{mg} / \mathrm{L})$ & $484 \pm 56^{(7)}$ & $266 \pm 79^{(7)}$ \\
\hline $\mathrm{SST}(\mathrm{mg} / \mathrm{L})$ & $49 \pm 16^{(7)}$ & $55 \pm 22^{(7)}$ \\
\hline $\mathrm{SSV}(\mathrm{mg} / \mathrm{L})$ & $29 \pm 15^{(7)}$ & $32 \pm 15^{(7)}$ \\
\hline
\end{tabular}


TABELA 5.4: Valores dos sólidos da biomassa imobilizada (inóculo) contida no reator operado em batelada alimentada $(2 \mathrm{~h})$ seguida de batelada $(6 \mathrm{~h})$.

\begin{tabular}{cc}
\hline Parâmetro & Inóculo \\
\hline ST $(\mathrm{mg} / \mathrm{g})^{(a)}$ & 1164 \\
$\mathrm{SVT}(\mathrm{mg} / \mathrm{g})^{(a)}$ & 1018 \\
$\mathrm{ST}(\mathrm{g} / \mathrm{L})^{(b)}$ & 7,3 \\
$\mathrm{SVT}(\mathrm{g} / \mathrm{L})^{(b)}$ & 6,4 \\
$\mathrm{SVT} / \mathrm{ST}$ & 0,87 \\
& \\
\hline $\begin{array}{l}\left({ }^{(a)}(\mathrm{mg} \text { de sólidos/g de espuma de poliuretano). }\right. \\
\left({ }^{(b)}(\mathrm{g} \text { de sólidos/L de volume de água residuária tratada). }\right.\end{array}$
\end{tabular}

Através da análise da Tabela 5.4, conclui-se que $87 \%$ dos sólidos totais no suporte utilizado são sólidos voláteis. Os valores da concentração de biomassa, representados como concentração de sólidos totais e sólidos voláteis totais dentro do reator, foram obtidos a partir da quantidade média de biomassa por espuma: sabendose a quantidade de espuma no reator, determina-se a concentração de biomassa por volume útil do reator. Cabe lembrar que nesse sistema, o volume útil é igual ao volume alimentado no reator.

As Figuras 5.12 e 5.13 mostram respectivamente os valores de concentrações de matéria orgânica das amostras de efluente e as eficiências de remoção obtidas no período, enquanto as Figuras 5.14 e 5.15 ilustram os valores de alcalinidade a bicarbonato e de concentrações de ácidos voláteis totais monitoradas durante o ensaio. Os dados de operação nessa condição estão contidos no Apêndice II para o afluente e no Apêndice III para o efluente do reator. 


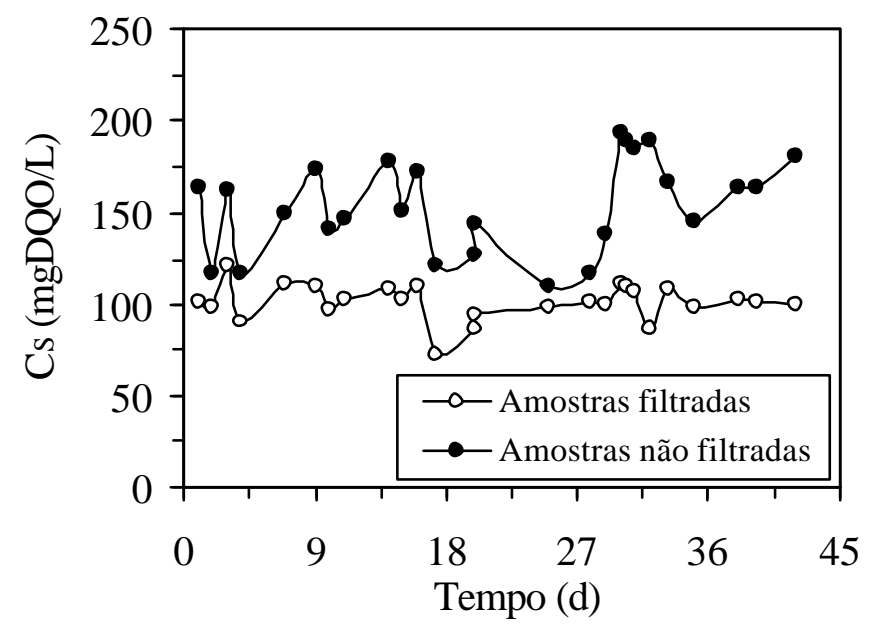

FIGURA 5.12: Concentração de matéria orgânica, em termos de DQO, para a operação em batelada alimentada (2 h) seguida de batelada $(6 \mathrm{~h})$.

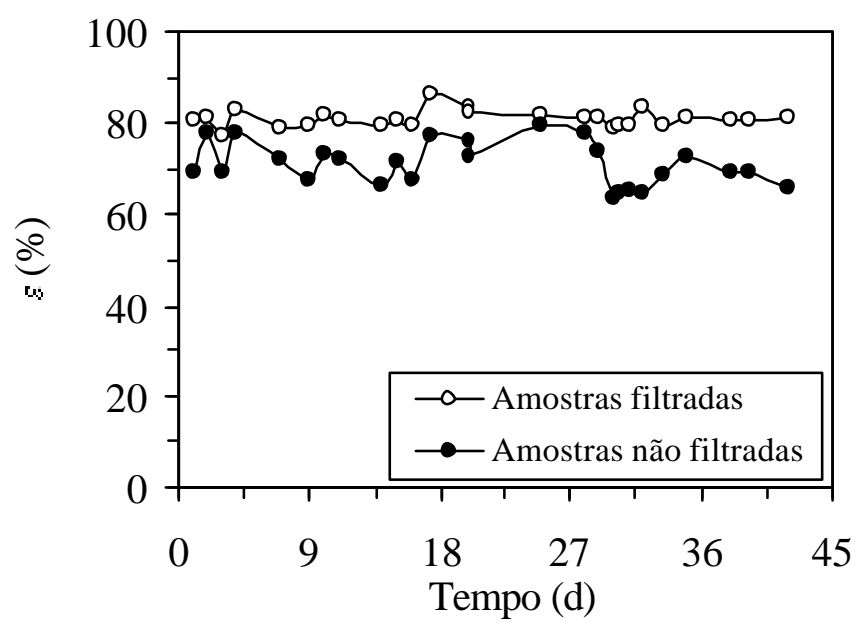

FIGURA 5.13: Eficiência de remoção de matéria orgânica obtida no ensaio em batelada alimentada ( $2 \mathrm{~h})$ seguida de batelada (6 h). 


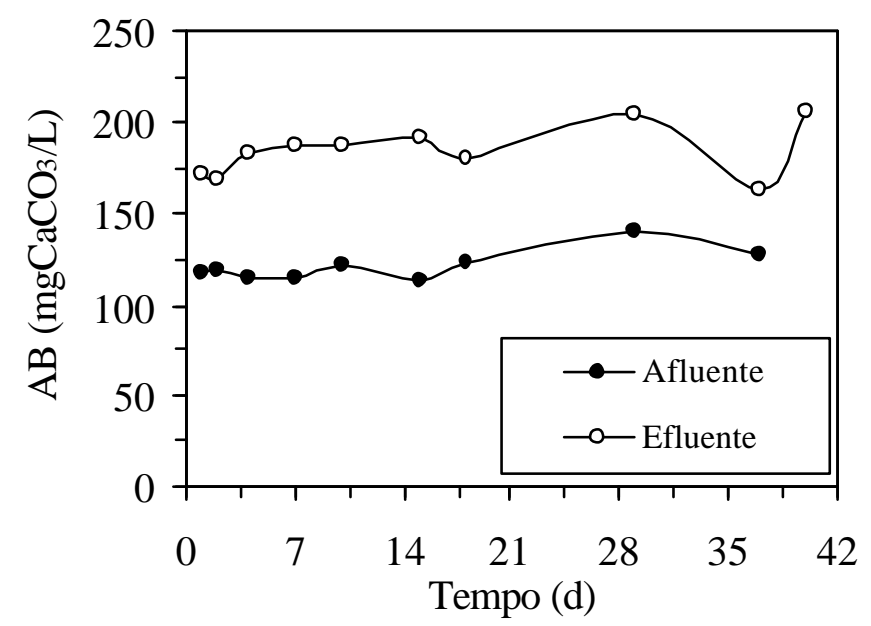

FIGURA 5.14: Alcalinidade a bicarbonato durante o ensaio em batelada alimentada (2 h) seguida de batelada (6 h).

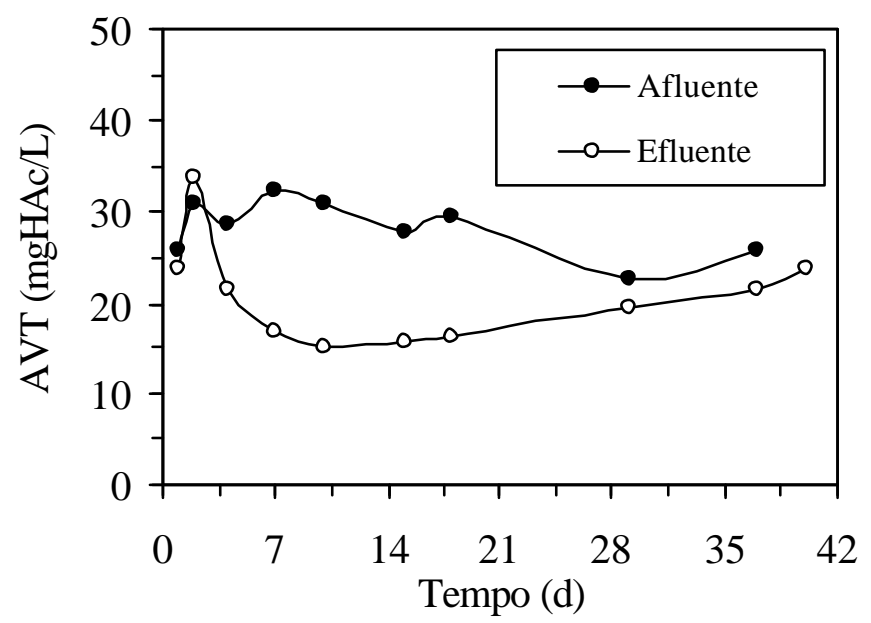

FIGURA 5.15: Concentração de ácidos voláteis totais durante o ensaio em batelada alimentada (2 h) seguida de batelada (6 h).

Em relação à eficiência do sistema, pode-se concluir que o tempo de enchimento mais longo (2 h), não afetou o desempenho do reator. Os valores médios para remoção de matéria orgânica no período foram de $81 \%$ e $71 \%$, para amostras 
filtradas e não filtradas respectivamente. A análise da Figura 5.12 permite verificar que os valores de concentração de matéria orgânica efluente se estabilizaram na primeira semana de operação, indicando uma boa adaptação do sistema à nova estratégia de alimentação.

Os valores de concentração de ácidos voláteis totais se mantiveram baixos (média de $21 \mathrm{mHAc} / \mathrm{L}$ no efluente) e constatourse geração de alcalinidade a bicarbonato em todo o período (média de $121 \mathrm{mgCaCO}_{3} / \mathrm{L}$ em intervalos de 115 a $140 \mathrm{mgCaCO}_{3} / \mathrm{L}$ no afluente e média de $184 \mathrm{mgCaCO}_{3} / \mathrm{L}$ em intervalos de 164 a 206 mgCaCO3/L no efluente). Os valores de $\mathrm{pH}$ registrados (intervalos de 7,2 a 7,7 no efluente), também podem ser citados como indicativo de estabilidade.

Os perfis de remoção de matéria orgânica ao longo do tempo de batelada foram obtidos de maneira análoga a primeira condição, e são visualizados na Figura 5.16. As amostragens foram realizadas no $31 .^{\circ}, 34 .^{\circ}$ e $40 .^{\circ}$ dias.

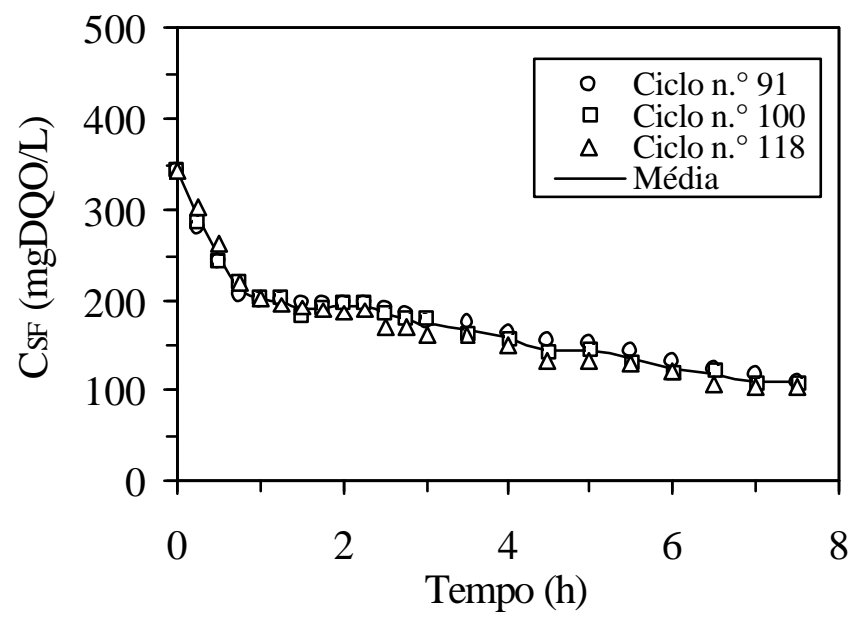

FIGURA 5.16: Perfis de concentração de substrato ao longo da batelada alimentada (2 h) seguida de batelada (6 h). 
A operação do reator nessa condição modifica o comportamento dos perfis de conversão de matéria orgânica, de alcalinidade a bicarbonato e concentrações de ácidos voláteis. A alimentação, realizada em um período maior ( 2 h) não permite o acúmulo de ácidos voláteis em grande quantidade, uma vez que a alternância entre condições de fartura e escassez de substrato não é tão pronunciada, como observado na operação em batelada convencional. As Figuras 5.17 e 5.18 ilustram os perfis de $\mathrm{AB}$ e AVT, respectivamente. As amostragens foram feitas nos dias de número $38 \mathrm{e}$ 41 do período de ensaio.

Perfis de composição do biogás foram obtidos no $33 .^{\circ}, 39 .^{\circ}$ e $43 .^{\circ}$ dias. As Figuras 5.19 e 5.20 mostram as concentrações de metano e dióxido de carbono, respectivamente, e a Figura 5.21 ilustra a média das frações molares, para as três amostragens realizadas, de $\mathrm{CH}_{4}$ e $\mathrm{CO}_{2}$. Os valores percentuais foram calculados considerando-se que o biogás era composto apenas pelos gases monitorados.

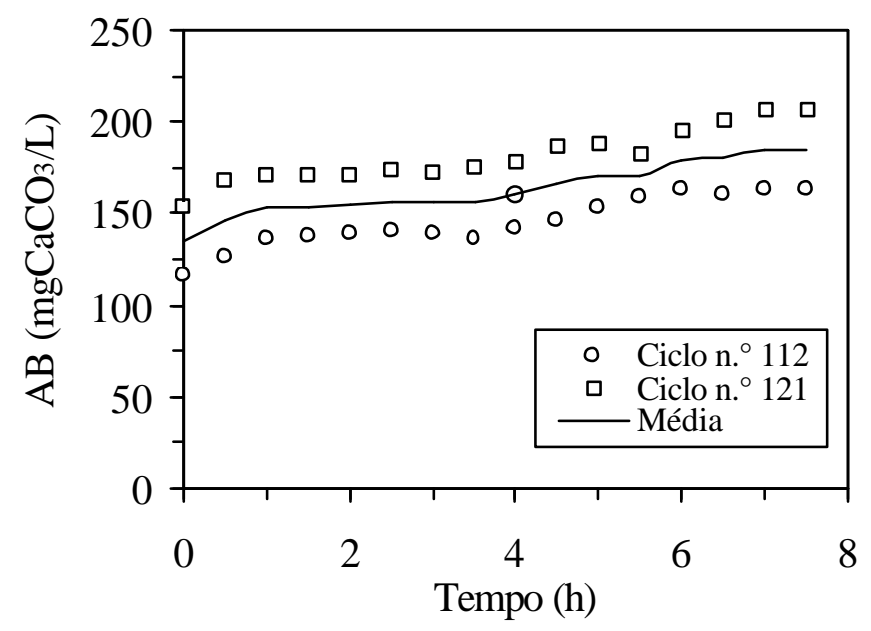

FIGURA 5.17: Perfis de alcalinidade a bicarbonato ao longo da batelada alimentada (2 h) seguida de batelada (6 h). 


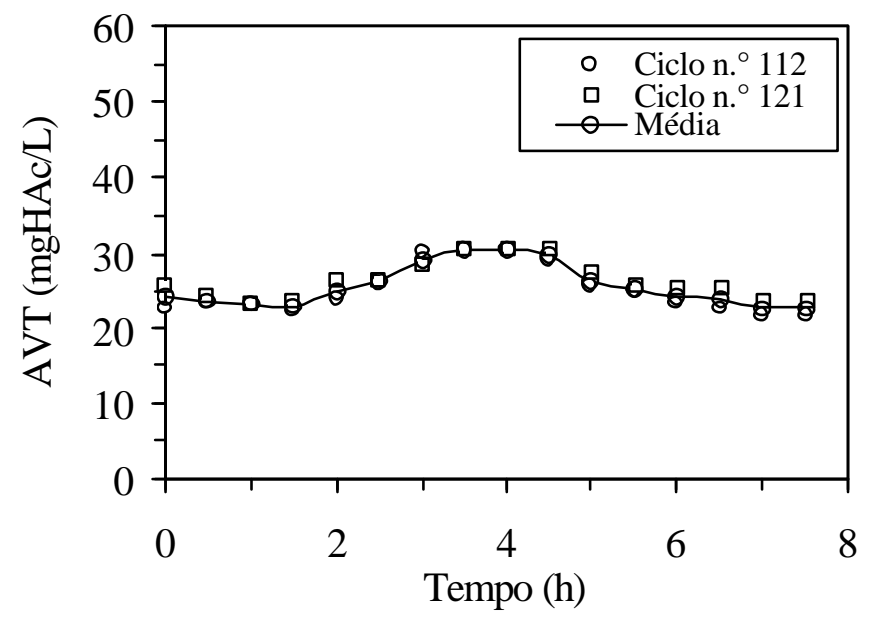

FIGURA 5.18: Perfis de concentração de ácidos voláteis totais ao longo da batelada alimentada (2 h) seguida de batelada (6 h).

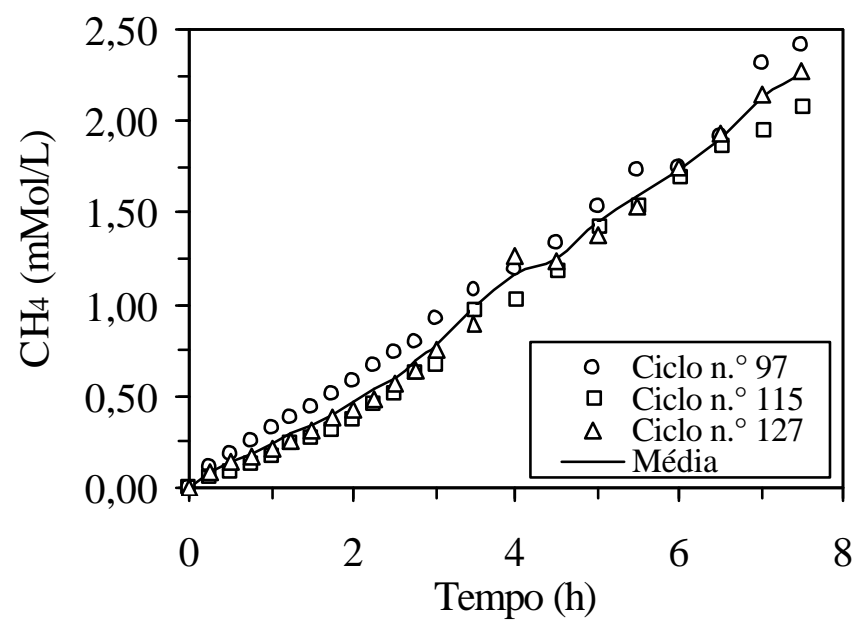

FIGURA 5.19: Perfis de concentração de metano ao longo da batelada alimentada (2 h) seguida de batelada (6 h). 


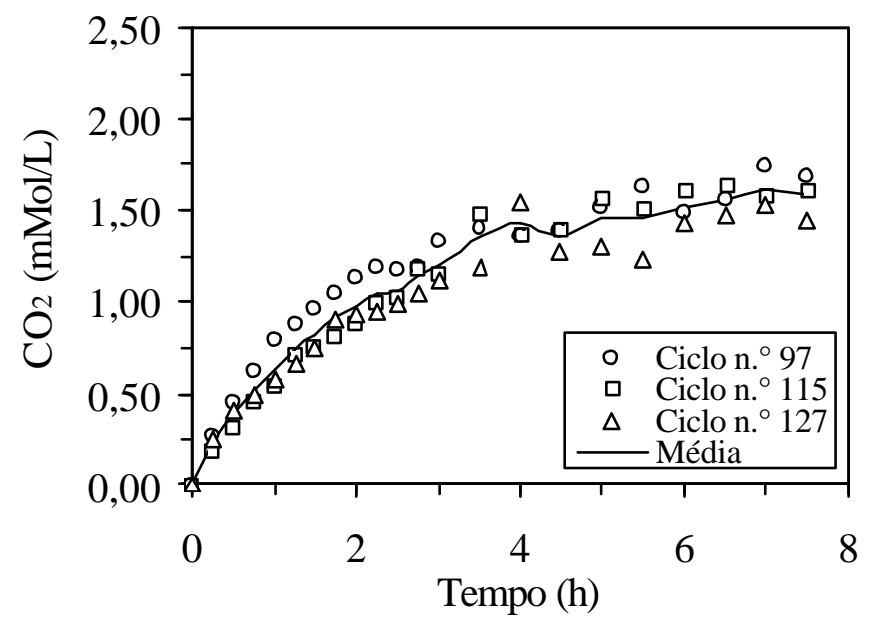

FIGURA 5.20: Perfis de concentração de dióxido de carbono ao longo da batelada alimentada (2 h) seguida de batelada (6 h).

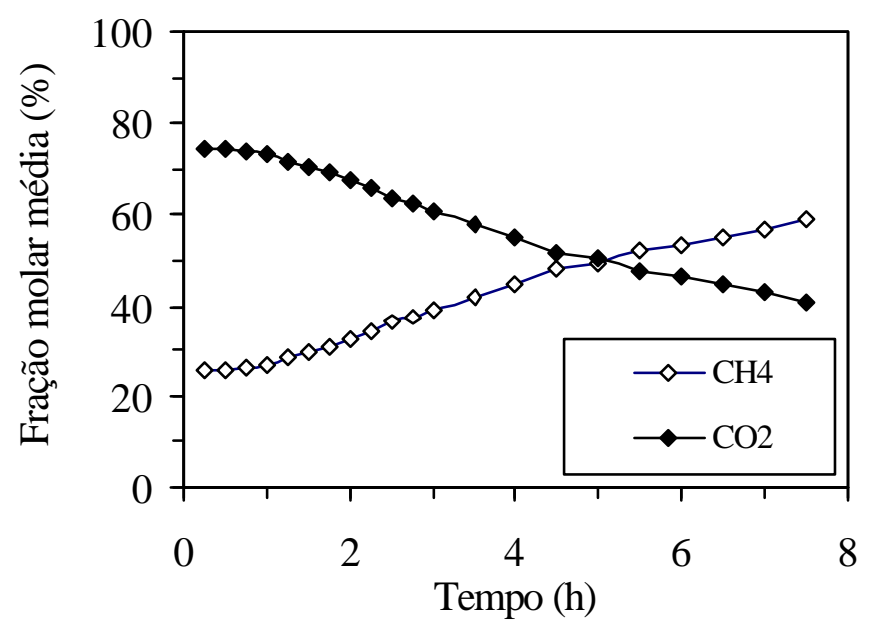

FIGURA 5.21: Fração molar média, em porcentagem, de $\mathrm{CH}_{4}$ e $\mathrm{CO}_{2}$ ao longo da batelada alimentada (2 h) seguida de batelada (6 h).

A análise dos gráficos ilustrados nas Figuras 5.19, 5.20 e 5.21 indica que a digestão anaeróbia da matéria orgânica ocorreu de forma completa para a condição proposta, ou seja, a produção de metano monitorada sugeriu que o consórcio 
microbiano responsável pela conversão encontrava-se em equilíbrio. Ressalta-se que todos os dados referentes aos perfis obtidos estão contidos no Apêndice IV.

\subsubsection{Operação do reator em batelada alimentada $\left(\begin{array}{llll}4 & \text { h }\end{array}\right)$ seguida de batelada (4 h)}

Durante esse ensaio, realizado durante 36 das, submeteu-se o sistema à seguinte estratégia de alimentação: batelada alimentada durante metade do tempo de reação (4 horas), seguida de batelada. Dessa maneira, a razão $t_{\mathrm{F}} / t_{\mathrm{C}}$ equivale a 0,5 . Os seguintes resultados foram alcançados: eficiência média de remoção de $78 \%$ e $72 \%$, para amostras filtradas e não filtradas respectivamente. Considerando-se as cinco semanas de operação, têm-se valores estáveis para o desempenho do sistema, sendo que variações nas concentrações de amostras não filtradas do efluente foram observadas com o decorrer do tempo, devido à presença de material polimérico viscoso no reator. Com o acúmulo de polímeros extracelulares fez-se necessária uma limpeza do sistema para que a obtenção dos perfis dinâmicos fosse efetuada. Os valores médios para esse ensaio são visualizados na Tabela 5.5. A Tabela 5.6 apresenta os dados de concentração dos sólidos relativos à biomassa imobilizada contida no reator (massa de sólidos em questão por unidade de massa do suporte inerte, e massa de sólidos por volume alimentado). 
TABELA 5.5: Valores médios das variáveis monitoradas no ensaio em batelada alimentada (4 h) seguida de batelada (4 h).

\begin{tabular}{|c|c|c|}
\hline Variável & Afluente $^{(a)}$ & Efluente $^{(a)}$ \\
\hline $\mathrm{C}_{\mathrm{ST}}(\mathrm{mgDQO} / \mathrm{L})$ & $520 \pm 58^{(30)}$ & $144 \pm 21^{(25)}$ \\
\hline $\mathrm{C}_{\mathrm{SF}}(\mathrm{mgDQO} / \mathrm{L})$ & - & $114 \pm 17^{(25)}$ \\
\hline$\varepsilon_{S T}(\%)$ & - & $72 \pm 4^{(25)}$ \\
\hline$\varepsilon_{\mathrm{SF}}(\%)$ & - & $78 \pm 4^{(25)}$ \\
\hline AVT (mgHAc/L) & $30 \pm 3^{(7)}$ & $20 \pm 5^{(7)}$ \\
\hline $\mathrm{AB}\left(\mathrm{mgCaCO}_{3} / \mathrm{L}\right)$ & $127 \pm 5^{(7)}$ & $193 \pm 12^{(7)}$ \\
\hline AI/AP & $0,26 \pm 0,03^{(7)}$ & $0,23 \pm 0,04^{(7)}$ \\
\hline $\mathrm{pH}$ & $8,8 \pm 0,3^{(7)}$ & $7,2 \pm 0,2^{(7)}$ \\
\hline Volume (L) & - & $2,49 \pm 0,04$ \\
\hline $\mathrm{ST}(\mathrm{mg} / \mathrm{L})$ & $900 \pm 60^{(7)}$ & $616 \pm 34^{(7)}$ \\
\hline $\mathrm{SVT}(\mathrm{mg} / \mathrm{L})$ & $485 \pm 55^{(7)}$ & $215 \pm 55^{(7)}$ \\
\hline $\mathrm{SST}(\mathrm{mg} / \mathrm{L})$ & $58 \pm 29^{(7)}$ & $53 \pm 22^{(7)}$ \\
\hline $\mathrm{SSV}(\mathrm{mg} / \mathrm{L})$ & $49 \pm 32^{(7)}$ & $38 \pm 21^{(7)}$ \\
\hline
\end{tabular}


TABELA 5.6: Valores dos sólidos da biomassa imobilizada (inóculo) contida no reator operado em batelada alimentada $(4 \mathrm{~h})$ seguida de batelada $(4 \mathrm{~h})$.

\begin{tabular}{|c|c|}
\hline Parâmetro & Inóculo \\
\hline $\mathrm{ST}(\mathrm{mg} / \mathrm{g})^{(a)}$ & 960 \\
\hline $\mathrm{SVT}(\mathrm{mg} / \mathrm{g})^{(a)}$ & 707 \\
\hline $\mathrm{ST}(\mathrm{g} / \mathrm{L})^{(b)}$ & 7,4 \\
\hline $\operatorname{SVT}(\mathrm{g} / \mathrm{L})^{(b)}$ & 5,5 \\
\hline SVT/ST & 0,74 \\
\hline
\end{tabular}

Os valores da concentração de biomassa, representados como concentração de sólidos totais e sólidos voláteis totais dentro do reator, foram obtidos a partir da quantidade média de biomassa por espuma: sabendo-se a quantidade de espuma no reator, determina-se a concentração de biomassa por volume útil do reator.

As Figuras 5.22 e 5.23 mostram respectivamente os valores de concentrações de matéria orgânica das amostras de efluente e as eficiências de remoção obtidas no período, enquanto as Figuras 5.24 e 5.25 ilustram as concentrações de alcalinidade a bicarbonato e ácidos voláteis totais monitoradas durante o ensaio. Os dados de operação obtidos estão contidos no Apêndice II para o afluente e no Apêndice III para o efluente do reator. 


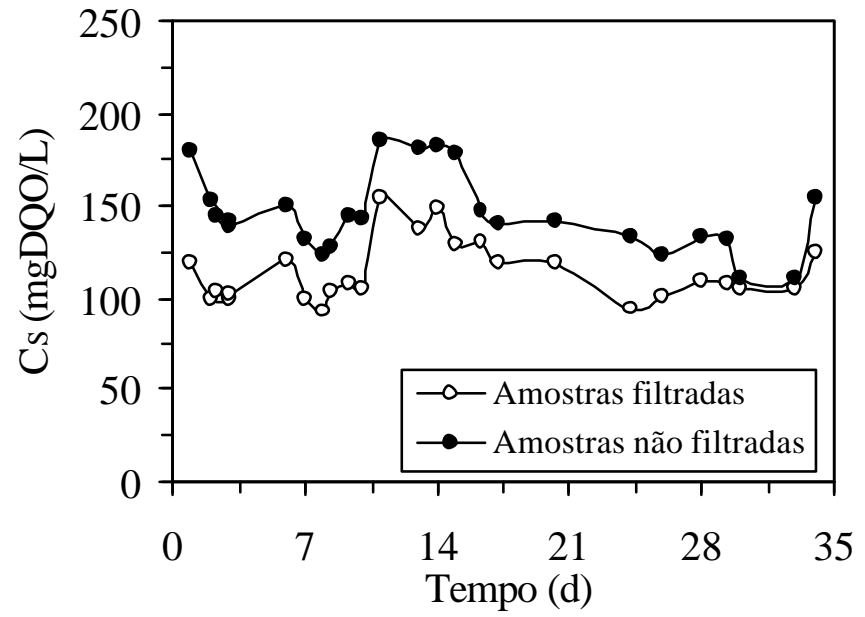

FIGURA 5.22: Concentração de matéria orgânica, em termos de DQO, para a operação em batelada alimentada (4 h) seguida de batelada (4 h).

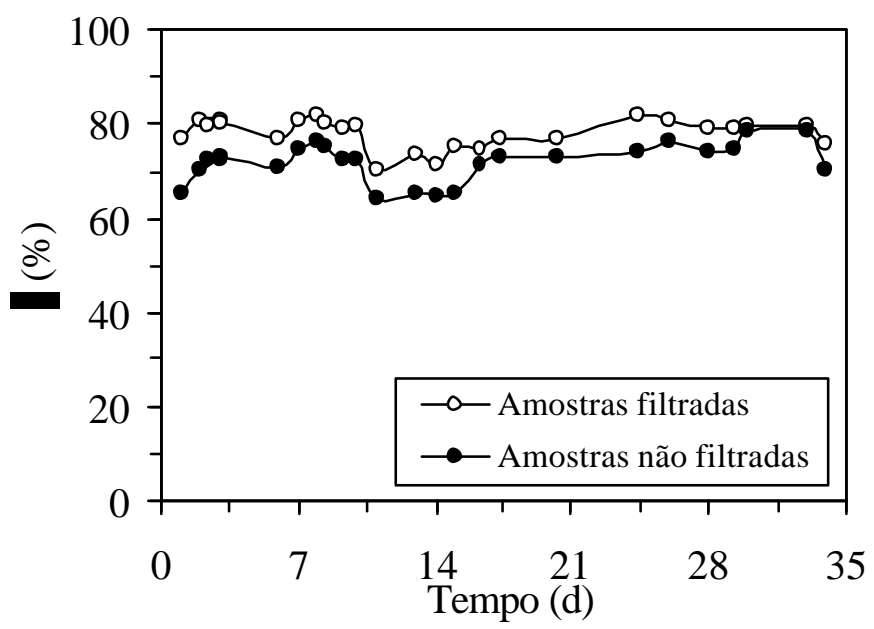

FIGURA 5.23: Eficiência de remoção de matéria orgânica obtida no ensaio em batelada alimentada (4 h) seguida de batelada (4 h). 


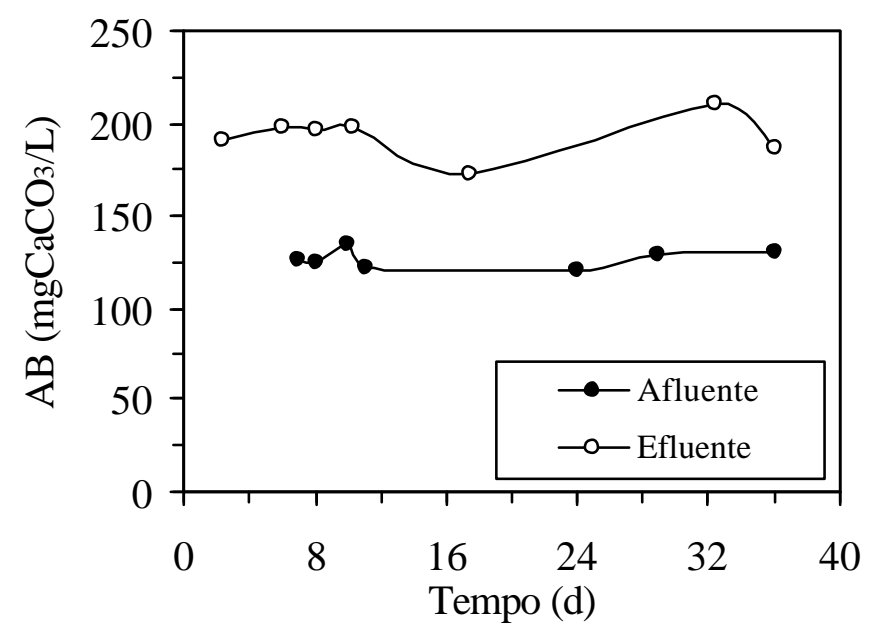

FIGURA 5.24: Alcalinidade a bicarbonato durante o ensaio em batelada alimentada (4 h) seguida de batelada (4 h).

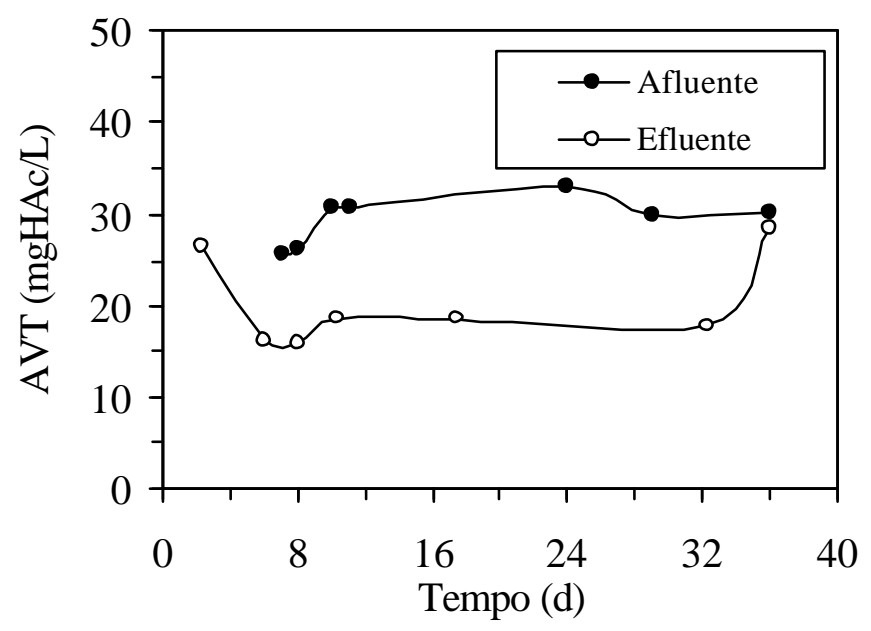

FIGURA 5.25: Concentração de ácidos voláteis totais durante o ensaio em batelada alimentada (4 h) seguida de batelada (4 h).

Os valores de $\mathrm{pH}$ registrados (intervalos de 7,0 a 7,6 no efluente), podem ser citados como indicativo de estabilidade. Constatou-se durante o ensaio tanto a geração de alcalinidade a bicarbonato (média de $127 \mathrm{mgCaCO}_{3} / \mathrm{L}$ no afluente 
e $193 \mathrm{mgCaCO}_{3} / \mathrm{L}$ no efluente), como o não acúmulo de ácidos voláteis totais (médias de $30 \mathrm{mgHAc} / \mathrm{L}$ no afluente e $20 \mathrm{mgHAc} / \mathrm{L}$ no efluente).

Os perfis dinâmicos relativos ao ensaio foram obtidos para as variáveis concentração de substrato (Figura 5.26), alcalinidade a bicarbonato (Figura 5.27), ácidos voláteis totais (5.28) e concentração de biogás (Figuras 5.29, 5.30 e 5.31). Ressalta-se que todos os dados referentes aos perfis obtidos estão contidos no Apêndice IV.

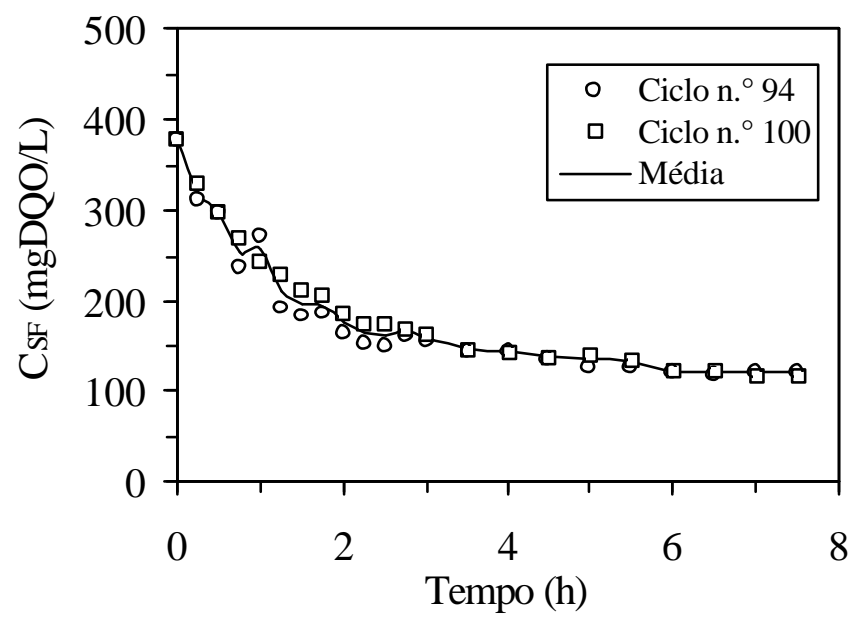

FIGURA 5.26: Perfis de concentração de matéria orgânica ao longo da batelada alimentada (4 h) seguida de batelada (4 h). 


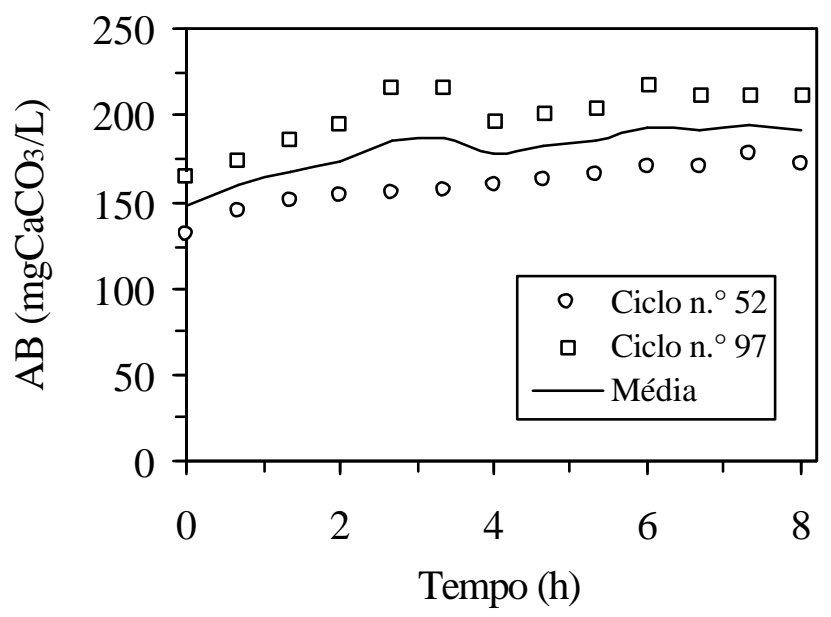

FIGURA 5.27: Perfis de alcalinidade a bicarbonato ao longo da batelada alimentada (4 h) seguida de batelada (4 h).

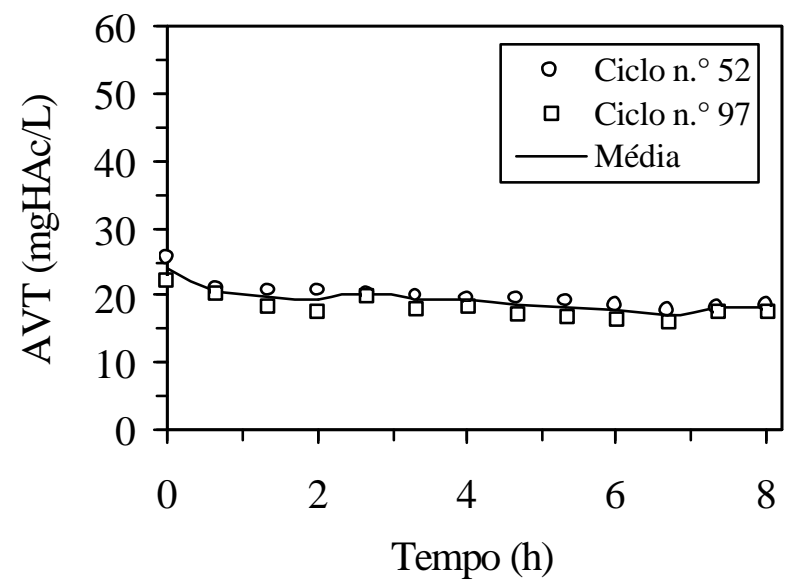

FIGURA 5.28: Perfis de concentração de ácidos voláteis totais ao longo da batelada alimentada (4 h) seguida de batelada (4 h) 


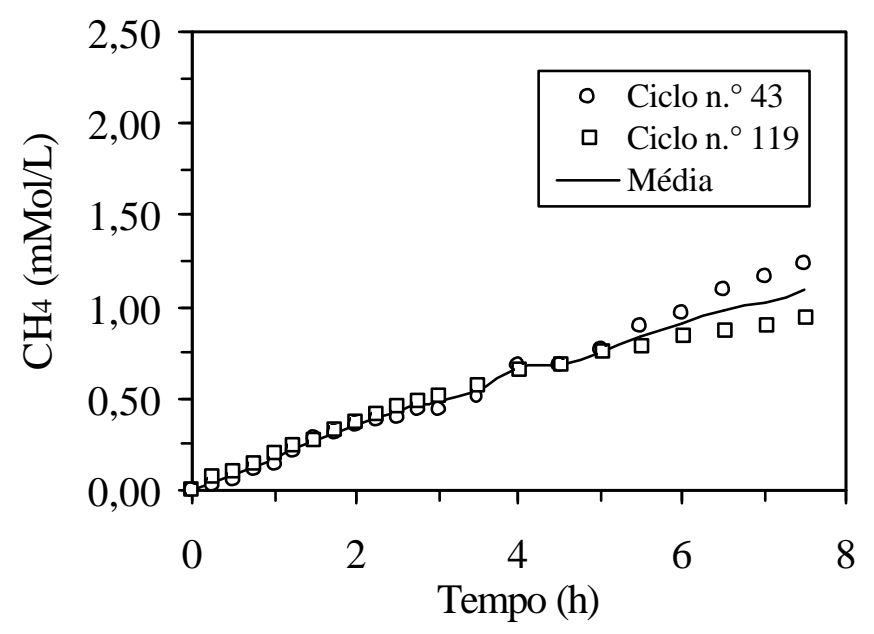

FIGURA 5.29: Perfis de concentração de metano ao longo da batelada alimentada (4 h) seguida de batelada (4 h).

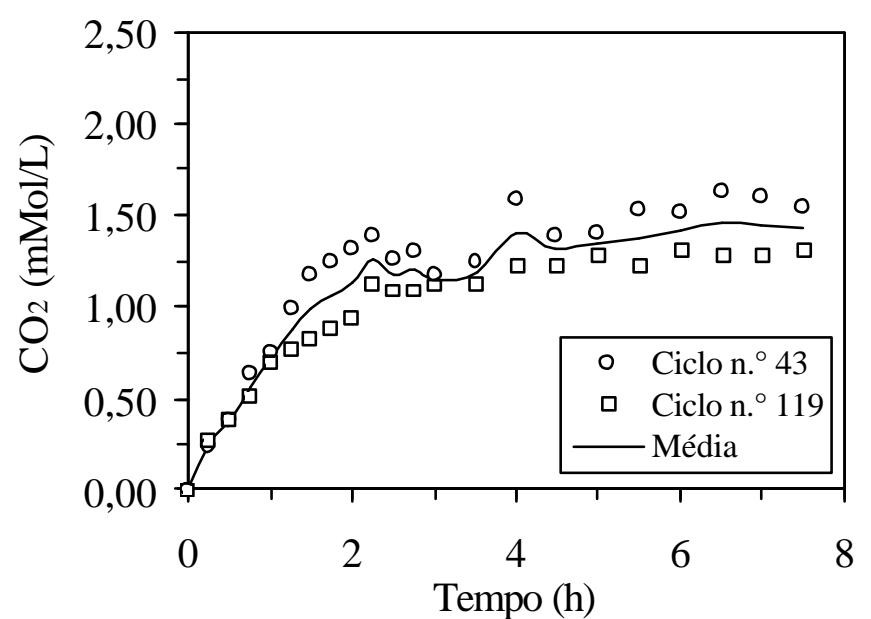

FIGURA 5.30: Perfis de concentração de dióxido de carbono ao longo da batelada alimentada (4 h) seguida de batelada (4 h). 


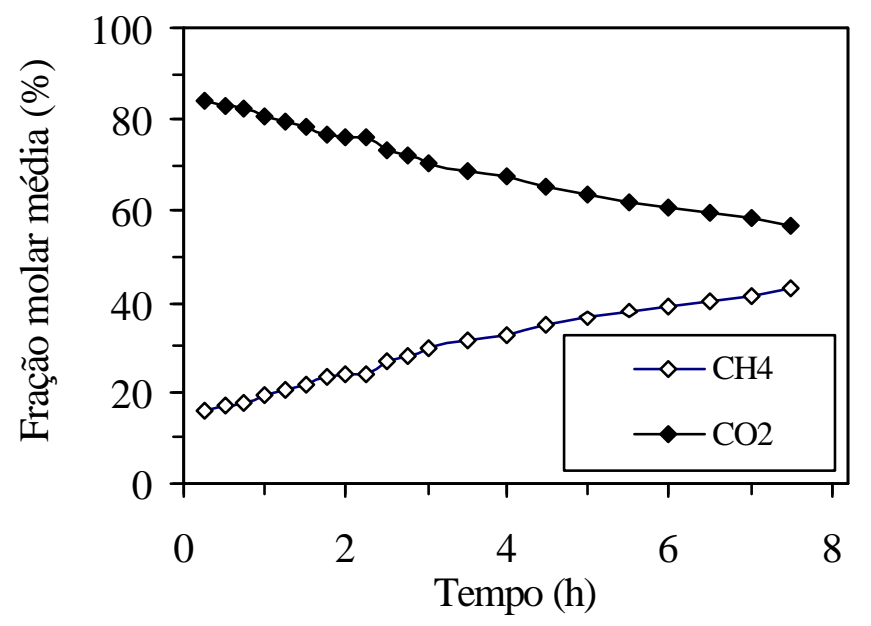

FIGURA 5.31: Fração molar média, em porcentagem, de $\mathrm{CH}_{4}$ e $\mathrm{CO}_{2}$ ao longo da batelada alimentada (4 h) seguida de batelada (4 h).

Através da análise dos gráficos referentes aos perfis obtidos, percebe-se que a formação de ácidos voláteis intermediários é mantida em níveis controlados para a condição proposta. Os valores máximos atingidos na batelada alimentada $(4 \mathrm{~h})$ seguida de batelada $(4 \mathrm{~h})$ foram concentrações de $24 \mathrm{mgHAc} / \mathrm{L}$ enquanto que a operação em batelada, primeira condição estudada, apresentou variações de concentração de ácidos voláteis de 23 a 47 mgHAc/L durante a batelada.

Em relação aos perfis de concentração de matéria orgânica e de biogás, registra-se a degradação da matéria orgânica e a produção de metano durante o ciclo, de acordo com os princípios da digestão anaeróbia. 


\subsubsection{Operação do reator em batelada alimentada $\left(\begin{array}{ll}6 & h\end{array}\right)$ seguida de batelada (2 h)}

Nesta etapa do trabalho submeteu-se o sistema à seguinte estratégia de alimentação: batelada alimentada durante 6 horas, seguida de batelada durante 2 horas, portanto $t_{F} / t_{C}$ equivalente a 0,75 . A operação do sistema estendeu-se por 41 dias. Com o acúmulo de material polimérico entre os cubos de espuma de poliuretano fez-se necessária a limpeza do reator no $27 .^{\circ}$ dia de operação. Na semana anterior a limpeza, os valores médios de concentração de matéria orgânica se encontravam no patamar de $140 \mathrm{mgDQO} / \mathrm{L}$ para amostras filtradas e $179 \mathrm{mgDQO} / \mathrm{L}$ para amostras não filtradas. A limpeza do sistema não causou melhora no desempenho de sistema. Apesar das concentrações de AVT não ultrapassarem o patamar de 26 mgHAc/L com pH efluente sempre superior a 7,2; as concentrações médias para a condição proposta foram de $134 \mathrm{mgDQO} / \mathrm{L}$ e $175 \mathrm{mgDQO} / \mathrm{L}$ para amostras filtradas e não filtradas,equivalendo a eficiências de $74 \%$ e $66 \%$, respectivamente. A Figura 5.32 mostra uma fotografia do cesto de aço inoxidável na ocasião da limpeza. A Tabela 5.7 apresenta os dados de concentração dos sólidos relativos à biomassa imobilizada contida no reator (massa de sólidos em questão por unidade de massa do suporte inerte, e massa de sólidos por volume alimentado) e os valores médios para esse ensaio são visualizados na Tabela 5.8. 


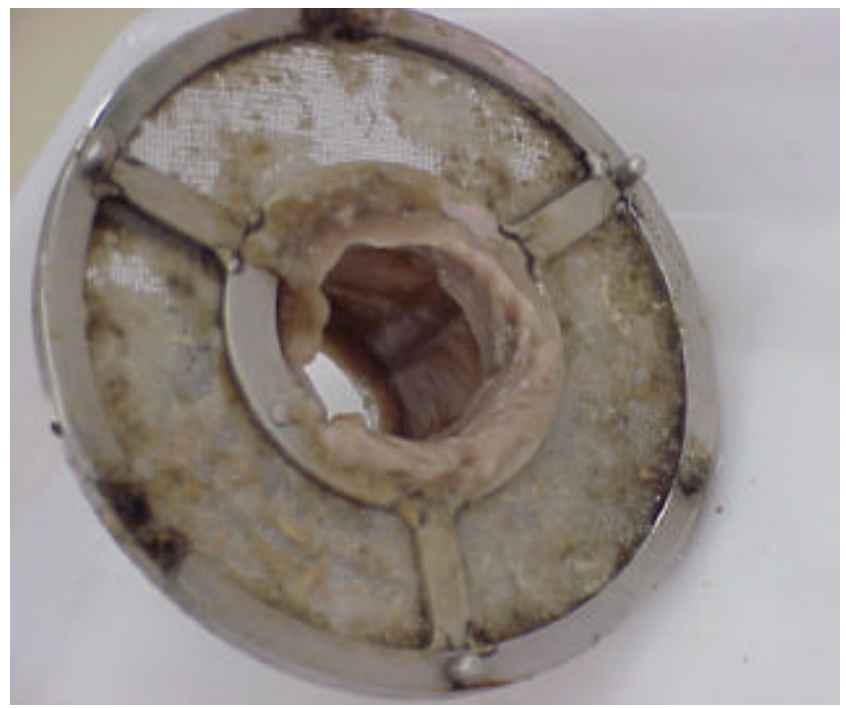

FIGURA 5.32: Fotografia do material polimérico viscoso presente no cilindro onde foi alocado o eixo de agitação, ao final do ensaio em batelada alimentada (6 h) seguida de batelada ( $2 \mathrm{~h})$.

TABELA 5.7: Valores dos sólidos da biomassa imobilizada (inóculo) contida no reator operado em batelada alimentada $(6 \mathrm{~h})$ seguida de batelada $(2 \mathrm{~h})$.

\begin{tabular}{|c|c|}
\hline Parâmetro & Inóculo \\
\hline$\overline{\mathrm{ST}}(\mathrm{mg} / \mathrm{g})^{(a)}$ & 973 \\
\hline $\operatorname{SVT}(\mathrm{mg} / \mathrm{g})^{(a)}$ & 850 \\
\hline $\mathrm{ST}(\mathrm{g} / \mathrm{L})^{(b)}$ & 6,0 \\
\hline $\operatorname{SVT}(\mathrm{g} / \mathrm{L})^{(b)}$ & 5,2 \\
\hline SVT/ST & 0,87 \\
\hline
\end{tabular}


TABELA 5.8: Valores médios das variáveis monitoradas no ensaio em batelada alimentada (6 h) seguida de batelada (2 h).

\begin{tabular}{|c|c|c|}
\hline Variável & Afluente $^{(a)}$ & Efluente $^{(a)}$ \\
\hline$\overline{\mathrm{C}_{\mathrm{ST}}(\mathrm{mgDQO} / \mathrm{L})}$ & $509 \pm 45^{(34)}$ & $175 \pm 45^{(22)}$ \\
\hline $\mathrm{C}_{\mathrm{SF}}(\mathrm{mgDQO} / \mathrm{L})$ & - & $134 \pm 30^{(22)}$ \\
\hline$\varepsilon_{S T}(\%)$ & - & $66 \pm 8^{(22)}$ \\
\hline$\varepsilon_{\mathrm{SF}}(\%)$ & - & $74 \pm 6^{(22)}$ \\
\hline AVT (mgHAc/L) & $30 \pm 2^{(9)}$ & $23 \pm 2^{(10)}$ \\
\hline $\mathrm{AB}\left(\mathrm{mgCaCO}_{3} / \mathrm{L}\right)$ & $128 \pm 11^{(9)}$ & $198 \pm 11^{(10)}$ \\
\hline AI/AP & $0,23 \pm 0,04^{(9)}$ & $0,21 \pm 0,03^{(10)}$ \\
\hline $\mathrm{pH}$ & $8,4 \pm 0,7^{(9)}$ & $7,5 \pm 0,2^{(10)}$ \\
\hline Volume (L) & - & $2,49 \pm 0,04^{(21)}$ \\
\hline $\mathrm{ST}(\mathrm{mg} / \mathrm{L})$ & $987 \pm 109^{(8)}$ & $688 \pm 55^{(8)}$ \\
\hline $\mathrm{SVT}(\mathrm{mg} / \mathrm{L})$ & $516 \pm 58^{(8)}$ & $240 \pm 73^{(8)}$ \\
\hline $\mathrm{SST}(\mathrm{mg} / \mathrm{L})$ & $70 \pm 29^{(8)}$ & $53 \pm 23^{(8)}$ \\
\hline $\mathrm{SSV}(\mathrm{mg} / \mathrm{L})$ & $47 \pm 22^{(8)}$ & $32 \pm 15^{(8)}$ \\
\hline
\end{tabular}

As Figuras 5.33 a 5.36 mostram respectivamente os valores de concentrações de matéria orgânica das amostras de efluente, eficiência de remoção obtida no período, alcalinidade a bicarbonato e concentrações de ácidos voláteis totais monitoradas durante o ensaio. Os dados de operação obtidos estão contidos no Apêndice II para o afluente e no Apêndice III para o efluente do reator. 


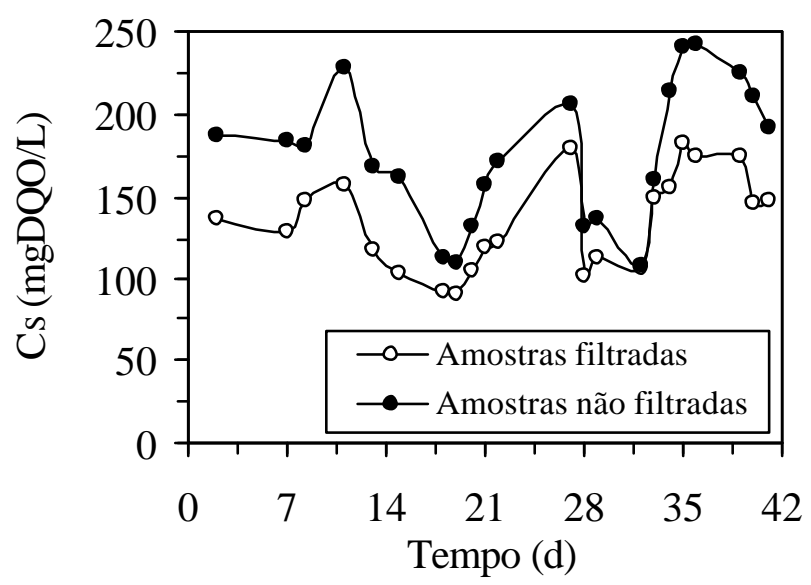

FIGURA 5.33: Concentração de matéria orgânica, em termos de DQO, para a operação em batelada alimentada (6 h) seguida de batelada $(2 \mathrm{~h})$.

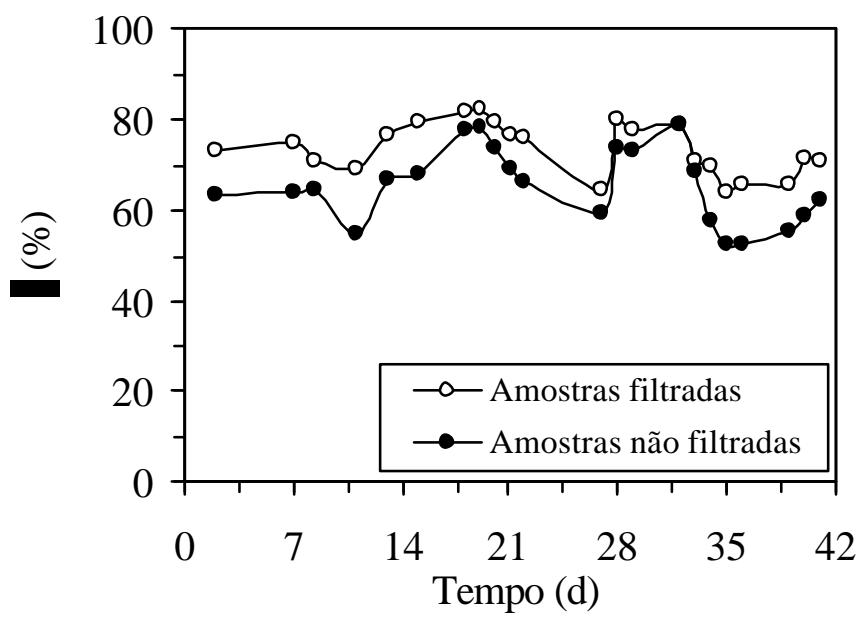

FIGURA 5.34: Eficiência de remoção de matéria orgânica obtida no ensaio em batelada alimentada (6 h) seguida de batelada (2 h). 


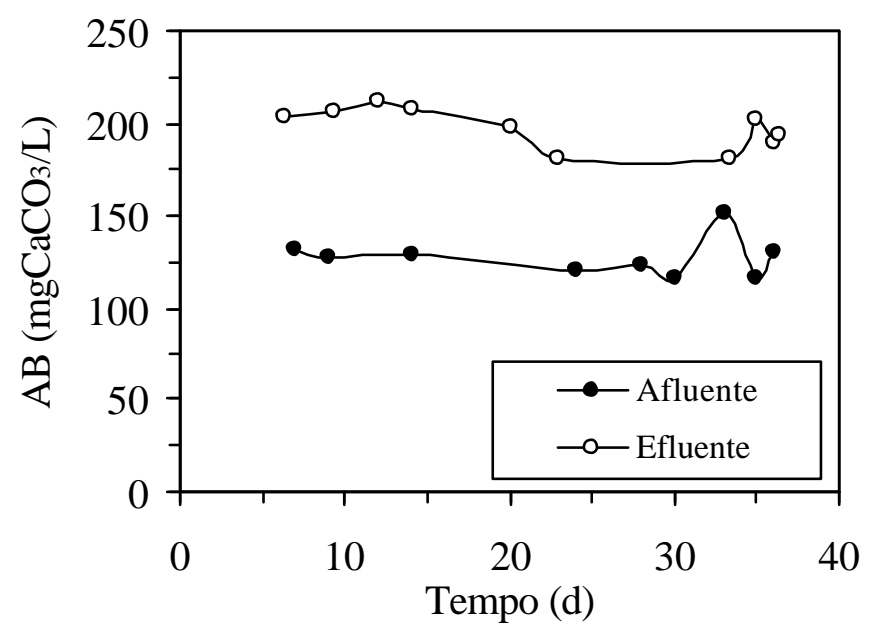

FIGURA 5.35: Alcalinidade a bicarbonato durante o ensaio em batelada alimentada (6 h) seguida de batelada (2 h).

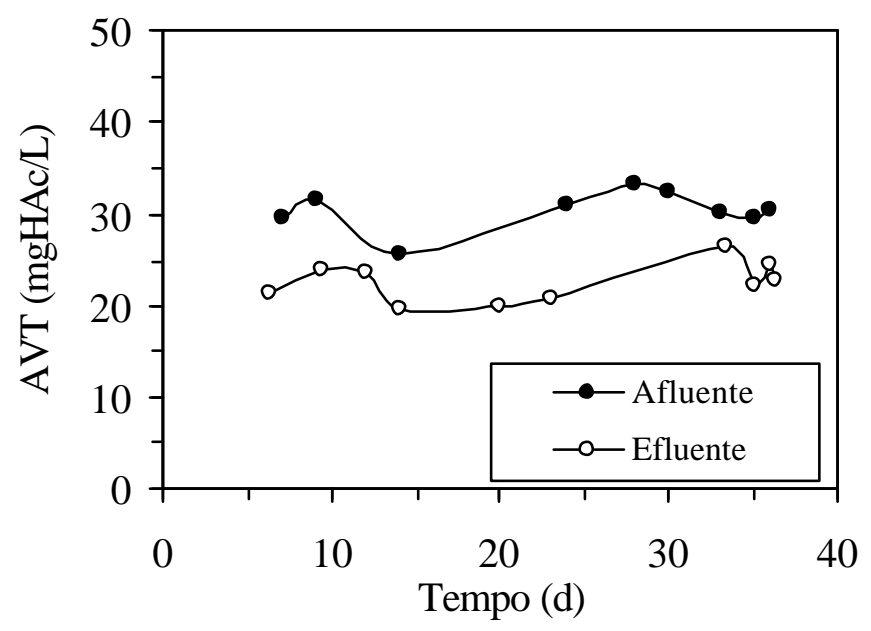

FIGURA 5.36: Concentração de ácidos voláteis totais durante o ensaio em batelada alimentada (6 h) seguida de batelada (2 h).

Os perfis dinâmicos relativos ao ensaio foram obtidos no intervalo entre o $29 .^{\circ}$ e o $41 .^{\circ}$ de operação (Figuras 5.37 a 5.42). A análise dos gráficos demonstra a perda de eficiência do sistema. O valor médio de concentração residual de matéria 
orgânica, ao fim do ciclo, foi de $156 \mathrm{mgDQO} / \mathrm{L}$ (Figura 5.37); além disso a concentração de metano não ultrapassou 0,44 mMol/L (Figura 5.40). Na condição anterior $\left(\mathrm{t}_{\mathrm{F}} / \mathrm{t}_{\mathrm{C}}=0,5\right)$ níveis de $1,24 \mathrm{mMol} / \mathrm{L}$ foram atingidos. Todavia, é preciso ressaltar que houve aumento da alcalinidade a bicarbonato (Figura 5.38) e consumo de ácidos voláteis ao longo do ciclo (Figura 5.39). Todos os dados referentes aos perfis estão contidos no Apêndice IV.

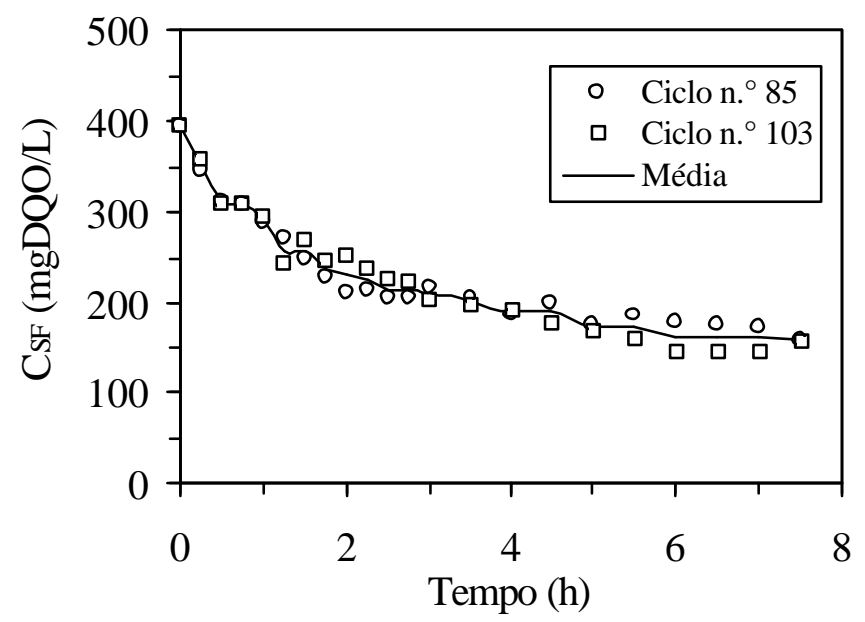

FIGURA 5.37: Perfis de concentração de substrato ao longo da batelada alimentada (6 h) seguida de batelada (2 h). 


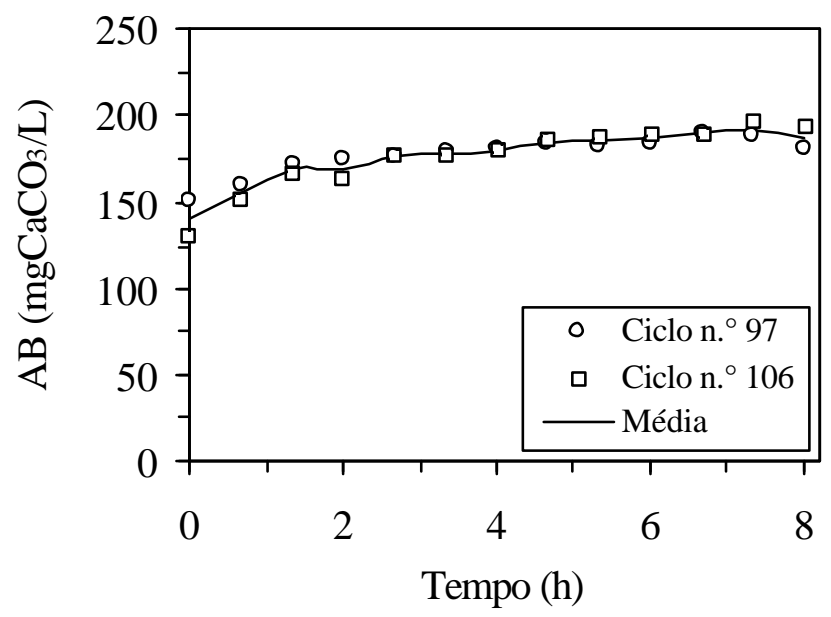

FIGURA 5.38: Perfis de alcalinidade a bicarbonato ao longo da batelada alimentada (6 h) seguida de batelada (2 h).

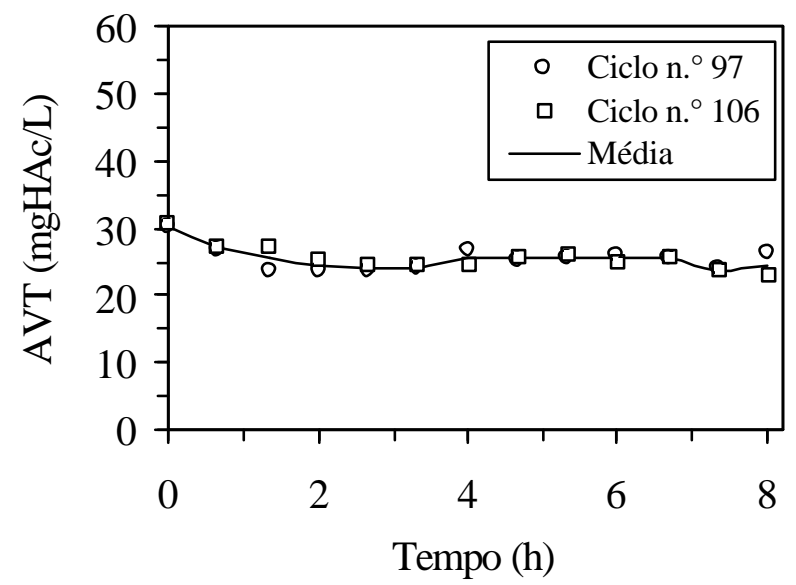

FIGURA 5.39: Perfis de concentração de ácidos voláteis totais ao longo da batelada alimentada (6 h) seguida de batelada (2 h). 


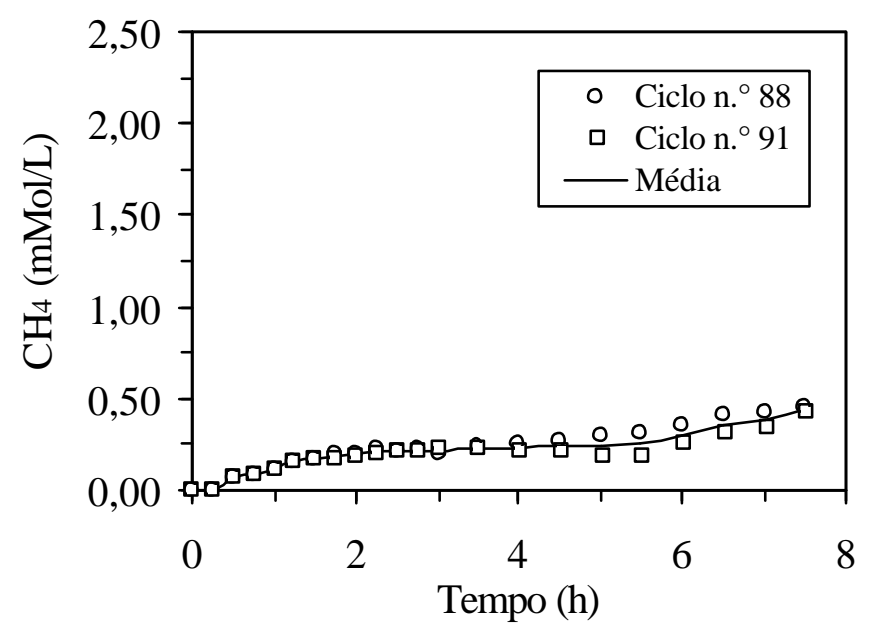

FIGURA 5.40: Perfis de concentração de metano ao longo da batelada alimentada (6 h) seguida de batelada (2 h).

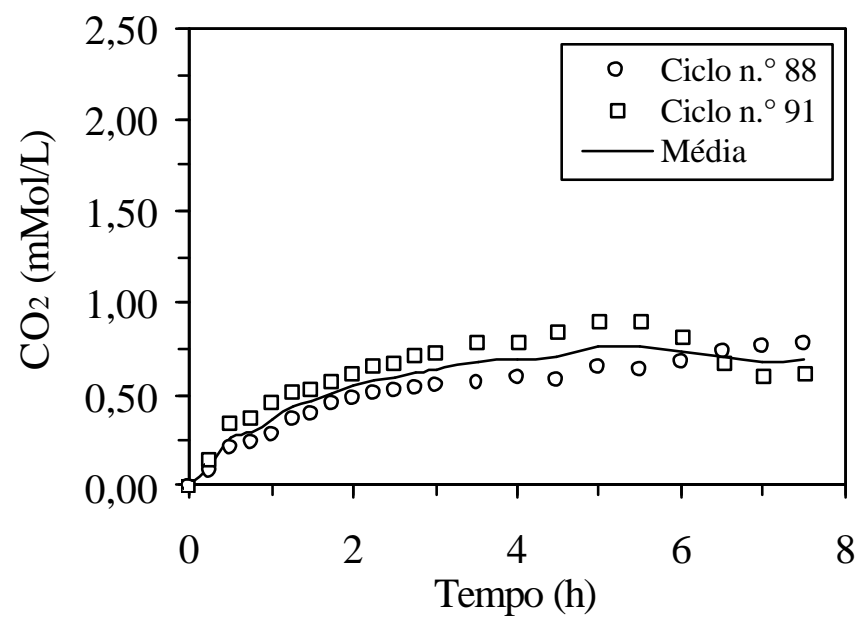

FIGURA 5.41: Perfis de concentração de dióxido de carbono ao longo da batelada alimentada (6 h) seguida de batelada (2 h). 


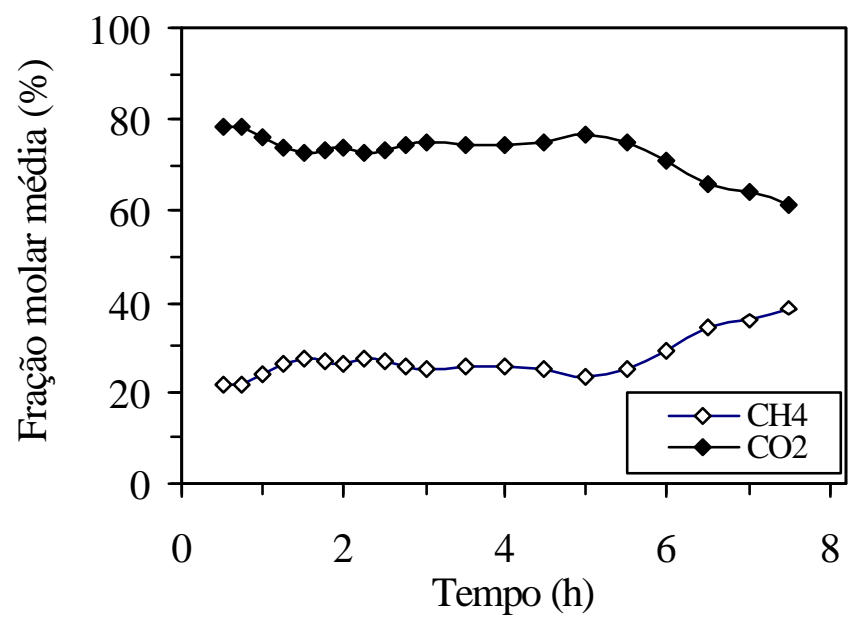

FIGURA 5.42: Fração molar média, em porcentagem, de $\mathrm{CH}_{4}$ e $\mathrm{CO}_{2}$ ao longo da batelada alimentada (6 h) seguida de batelada $(2 \mathrm{~h})$.

\subsubsection{Operação do reator em batelada alimentada $(8$ h)}

Após a finalização do ensaio em batelada alimentada $(6 \mathrm{~h})$ seguida de batelada $(2$ h), iniciou-se a operação do reator operado em batelada alimentada. $\mathrm{O}$ reator foi carregado até a cota superior do cesto de aço inoxidável (volume correspondente a 1,5 L) em 10 minutos. Após esse período, uma alimentação adicional de $1 \mathrm{~L}$ foi efetuada, uniformemente durante 460 minutos. Essa estratégia caracterizou a operação do reator em batelada alimentada, durante todo o período de reação. Os 10 minutos restantes do ciclo de 8 horas foram destinados a descarga do sistema. O ensaio foi realizado em 35 dias e os valores médios das variáveis monitoradas estão contidos na Tabela 5.9. A Tabela 5.10 apresenta os dados de concentração dos sólidos relativos à biomassa imobilizada contida no reator (massa de sólidos em questão por unidade de massa do suporte inerte, e massa de sólidos por volume alimentado). 
TABELA 5.9: Valores médios das variáveis monitoradas no ensaio em batelada alimentada (8 h).

\begin{tabular}{|c|c|c|}
\hline Variável & Afluente $^{(a)}$ & Efluente $^{(a)}$ \\
\hline $\mathrm{C}_{\mathrm{ST}}(\mathrm{mgDQO} / \mathrm{L})$ & $535 \pm 44^{(29)}$ & $192 \pm 46^{(20)}$ \\
\hline $\mathrm{C}_{\mathrm{SF}}(\mathrm{mgDQO} / \mathrm{L})$ & - & $154 \pm 21^{(20)}$ \\
\hline$\varepsilon_{S T}(\%)$ & - & $64 \pm 9^{(20)}$ \\
\hline$\varepsilon_{\mathrm{SF}}(\%)$ & - & $71 \pm 4^{(20)}$ \\
\hline AVT (mgHAc/L) & $32 \pm 5^{(10)}$ & $23 \pm 3^{(8)}$ \\
\hline $\mathrm{AB}\left(\mathrm{mgCaCO}_{3} / \mathrm{L}\right)$ & $126 \pm 9^{(10)}$ & $191 \pm 15^{(8)}$ \\
\hline AI/AP & $0,22 \pm 0,04^{(10)}$ & $0,25 \pm 0,05^{(8)}$ \\
\hline $\mathrm{pH}$ & $8,2 \pm 0,7^{(10)}$ & $7,3 \pm 0,1^{(8)}$ \\
\hline Volume (L) & - & $2,50 \pm 0,07^{(16)}$ \\
\hline $\mathrm{ST}(\mathrm{mg} / \mathrm{L})$ & $1002 \pm 61^{(8)}$ & $786 \pm 143^{(8)}$ \\
\hline $\mathrm{SVT}(\mathrm{mg} / \mathrm{L})$ & $518 \pm 60^{(8)}$ & $252 \pm 41^{(8)}$ \\
\hline $\mathrm{SST}(\mathrm{mg} / \mathrm{L})$ & $62 \pm 29^{(8)}$ & $54 \pm 29^{(8)}$ \\
\hline $\mathrm{SSV}(\mathrm{mg} / \mathrm{L})$ & $49 \pm 24^{(8)}$ & $32 \pm 28^{(8)}$ \\
\hline
\end{tabular}


TABELA 5.10: Valores dos sólidos da biomassa imobilizada (inóculo) contida no reator operado em batelada alimentada $(8 \mathrm{~h})$.

\begin{tabular}{cc}
\hline Parâmetro & Inóculo \\
\hline ST $(\mathrm{mg} / \mathrm{g})^{(a)}$ & 782 \\
$\mathrm{SVT}(\mathrm{mg} / \mathrm{g})^{(a)}$ & 608 \\
$\mathrm{ST}(\mathrm{g} / \mathrm{L})^{(b)}$ & 6,0 \\
$\mathrm{SVT}(\mathrm{g} / \mathrm{L})^{(b)}$ & 4,7 \\
$\mathrm{SVT} / \mathrm{ST}$ & 0,78 \\
\\
$\begin{array}{l}\text { (a) }(\mathrm{mg} \text { de sólidos/g de espuma de poliuretano). } \\
\text { (b) }(\mathrm{g} \text { de sólidos/L de volume de água residuária tratada). }\end{array}$
\end{tabular}

As Figuras 5.43 e 5.44 mostram respectivamente os valores de concentrações de matéria orgânica das amostras de efluente e as eficiências de remoção obtidas no período, enquanto as Figuras 5.45 e 5.46 ilustram os valores de alcalinidade a bicarbonato e de concentrações de ácidos voláteis totais monitoradas durante o ensaio. Os dados de operação nessa condição estão contidos no Apêndice II para o afluente e no Apêndice III para o efluente do reator. 


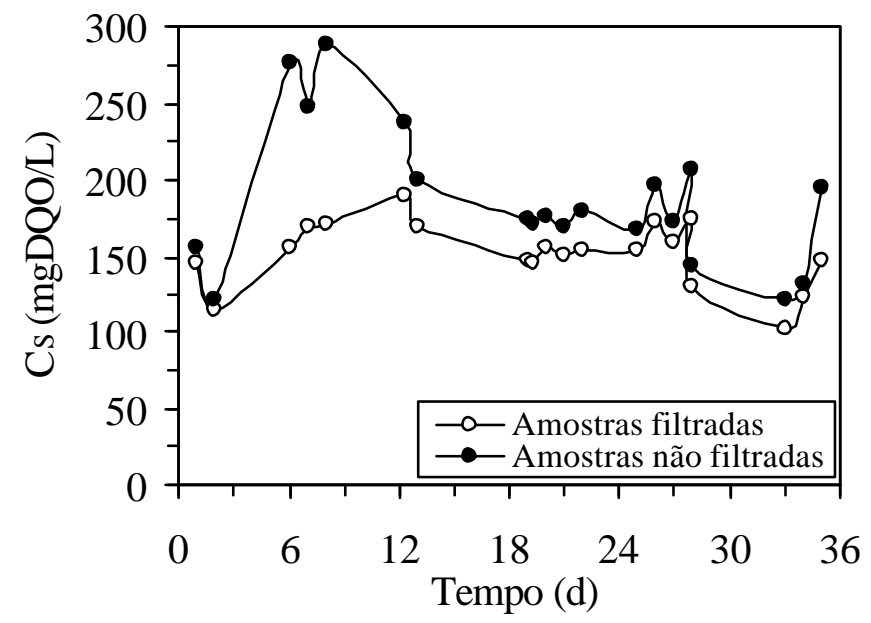

FIGURA 5.43: Concentração de matéria orgânica, em termos de DQO, para a operação em batelada alimentada $(8 \mathrm{~h})$.

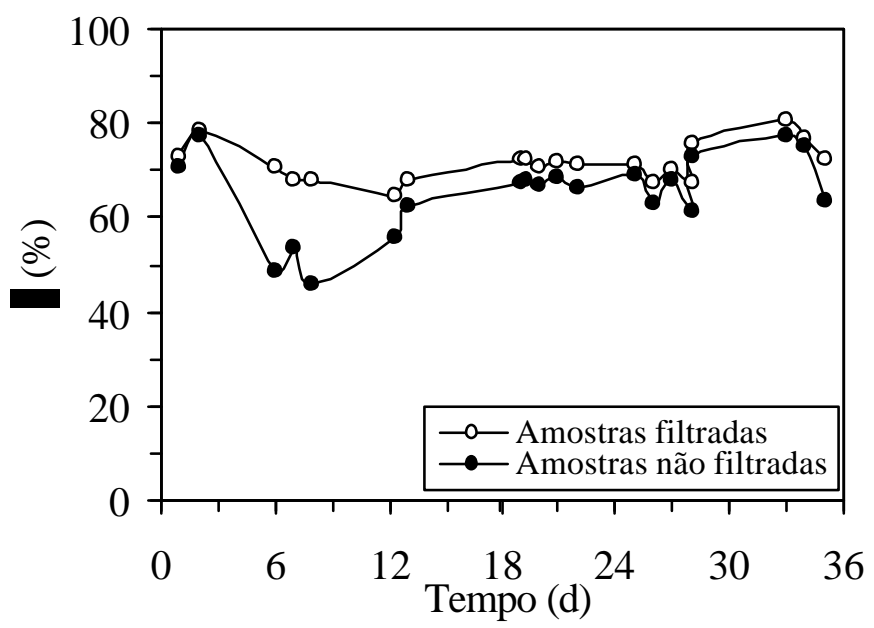

FIGURA 5.44: Eficiência de remoção de matéria orgânica obtida no ensaio em batelada alimentada $(8 \mathrm{~h})$. 


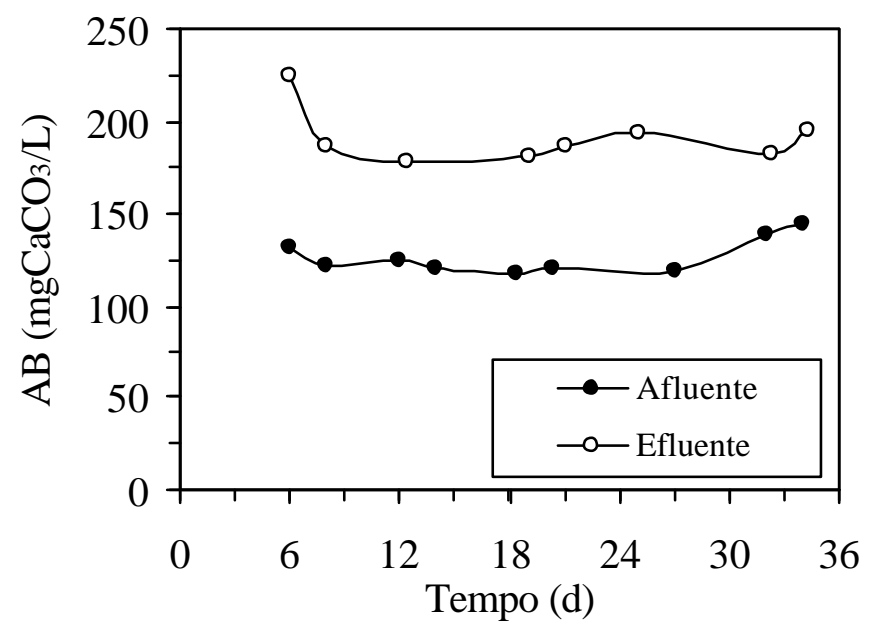

FIGURA 5.45: Alcalinidade a bicarbonato durante o ensaio em batelada alimentada (8 h).

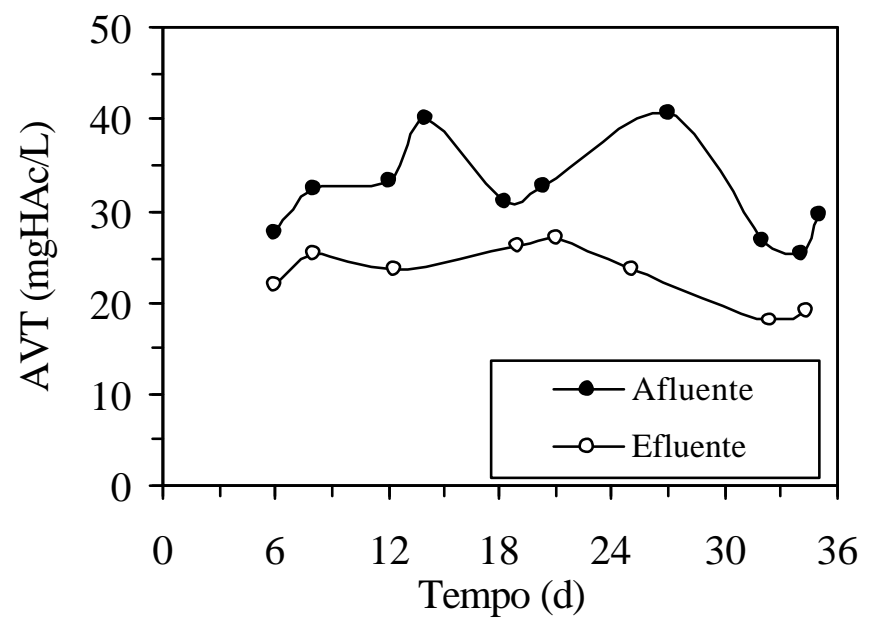

FIGURA 5.46: Concentração de ácidos voláteis totais durante o ensaio em batelada alimentada $(8 \mathrm{~h})$.

Os valores de concentração de ácidos voláteis totais se mantiveram baixos (média de $23 \mathrm{mHAc} / \mathrm{L}$ no efluente) e constatou-se geração de alcalinidade a bicarbonato em todo o período (médias de $126 \mathrm{mgCaCO}_{3} / \mathrm{L}$ no afluente e 
de $191 \mathrm{mgCaCO}_{3} / \mathrm{L}$ no efluente). Entretanto, quanto à eficiência de remoção, notou-se uma queda em relação às porcentagens registradas nas condições anteriores (médias de $71 \%$ e $64 \%$, para amostras filtradas e não filtradas, respectivamente). Os perfis de remoção de matéria orgânica ao longo do tempo de batelada, visualizados na Figura 5.47 foram obtidos em amostragens realizadas no $26 .^{\circ}$ e $33 .^{\circ}$ dias.

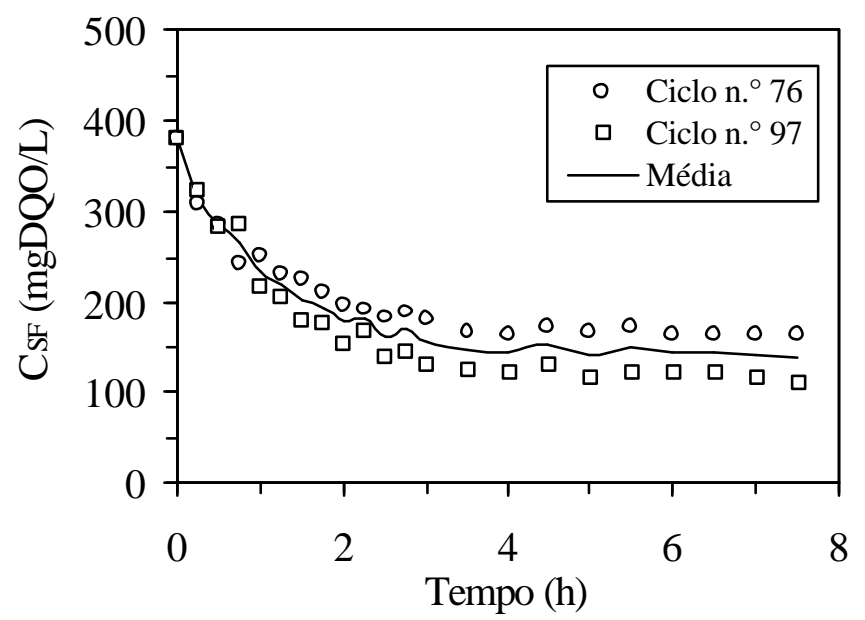

FIGURA 5.47: Perfis de concentração de substrato ao longo da batelada alimentada (8 h).

O comportamento dos perfis de alcalinidade a bicarbonato e concentrações de ácidos voláteis é visualizado nas Figuras 5.48 e 5.49. Observa-se que para a operação em batelada alimentada, há um controle na formação de ácidos voláteis durante o ciclo (valores abaixo de $20 \mathrm{mgHAc} / \mathrm{L}$ a partir de 1,33 h de reação).

Perfis de composição do biogás foram obtidos no $29 .^{\circ}$ e $35 .^{\circ}$ dias. As Figuras 5.50 e 5.51 mostram as concentrações de metano e dióxido de carbono, respectivamente, e a Figura 5.52 ilustra a média das frações molares, para as duas amostragens realizadas, de $\mathrm{CH}_{4}$ e $\mathrm{CO}_{2}$. Os valores percentuais foram calculados 
considerando-se que o biogás era composto apenas pelos gases monitorados. Todos os dados referentes aos perfis obtidos estão contidos no Apêndice IV.

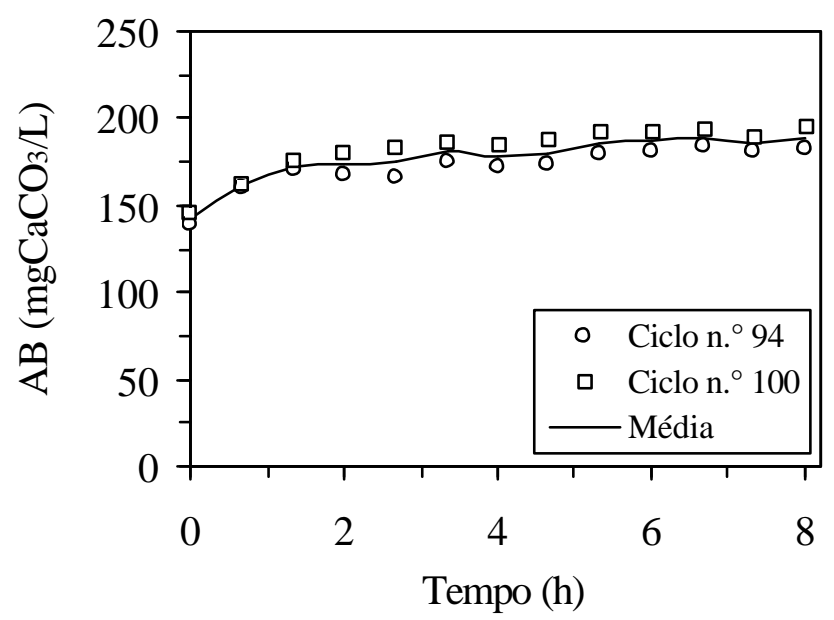

FIGURA 5.48: Perfis de alcalinidade a bicarbonato ao longo da batelada alimentada $(8 \mathrm{~h})$.

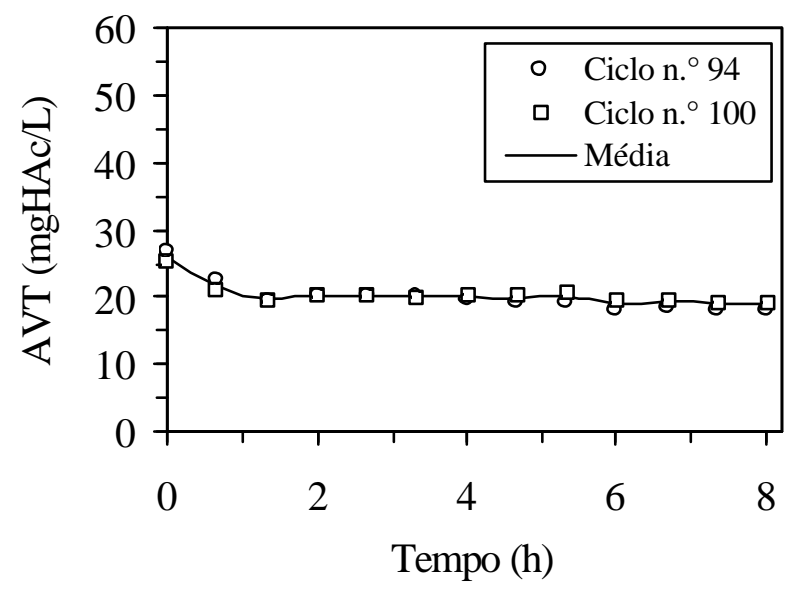

FIGURA 5.49: Perfis de concentração de ácidos voláteis totais ao longo da batelada alimentada $(8 \mathrm{~h})$. 


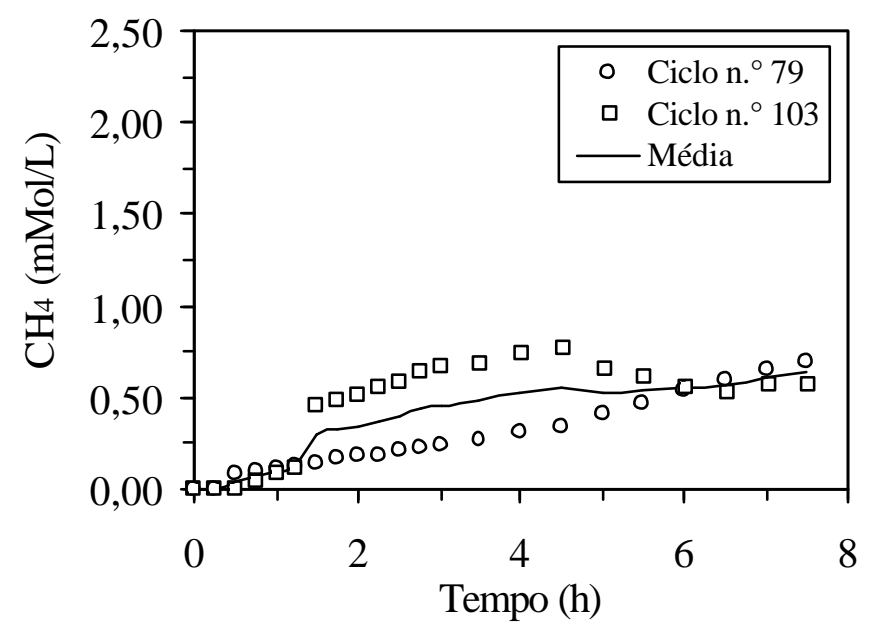

FIGURA 5.50: Perfis de concentração de metano ao longo da batelada alimentada (8 h).

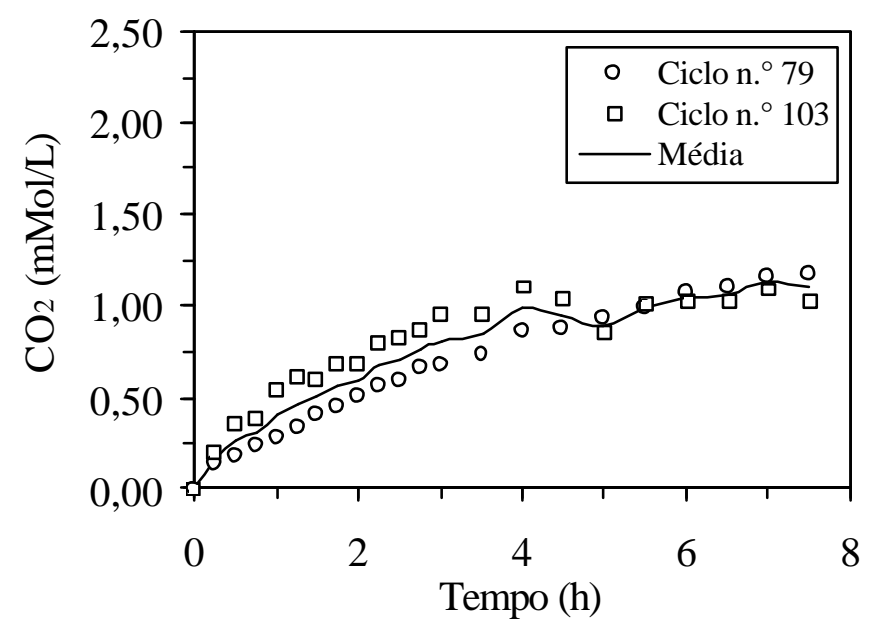

FIGURA 5.51: Perfis de concentração de dióxido de carbono ao longo da batelada alimentada (8 h). 


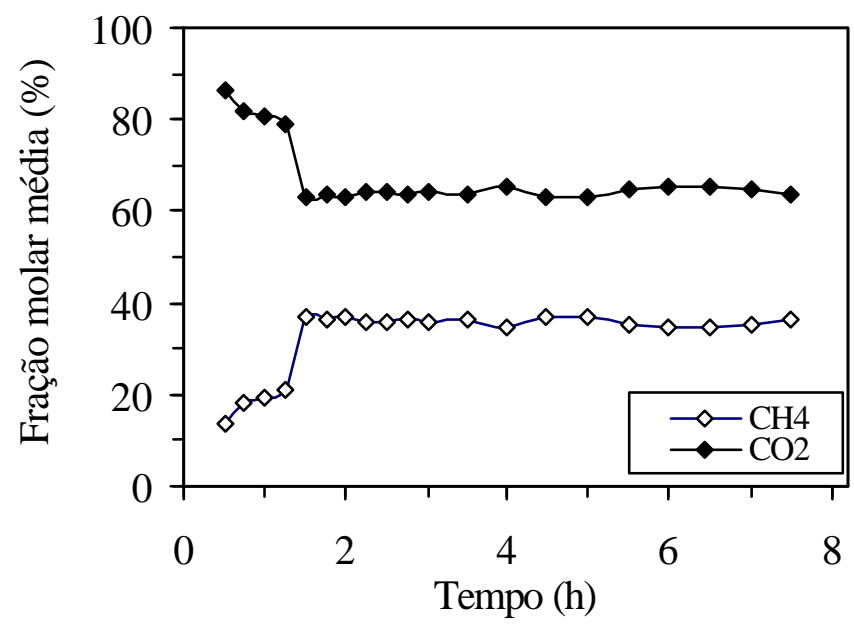

FIGURA 5.52: Fração molar média, em porcentagem, de $\mathrm{CH}_{4}$ e $\mathrm{CO}_{2}$ ao longo da batelada alimentada $(8 \mathrm{~h})$.

\subsection{Comparação da eficiência e estabilidade do sistema, quando submetido a diferentes estratégias de alimentação}

Os dados obtidos permitem que uma análise comparativa do sistema, quando submetido aos ensaios propostos, seja efetuada. A eficiência de remoção de substrato (ع) no reator é visualizada na Figura 5.53. Na elaboração desse gráfico não foi considerado o ensaio preliminar realizado para verificação do sistema e ajustes operacionais. Para o cálculo do desempenho, foi usada a média dos afluentes preparados ao longo das cinco condições experimentais propostas $(509 \mathrm{mgDQO} / \mathrm{L}$ para 188 dias). 


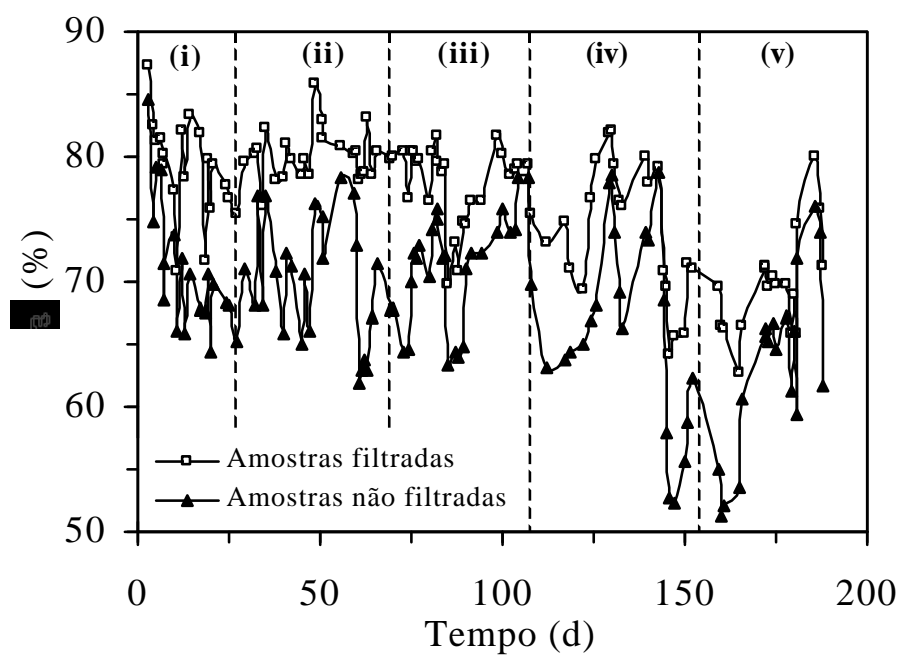

FIGURA 5.53: Eficiência de remoção de substrato $(\varepsilon)$ no reator. (i) batelada,

(ii) batelada alimentada/ batelada: $t_{\mathrm{F}}=120 \mathrm{~min}$, (iii) batelada alimentada/ batelada: $\mathrm{t}_{\mathrm{F}}=240 \mathrm{~min}$, (iv) batelada alimentada/ batelada: $\mathrm{t}_{\mathrm{F}}=360 \mathrm{~min} \mathrm{e}$ (v) batelada alimentada $: t_{F}=460 \mathrm{~min}$.

As Tabelas 5.11 e 5.12 contêm os valores médios obtidos para as cinco estratégias de alimentação pesquisadas. 
TABELA 5.11: Variáveis monitoradas no reator para as diferentes estratégias de alimentação.

\begin{tabular}{|c|c|c|c|c|c|c|}
\hline \multirow{2}{*}{$\mathbf{t}_{\mathbf{F}}^{*}(\min )$} & \multicolumn{3}{|c|}{$\mathrm{C}_{\mathrm{S}}(\mathrm{mgDQO} / \mathrm{L})$} & \multicolumn{2}{|l|}{$\varepsilon(\%)$} & \multirow{2}{*}{$\mathbf{V}_{\mathbf{T}}^{(c)}(\mathbf{L})$} \\
\hline & $\mathrm{C}_{\mathrm{AT}}{ }^{(\mathbf{a})}$ & $\mathrm{C}_{\mathrm{ST}}^{(\mathbf{b})}$ & $\mathbf{C}_{\mathrm{SF}}^{(\mathbf{b})}$ & $\varepsilon_{S T}{ }^{(b)}$ & $\varepsilon_{\mathbf{S F}}^{(b)}$ & \\
\hline 0 & $497 \pm 26$ & $152 \pm 21$ & $109 \pm 18$ & $70 \pm 4$ & $78 \pm 4$ & $2,46 \pm 0,43$ \\
\hline 120 & $533 \pm 43$ & $155 \pm 25$ & $101 \pm 10$ & $71 \pm 5$ & $81 \pm 2$ & $2,50 \pm 0,05$ \\
\hline 240 & $520 \pm 58$ & $144 \pm 22$ & $115 \pm 17$ & $72 \pm 4$ & $78 \pm 3$ & $2,49 \pm 0,04$ \\
\hline 360 & $509 \pm 45$ & $175 \pm 43$ & $134 \pm 30$ & $66 \pm 8$ & $74 \pm 6$ & $2,48 \pm 0,05$ \\
\hline 460 & $535 \pm 44$ & $192 \pm 46$ & $154 \pm 21$ & $64 \pm 9$ & $71 \pm 4$ & $2,50 \pm 0,07$ \\
\hline
\end{tabular}

A operação em batelada (volume a ser tratado totalmente preenchido em 10 $\min , \mathrm{t}_{\mathrm{F}}=0$ ) foi considerada padrão de comparação. Valores médios de remoção de 78 e $70 \%$ foram obtidos para amostras filtradas e não filtradas, respectivamente. Esse patamar de eficiência foi mantido nas operações batelada alimentada seguida de batelada, com tempos de enchimento de $120 \min (81$ e $71 \%$ ) e $240 \min (78$ e $72 \%)$. As demais condições experimentais não apresentaram bom desempenho. No entanto, se comparada ao protocolo anteriormente apresentado (RATUSZNEI et al., 2003), a configuração utilizada apresenta estabilidade operacional em todas as condições investigadas e, conseqüentemente é mais eficiente. Os pesquisadores obtiveram eficiências de remoção médias (para amostras filtradas) de $86 \%\left(\mathrm{t}_{\mathrm{F}} / \mathrm{t}_{\mathrm{C}}=0\right.$, batelada), $72 \%\left(\mathrm{t}_{\mathrm{F}} / \mathrm{t}_{\mathrm{C}}=0,17\right), 68 \%\left(\mathrm{t}_{\mathrm{F}} / \mathrm{t}_{\mathrm{C}}=0,33\right)$ e $69 \%\left(\mathrm{t}_{\mathrm{F}} / \mathrm{t}_{\mathrm{C}} \cong 1\right.$, batelada alimentada). É importante salientar que a diferença entre os dois sistemas consiste no preenchimento do leito contendo biomassa imobilizada: no trabalho supracitado a alimentação era 
feita uniformemente, ao longo dos tempos de carregamento propostos; já na configuração aqui apresentada, o leito encontrava-se sempre submerso, devido ao carregamento de 1,5 L de água residuária, realizado no início de cada ciclo (10 minutos iniciais).

TABELA 5.12: Variáveis monitoradas no reator para as diferentes estratégias de alimentação.

\begin{tabular}{ccccccc}
\hline \multirow{2}{*}{$\mathbf{t}_{\mathbf{F}}^{*}(\mathbf{m i n})$} & \multicolumn{2}{c}{$\mathbf{A B}(\mathbf{m g C a C O} / \mathbf{L})$} & \multicolumn{2}{c}{$\mathbf{A V T}(\mathbf{m g H A c} / \mathbf{L})$} & \multicolumn{2}{c}{$\mathbf{p H}$} \\
\cline { 2 - 7 } & Afluente $^{(a)}$ & Efluente $^{(b)}$ & Afluente $^{(a)}$ & Efluente $^{(b)}$ & Afluente $^{(a)}$ & Efluente $^{(b)}$ \\
\hline 0 & $113 \pm 3$ & $192 \pm 5$ & $27 \pm 3$ & $18 \pm 4$ & $8,7 \pm 0.2$ & $7,3 \pm 0.2$ \\
120 & $119 \pm 13$ & $184 \pm 14$ & $28 \pm 3$ & $21 \pm 6$ & $8,4 \pm 0.8$ & $7,4 \pm 0.1$ \\
240 & $127 \pm 5$ & $193 \pm 12$ & $30 \pm 3$ & $20 \pm 5$ & $8,8 \pm 0.3$ & $7,2 \pm 0.2$ \\
360 & $128 \pm 11$ & $198 \pm 11$ & $30 \pm 2$ & $23 \pm 2$ & $8,4 \pm 0.7$ & $7,5 \pm 0.2$ \\
460 & $126 \pm 9$ & $191 \pm 15$ & $32 \pm 5$ & $23 \pm 3$ & $8,2 \pm 0.7$ & $7, .3 \pm 0.1$
\end{tabular}

"t $\mathbf{t}_{\mathbf{F}}-$ Tempo de duração da batelada alimentada. Tempo total do ciclo: $480 \mathrm{~min}$.

Número de amostras: ${ }^{(a)} 6 / 9 / 7 / 9 / 10 ;{ }^{b)} 9 / 10 / 7 / 10 / 8$.

A análise da Tabela 5.12 permite a constatação de que a limitação do fornecimento de substrato, imposta pela adoção de tempos de enchimento longos (120, 240, 360 e 460 min), não permitiu o acúmulo de ácidos voláteis totais no reator, este fato é comprovado pelo balanço entre consumo e produção de AVT e de $\mathrm{AB}$, observados em todas as condições estudadas. Os baixos valores de desviopadrão nas medidas de alcalinidade, os valores $\mathrm{AI} / \mathrm{AP} \leq 0,3$ e a manutenção do $\mathrm{pH}$ no efluente próximo a 7,0 indicam a estabilidade do sistema. 
Comparativamente, o trabalho anteriormente realizado, enfocando o uso da batelada alimentada em ASBR com biomassa imobilizada (RATUSZNEI et al., 2003) apresentou problemas de estabilidade operacional no sistema, particularmente nas operações com $t_{\mathrm{F}} / t_{\mathrm{C}}>0,33$, nas quais foram registradas concentrações crescentes de ácidos voláteis totais.

A formação do material polimérico viscoso, de provável origem biológica, pode ser citada como fator adverso na operação do sistema, principalmente nas últimas condições pesquisadas $\left(\mathrm{t}_{\mathrm{F}} / \mathrm{t}_{\mathrm{C}}=0,75\right.$ e $\left.\mathrm{t}_{\mathrm{F}} / \mathrm{t}_{\mathrm{C}} \cong 1\right)$, em que o material se apresentava denso e em grande quantidade. Sabe-se que em condições operacionais desfavoráveis, a produção de polímeros extracelulares (PEC) pode ser associada a uma provável estratégia de sobrevivência adotada pelos microrganismos. O acúmulo desse material, também citado por RATUSZNEI et al (2003), é visualizado nas Figuras 5.54, 5.55 e 5.56, que apresentam fotografias obtidas ao final da última condições pesquisada $\left(t_{\mathrm{F}} / \mathrm{t}_{\mathrm{C}} \cong 1\right)$.

As Tabelas 5.13 e 5.14 contêm os dados relativos a monitoração de sólidos no afluente, efluente e na biomassa imobilizada. 


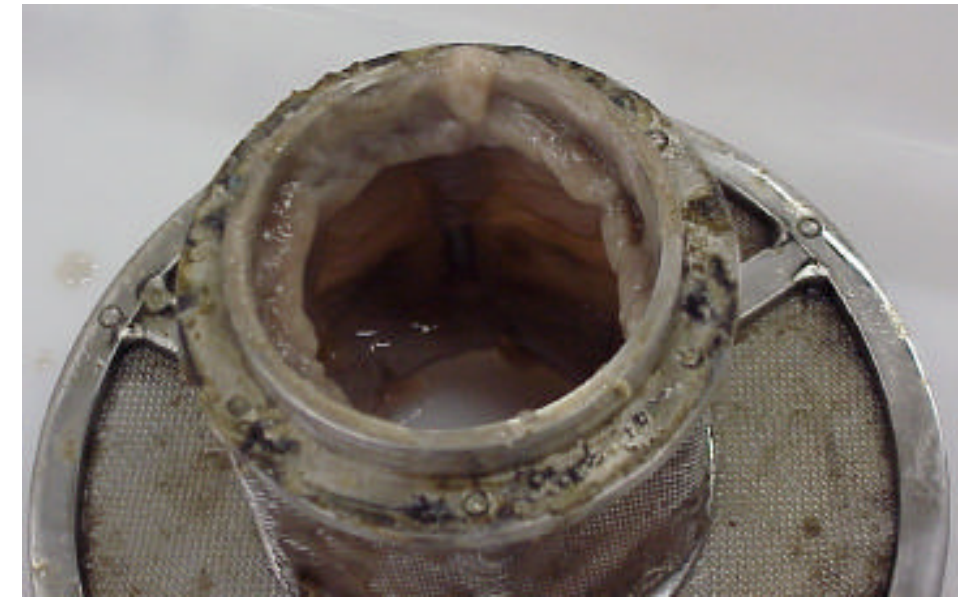

FIGURA 5.54: Fotografia do material polimérico viscoso presente no cilindro onde foi alocado o eixo de agitação, ao final do ensaio em batelada alimentada ( $8 \mathrm{~h})$.

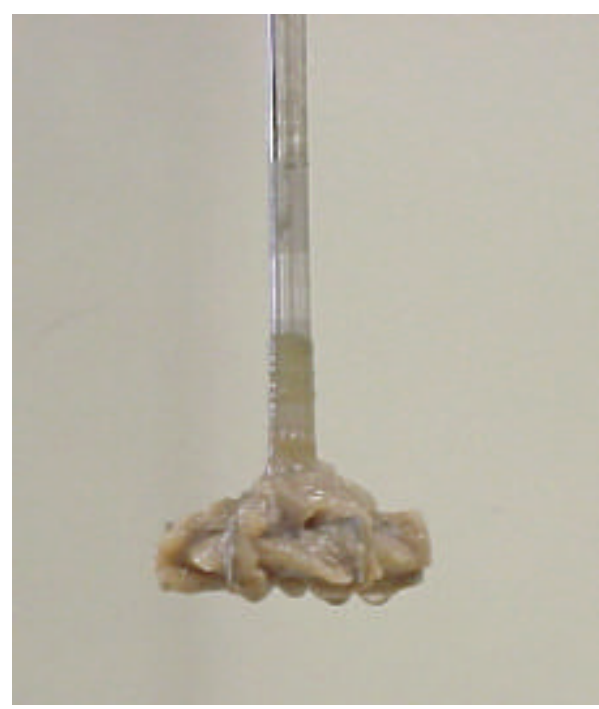

FIGURA 5.55: Fotografia do material polimérico presente no impelidor e no eixo de agitação ao final do ensaio em batelada $(8 \mathrm{~h})$. 


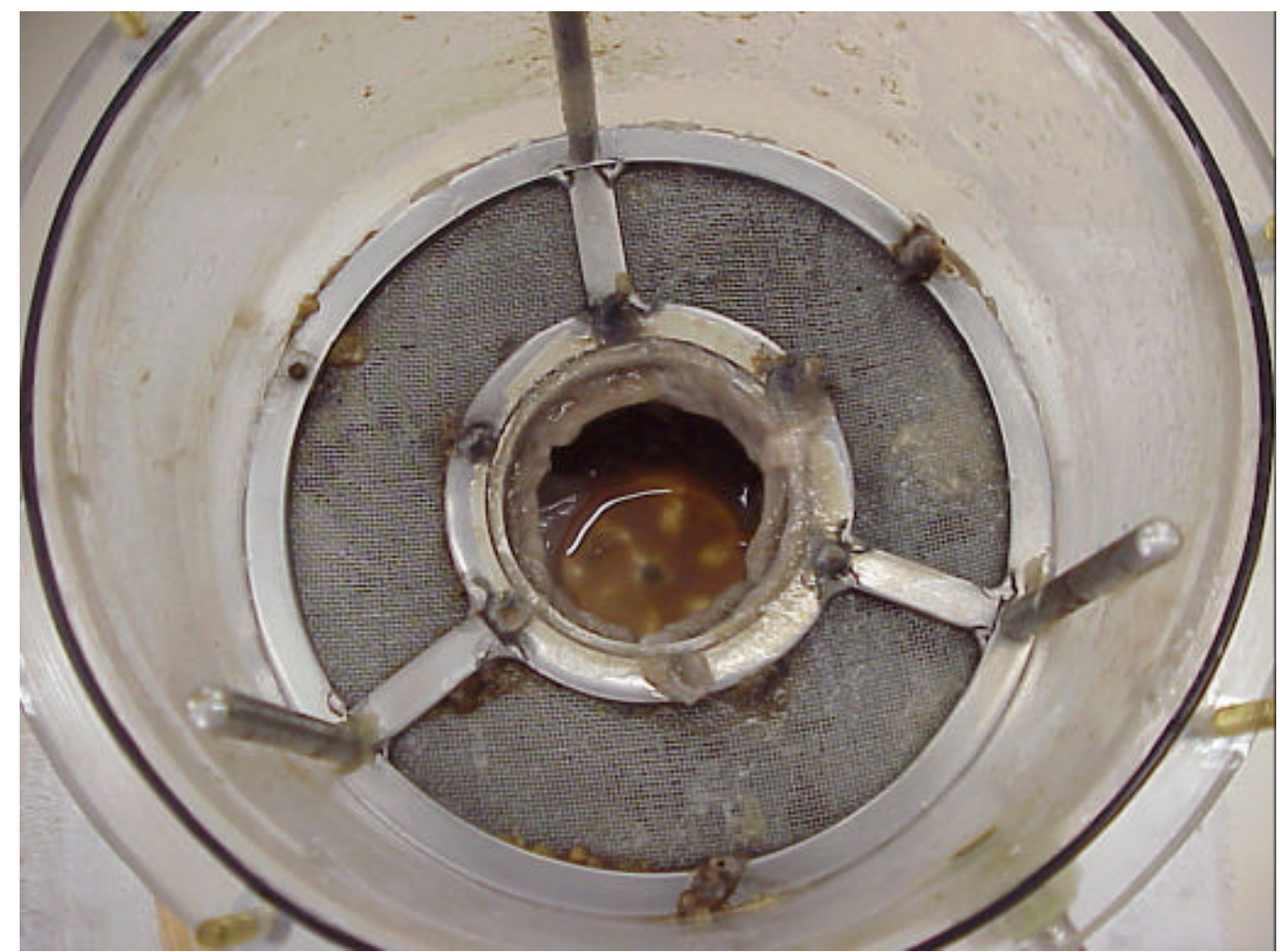

FIGURA 5.56: Vista superior do sistema, com formação de polímeros extracelulares, ao final do ensaio em batelada $(8 \mathrm{~h})$.

TABELA 5.13: Variáveis monitoradas no reator para as diferentes estratégias de alimentação.

\begin{tabular}{|c|c|c|c|c|c|c|c|c|}
\hline \multirow{2}{*}{$\mathbf{t}_{\mathbf{F}}^{*}(\min )$} & \multicolumn{2}{|c|}{$\mathrm{ST}^{(a)}(\mathrm{mg} / \mathrm{L})$} & \multicolumn{2}{|c|}{$\mathrm{SVT}^{(a)}(\mathrm{mg} / \mathrm{L})$} & \multicolumn{2}{|c|}{$\operatorname{SST}^{(a)}(\mathrm{mg} / \mathrm{L})$} & \multicolumn{2}{|c|}{$\operatorname{SSV}^{(a)}(\mathrm{mg} / \mathrm{L})$} \\
\hline & Afluente & Efluente & Afluente & Efluente & Afluente & Efluente & Afluente & Efluente \\
\hline 0 & $863 \pm 106$ & $687 \pm 145$ & $500 \pm 116$ & $317 \pm 139$ & $29 \pm 17$ & $48 \pm 14$ & $20 \pm 13$ & $32 \pm 14$ \\
\hline 120 & $945 \pm 118$ & $688 \pm 53$ & $484 \pm 56$ & $266 \pm 79$ & $49 \pm 16$ & $55 \pm 22$ & $29 \pm 15$ & $32 \pm 16$ \\
\hline 240 & $900 \pm 60$ & $616 \pm 34$ & $485 \pm 55$ & $215 \pm 55$ & $58 \pm 29$ & $53 \pm 22$ & $49 \pm 32$ & $38 \pm 21$ \\
\hline 360 & $987 \pm 109$ & $688 \pm 55$ & $516 \pm 58$ & $240 \pm 73$ & $70 \pm 29$ & $53 \pm 23$ & $47 \pm 22$ & $32 \pm 15$ \\
\hline 460 & $1002 \pm 61$ & $786 \pm 143$ & $518 \pm 60$ & $252 \pm 41$ & $62 \pm 29$ & $54 \pm 29$ & $49 \pm 24$ & $32 \pm 28$ \\
\hline
\end{tabular}

't $\mathbf{t}_{\mathbf{F}}$ - Tempo de duração da batelada alimentada. Tempo total do ciclo: $480 \mathrm{~min}$. 
A remoção de sólidos ocorreu na maioria das estratégias (Tabela 5.13), todavia, a utilização do substrato preparado sinteticamente, com baixos valores de sólidos (média inferior a $1 \mathrm{gST} / \mathrm{L}$ ) não permite uma análise mais rigorosa nesse sentido.

TABELA 5.14: Sólidos presentes no reator monitorados durante diferentes estratégias de alimentação.

\begin{tabular}{|c|c|c|c|c|c|c|c|c|}
\hline \multirow{2}{*}{$\begin{array}{c}\mathbf{t}_{\mathbf{F}}^{*} \\
(\mathbf{m i n})\end{array}$} & \multicolumn{8}{|c|}{ Parâmetro } \\
\hline & $\begin{array}{c}\mathrm{ST}^{(a)} \\
(\mathrm{mg} / \mathrm{g})\end{array}$ & $\begin{array}{l}\mathrm{SVT}^{(a)} \\
(\mathrm{mg} / \mathrm{g})\end{array}$ & $\begin{array}{c}\mathbf{S T}^{(b)} \\
(\mathrm{g})\end{array}$ & $\begin{array}{c}\text { SVT }^{(b)} \\
(g)\end{array}$ & $\begin{array}{l}\mathrm{ST}^{(c)} \\
(\mathrm{g} / \mathrm{L})\end{array}$ & $\begin{array}{r}\text { SVT }^{(c)} \\
(\mathrm{g} / \mathrm{L})\end{array}$ & $\begin{array}{c}\mathbf{M}_{\text {Total }}^{(d)} \\
\mathbf{g}\end{array}$ & $\begin{array}{c}\mathbf{M}_{\text {esp limpa }}^{(e)} \\
\mathrm{g}\end{array}$ \\
\hline 120 & 1164 & 1018 & 18,3 & 16,0 & 7,3 & 6,4 & 991 & 15,7 \\
\hline 240 & 960 & 707 & 18,5 & 13,7 & 7,4 & 5,5 & 992 & 19,3 \\
\hline 360 & 973 & 850 & 15,0 & 13,1 & 6,0 & 5,2 & 934 & 15,4 \\
\hline 460 & 782 & 608 & 15,1 & 11,8 & 6,0 & 4,7 & 1084 & 19,3 \\
\hline
\end{tabular}

Através dos dados apresentados na Tabela 5.14, observa-se que o valor médio de sólidos voláteis totais (SVT) no reator equivale a 13,7 g; este valor é um indicativo da quantidade de biomassa imobilizada presente no sistema. Devido à diferença nas configurações utilizadas, registra-se uma discrepância nos valores encontrados, comparando-se com o trabalho de RATUSZNEI et al. (2003) que reportaram um valor médio de 43,5 gSVT no reator então utilizado. 
Ressalta-se que o principal problema operacional relatado no trabalho supracitado foi o fato da biomassa imobilizada ser submetida a um carregamento uniforme muito lento, ocasionando na perda de contato entre substrato e microrganismos, quando tempos de enchimento longos foram implementados.

A configuração neste trabalho permitiu o preenchimento de todo o leito em um tempo pequeno em relação ao tempo do ciclo (10 minutos); só então a alimentação adicional era iniciada. Entretanto a diminuição do cesto onde a espuma de poliuretano com biomassa imobilizada foi alocada acarretou em uma concentração de sólidos baixa, comparada a sistemas similares, no reator.

Com os resultados alcançados, observa-se que a configuração adotada pode ser utilizada em estratégias de alimentação variadas, salientando-se a necessidade de um incremento na concentração de biomassa no reator. A flexibilidade operacional proporcionada pela adoção da batelada alimentada pode ser citada como motivação para o estudo deste tipo de sistema.

\subsection{Estudo cinético para os experimentos com diferentes estratégias de alimentação}

Um modelo cinético de primeira ordem foi ajustado aos dados experimentais obtidos nos perfis de concentração de matéria orgânica, considerando-se amostras filtradas. O parâmetro cinético $\mathrm{k}_{1}$, obtido para as várias estratégias de alimentação pesquisadas é uma constante classificada como aparente, pois inclui em sua síntese as resistências à transferência de massa interna e externa aos grânulos além do fenômeno de reação bioquímica. 
As Figuras 5.57 a 5.61 representam os perfis dinâmicos para concentração de matéria orgânica contendo valores experimentais obtidos nas amostragens e valores ajustados pelo modelo. Todos os ajustes cinéticos foram realizados utilizando-se dois procedimentos: (i) estimativa do parâmetro cinético aparente $\mathrm{k}_{1}$ pelo ajuste do modelo aos dados experimentais, mantendo-se os valores para concentração de substrato residual $\left(\mathrm{C}_{\mathrm{SR}}\right)$ iguais as médias obtidas através dos experimentos; e (ii) estimativa de ambos, parâmetro cinético aparente $\left(\mathrm{k}_{1}\right)$ e concentração de substrato residual $\left(\mathrm{C}_{\mathrm{SR}}\right)$ pelo ajuste do modelo aos dados experimentais.

Os dados obtidos através do ajuste cinético estão contidos no Apêndice V.

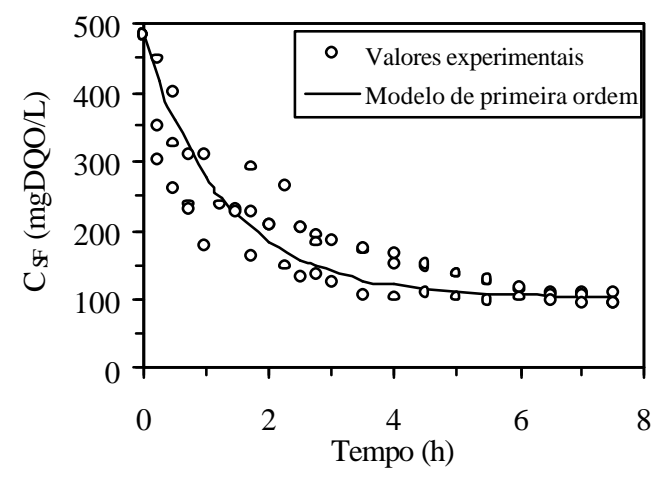

(a)

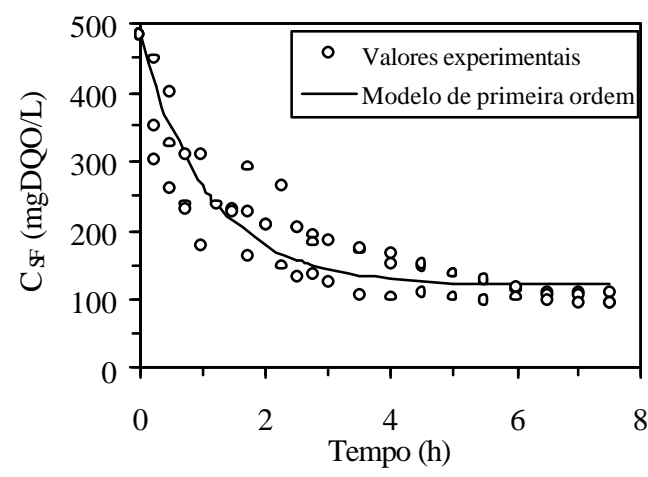

(b)

FIGURA 5.57: Ajuste dos perfis obtidos para a operação em batelada ( 8 h). (a) $\mathrm{k}_{1}$ estimado e $\mathrm{C}_{\mathrm{SR}}$ experimental, (b) $\mathrm{k}_{1}$ e $\mathrm{C}_{\mathrm{SR}}$ estimados. 


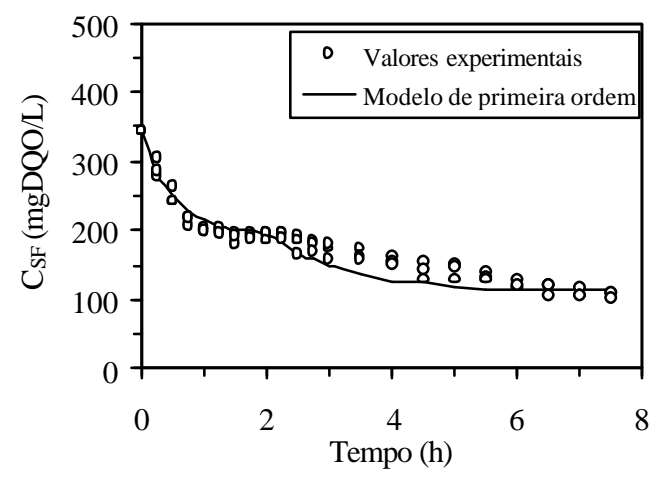

(a)

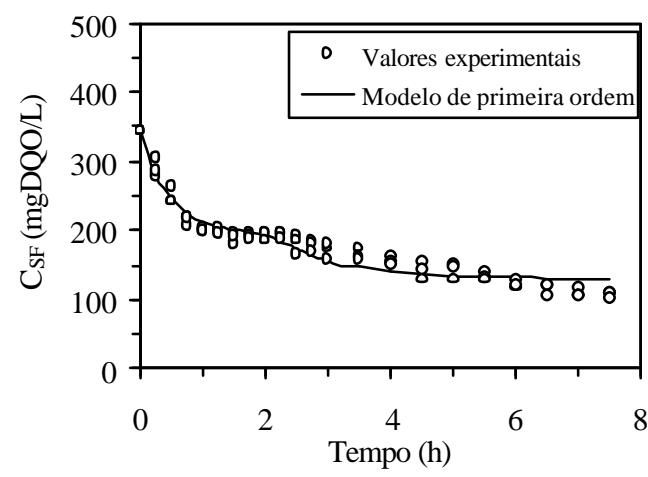

(b)

FIGURA 5.58: Ajuste dos perfis obtidos para a operação em batelada alimentada ( $2 \mathrm{~h}$ ) seguida de batelada (6 h). (a) $\mathrm{k}_{1}$ estimado e $\mathrm{C}_{\mathrm{SR}}$ experimental, (b) $\mathrm{k}_{1}$ e $\mathrm{C}_{\mathrm{SR}}$ estimados.

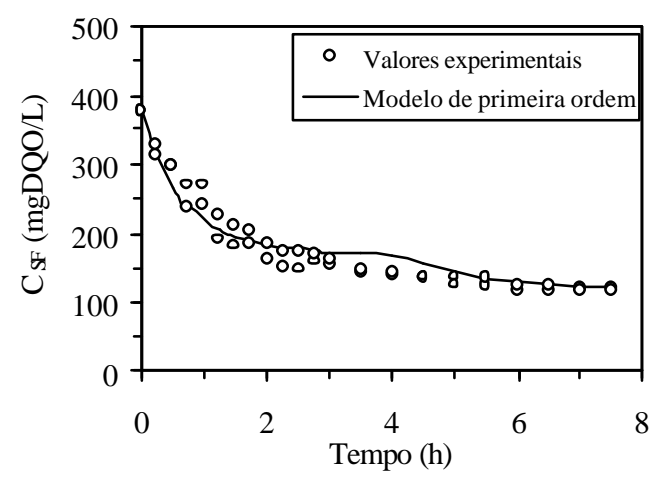

(a)

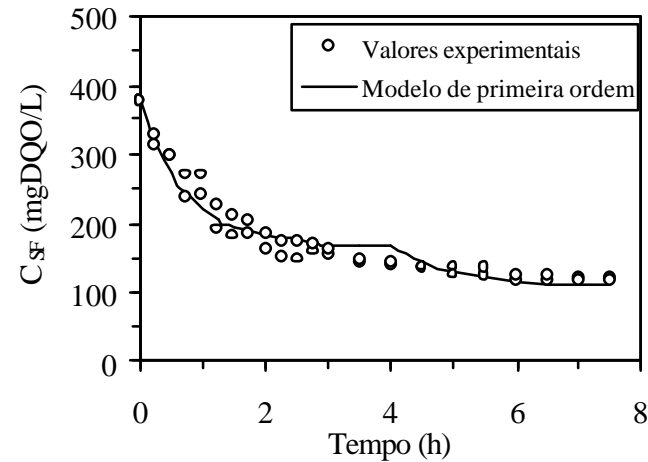

(b)

FIGURA 5.59: Ajuste dos perfis obtidos para a operação em batelada alimentada

(4 h) seguida de batelada (4 h). (a) $\mathrm{k}_{1}$ estimado e $\mathrm{C}_{\mathrm{SR}}$ experimental, (b) $\mathrm{k}_{1}$ e $\mathrm{C}_{\mathrm{SR}}$ estimados. 


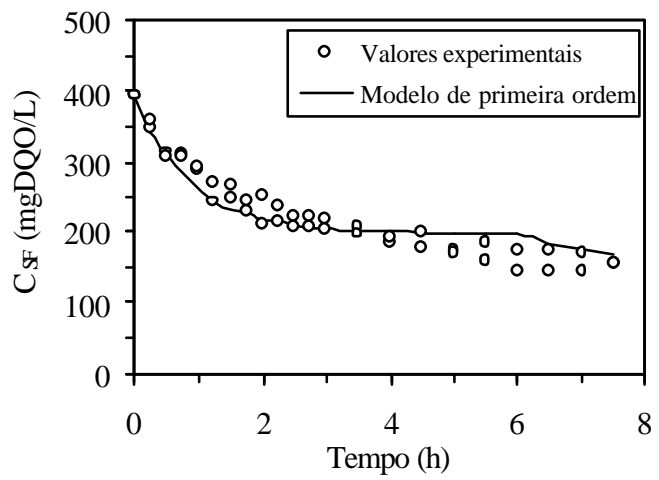

(a)

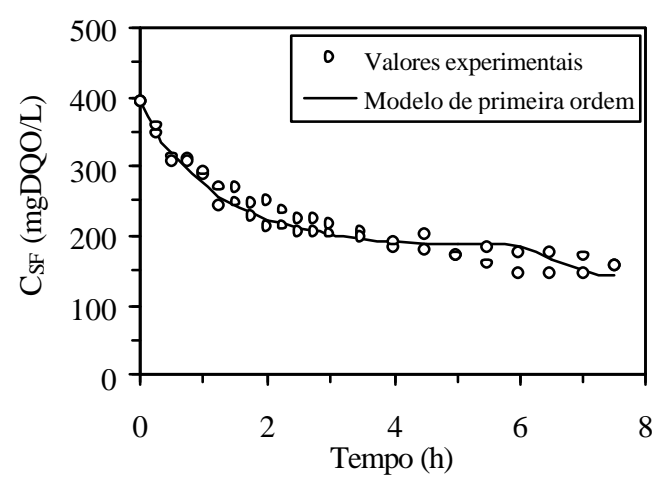

(b)

FIGURA 5.60: Ajuste dos perfis obtidos para a operação em batelada alimentada (6 h) seguida de batelada ( 2 h). (a) $\mathrm{k}_{1}$ estimado e $\mathrm{C}_{\mathrm{SR}}$ experimental, (b) $\mathrm{k}_{1}$ e $\mathrm{C}_{\mathrm{SR}}$ estimados.

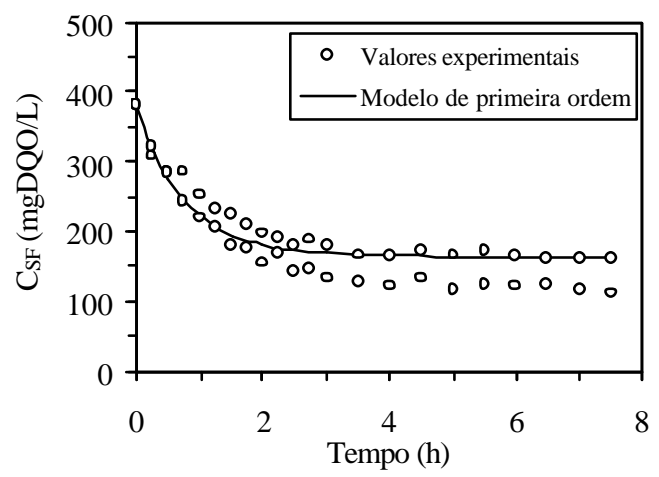

(a)

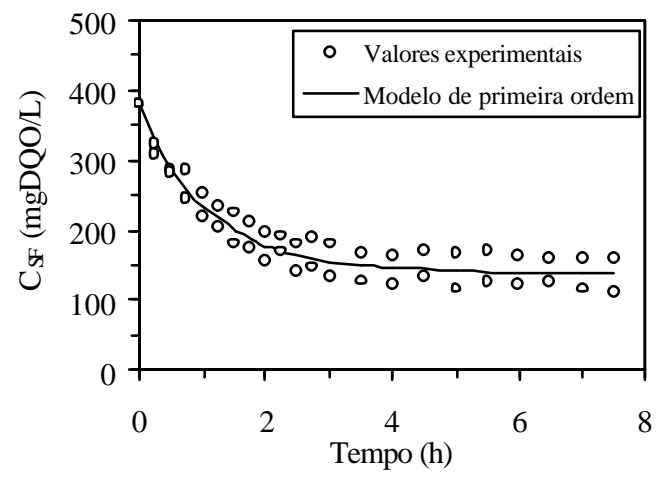

(b)

FIGURA 5.61: Ajuste dos perfis obtidos para a operação em batelada alimentada ( 8 h). (a) $\mathrm{k}_{1}$ estimado e $\mathrm{C}_{\mathrm{SR}}$ experimental, (b) $\mathrm{k}_{1}$ e $\mathrm{C}_{\mathrm{SR}}$ estimados.

Os valores obtidos para os coeficientes cinéticos aparentes e para as concentrações residuais são apresentados na Tabela 5.15. 
TABELA 5.15: Valores obtidos pelo modelo ajustado aos dados experimentais.

\begin{tabular}{|c|c|c|c|c|c|c|c|c|}
\hline \multirow[t]{2}{*}{$\mathbf{t}_{\mathbf{F}}^{(a)}$} & \multicolumn{4}{|c|}{$\begin{array}{c}\text { Ajuste 1 } \\
\mathrm{k}_{1} \text { estimado e } \mathrm{C}_{\mathrm{SR}} \text { experimental }\end{array}$} & \multicolumn{4}{|c|}{$\begin{array}{c}\text { Ajuste 2 } \\
\mathrm{k}_{1} \text { e } \mathrm{C}_{\mathrm{SR}} \text { estimados }\end{array}$} \\
\hline & $k_{1}{ }^{(b)}$ & $\mathrm{C}_{\mathrm{SR}}{ }^{\operatorname{Exp}(c)}$ & $\mathbf{R}^{2(d)}$ & $\overline{\mathrm{IQE}^{(e)}}$ & $\overline{\mathbf{k}_{1}}$ & $\mathbf{C}_{\mathbf{S R}}^{(f)}$ & $\mathbf{R}^{2}$ & $\overline{\mathrm{IQE}}$ \\
\hline 0 & $0,142 \pm 0,007$ & 103 & 0,976 & $8058^{(16)}$ & $0,168 \pm 0,011$ & $121 \pm 5$ & 0,972 & $6052^{(16)}$ \\
\hline 120 & $0,172 \pm 0,008$ & 111 & 0,956 & $4754^{(19)}$ & $0,209 \pm 0,012$ & $130 \pm 3$ & 0,956 & $3088^{(19)}$ \\
\hline 240 & $0,150 \pm 0,007$ & 120 & 0,977 & $3607^{(17)}$ & $0,133 \pm 0,006$ & $107 \pm 4$ & 0,977 & $2388^{(17)}$ \\
\hline 360 & $0,121 \pm 0,006$ & 159 & 0,953 & $4849^{(18)}$ & $0,086 \pm 0,004$ & $127 \pm 5$ & 0,977 & $1779^{(18)}$ \\
\hline 460 & $0,139 \pm 0,007$ & 140 & 0,966 & $4966^{(17)}$ & $0,096 \pm 0,002$ & $99 \pm 2$ & 0,996 & $383^{(17)}$ \\
\hline & 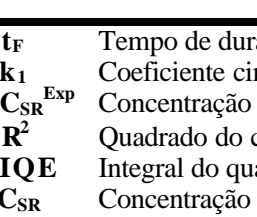 & 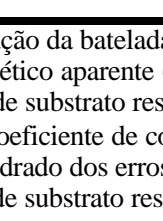 & elaç & $T$ & S & $\begin{array}{l}\text { a os d } \\
\text { L). } \\
\text { lizado: } \\
\text { l/L). }\end{array}$ & saios. & \\
\hline
\end{tabular}

Através das Figuras 5.53 a 5.57 observa-se que o segundo procedimento $\left(\mathrm{C}_{\mathrm{SR}}\right.$ e $k_{1}$ estimados) apresentou melhores resultados, considerando-se a correlação entre o modelo de primeira ordem e os valores experimentais. A análise da Tabela 5.11 ratifica a observação, uma vez que a minimização do IQE foi utilizada como parâmetro de otimização do modelo implementado.

Na Figura 5.62 são visualizados os coeficientes cinéticos aparentes obtidos ao longo dos experimentos propostos: operação em batelada $-8 \mathrm{~h}-\left(\mathrm{t}_{\mathrm{F}} / \mathrm{t}_{\mathrm{C}}=0\right)$; operação em batelada alimentada $-2 \mathrm{~h}-$ seguida de batelada $-6 \mathrm{~h}-\left(\mathrm{t}_{\mathrm{F}} / \mathrm{t}_{\mathrm{C}}=0,25\right)$; operação em batelada alimentada $-4 \mathrm{~h}-$ seguida de batelada $-4 \mathrm{~h}-\left(\mathrm{t}_{\mathrm{F}} / \mathrm{t}_{\mathrm{C}}=0,5\right)$; operação em batelada alimentada $-6 \mathrm{~h}-$ seguida de batelada $-2 \mathrm{~h}-\left(\mathrm{t}_{\mathrm{F}} / \mathrm{t}_{\mathrm{C}}=0,75\right) \mathrm{e}$ operação em batelada alimentada $-8 \mathrm{~h}-\left(\mathrm{t}_{\mathrm{F}} / \mathrm{t}_{\mathrm{C}} \cong 1\right)$. 


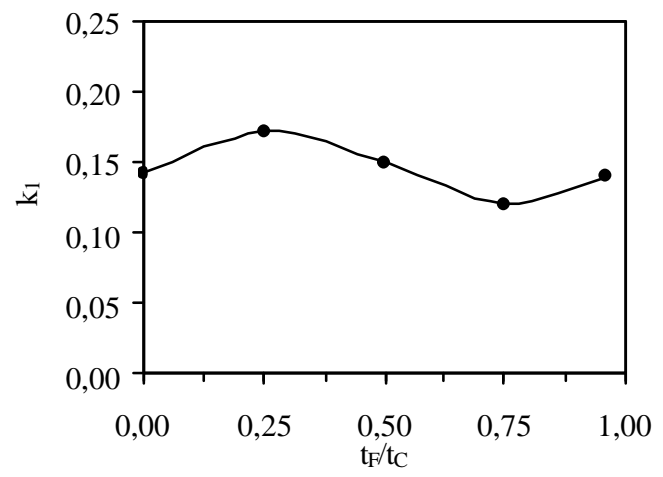

(a)

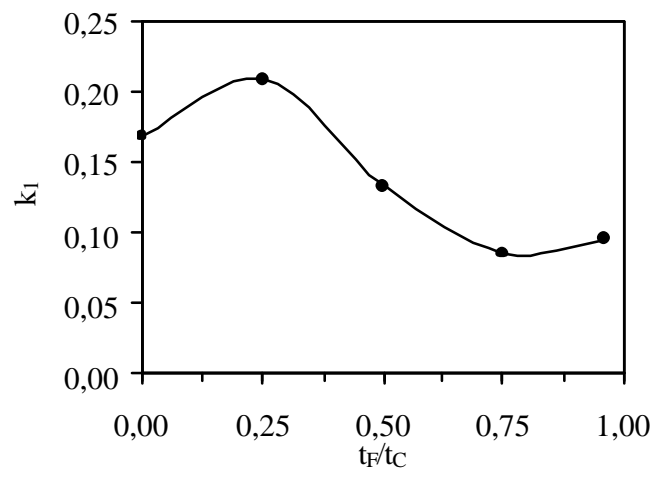

(b)

FIGURA 5.62: Coeficientes cinéticos obtidos para as diferentes estratégias de alimentação. (a) $\mathrm{k}_{1}$ estimado e $\mathrm{C}_{\mathrm{SR}}$ experimental, (b) $\mathrm{k}_{1}$ e $\mathrm{C}_{\mathrm{SR}}$ estimados.

Observa-se que apesar de apresentarem valores absolutos diferentes, as duas análises revelam o mesmo comportamento. Tendo como base os coeficientes obtidos na segunda rotina $\left(\mathrm{C}_{\mathrm{SR}}\right.$ e $\mathrm{k}_{1}$ estimados, em que se obteve melhor ajuste) pode-se afirmar que para os ensaios em que o tempo de enchimento foi igual ou menor que $25 \%$ do tempo do ciclo não houve limitação de fornecimento de substrato, ocasio nando os maiores valores de $\mathrm{k}_{1}(0,168$ e 0,209$)$.

$\mathrm{O}$ aumento no valor do coeficiente cinético quando o parâmetro $\mathrm{t}_{\mathrm{F}} / \mathrm{t}_{\mathrm{C}}$ passou de 0 para 0,25 foi provavelmente ocasionado pela melhor condição de mistura no reator devido à adição gradual de água residuária. A partir desse ponto registra-se queda nos valores do coeficiente aparente devido à limitação do metabolismo pelo fornecimento de substrato cada vez mais lento. Para as duas últimas condições pesquisadas, praticamente não houve variação no parâmetro $k_{1}$ estimado. Os valores estimados de concentração de substrato residual $\left(\mathrm{C}_{\mathrm{SR}}\right)$ não apresentaram correlação estatística com as concentrações de substrato residual experimentais $\left(\mathrm{C}_{\mathrm{SR}}{ }^{\mathrm{Exp}}\right)$. 
A interpretação feita, considerando-se as particularidades da configuração utilizada, sugere a existência de limitações na adoção de tempos de enchimento demasiadamente longos $\left(t_{\mathrm{F}} / \mathrm{t}_{\mathrm{C}}>0,5\right)$ nos reatores anaeróbios operados em batelada tratando águas residuárias de baixa carga.

\subsection{Análises microbiológicas da biomassa imobilizada}

Amostras da biomassa imobilizada em espumas de poliuretano foram coletadas em momentos distintos durante os 218 dias de operação do sistema. Foram feitas coletas durante o ensaio em batelada alimentada ( $2 \mathrm{~h}$ ) seguida de batelada (6 h) e após o término da condição batelada alimentada $(6 \mathrm{~h})$ seguida de batelada $(2 \mathrm{~h})$. As análises de microscopia ótica e contraste de fluorescência foram realizadas no Laboratório de Processos Biológicos da EESC/USP. Nas Figuras 5.63 a 5.69, estão apresentadas as morfologias dos microrganismos imobilizados no suporte inerte utilizado nos experimentos. 


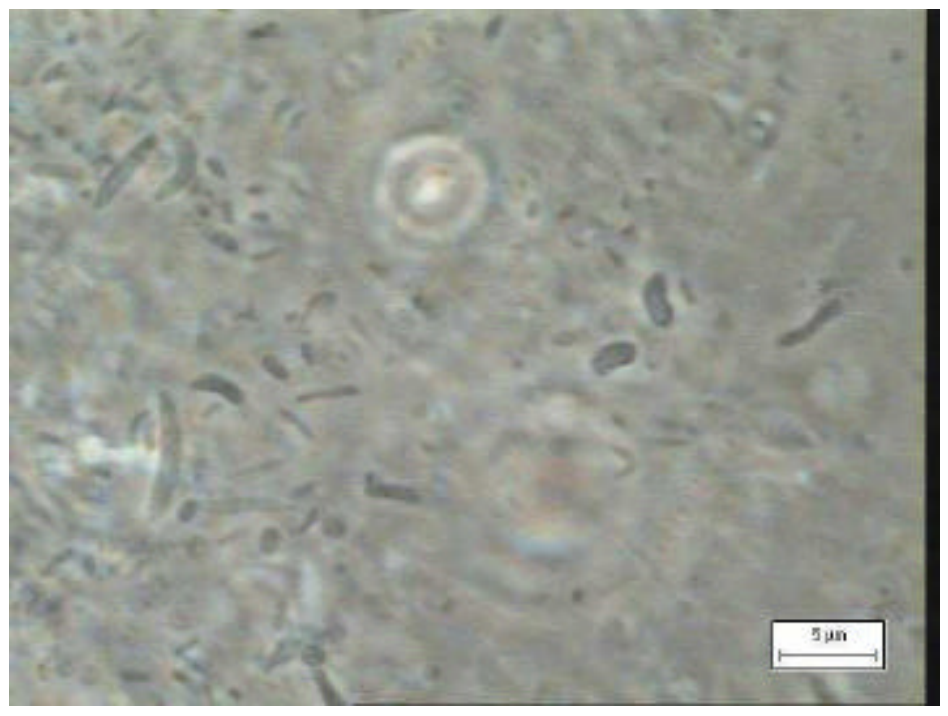

FIGURA 5.63: Morfologias observadas nas espumas de poliuretano através de microscopia ótica: células semelhantes a bacilos e víbrios.

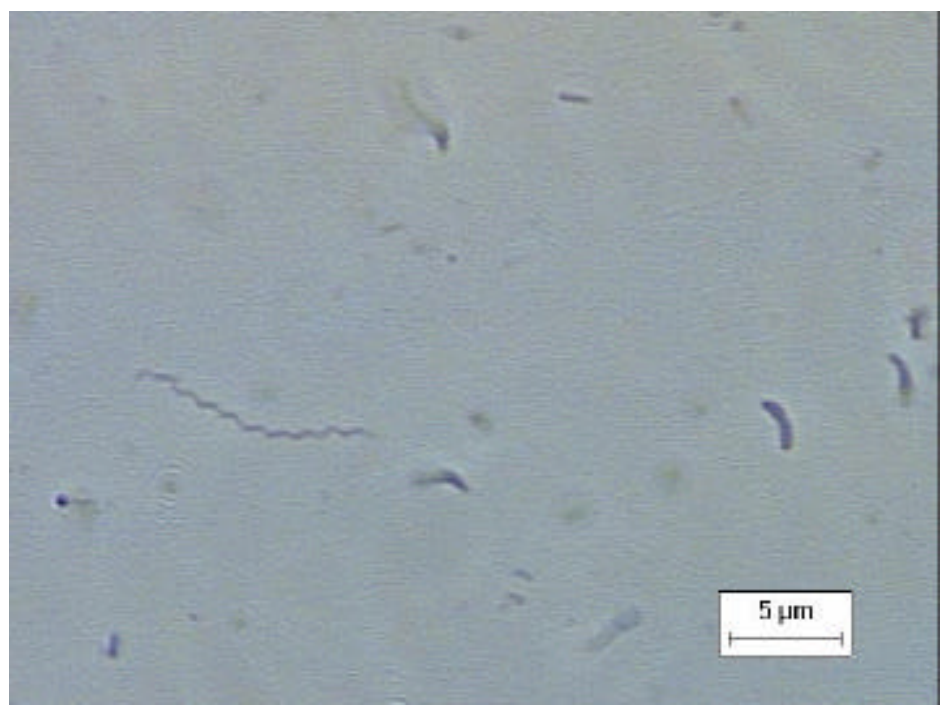

FIGURA 5.64: Morfologias observadas nas espumas de poliuretano através de microscopia ótica: células semelhantes a espiroquetas e víbrios. 


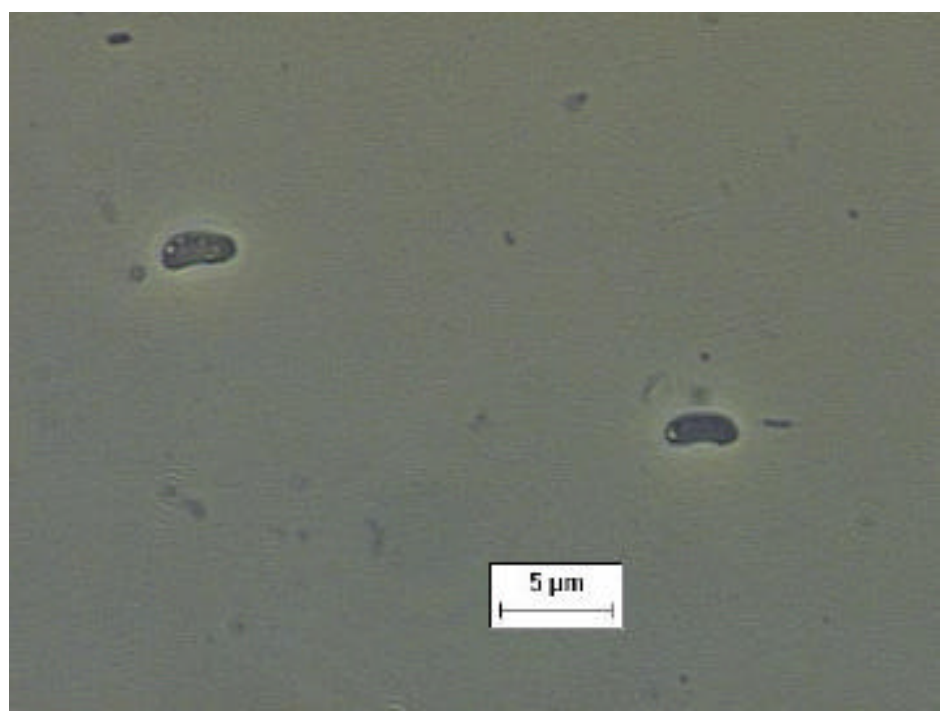

FIGURA 5.65: Morfologias observadas nas espumas de poliuretano através de microscopia ótica: células semelhantes víbrios com inclusões.

As Figuras 5.63, 5.64 e 5.65 ilustram microfotografias dos diversos grupos bacterianos presentes na biomassa imobilizada. Observou-se a presença de espiroquetas, espécies filamentosas e diversos tipos de bacilos e víbrios.

Os microrganismos visualizados nas Figuras 5.66, 5.67 e 5.68 são semelhantes a arqueas metanogênicas. A Figura 5.69 registra a microfotografia de células semelhantes a bacilos fluorescentes hidrogenotróficos. A presença de espécies acetoclásticas e hidrogenotróficas indica o equilíbrio na comunidade metanogênica dentro do consórcio microbiológico responsável pela digestão anaeróbia. 


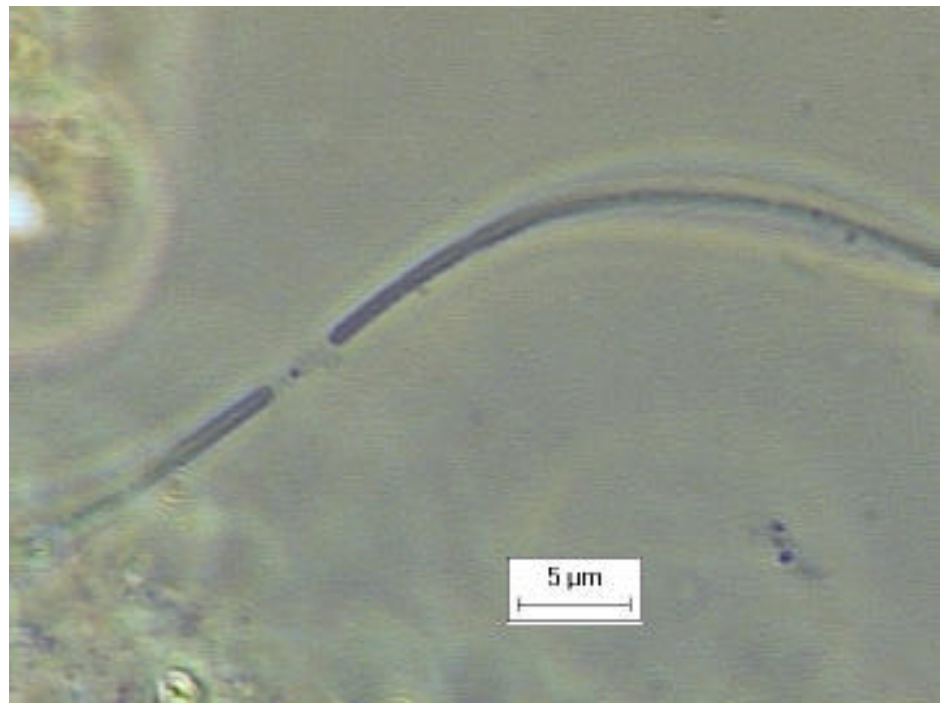

FIGURA 5.66: Morfologia observada nas espumas de poliuretano através de microscopia ótica: célula metanogênica semelhantes a Methanosaeta sp.

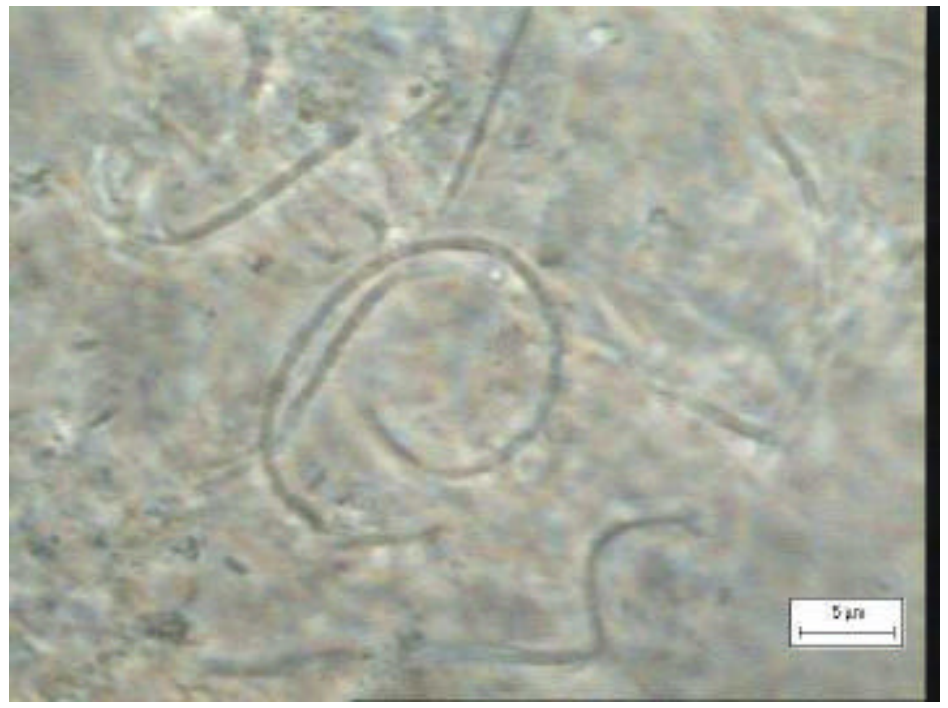

FIGURA 5.67: Morfologias observadas nas espumas de poliuretano através de microscopia ótica: células metanogênicas semelhantes a Methanosaeta sp. 


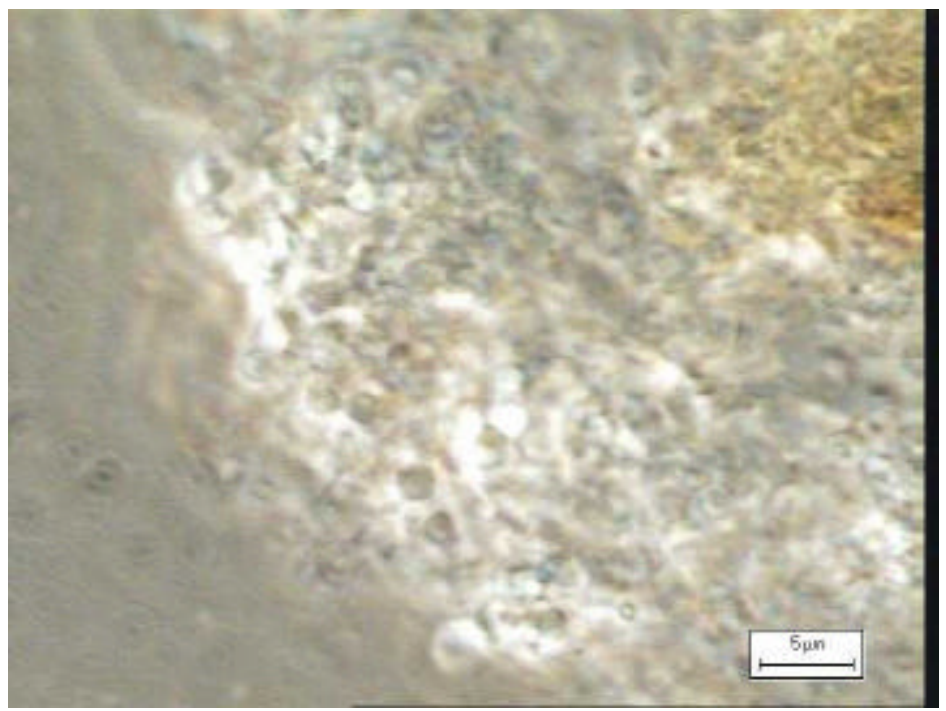

(a)

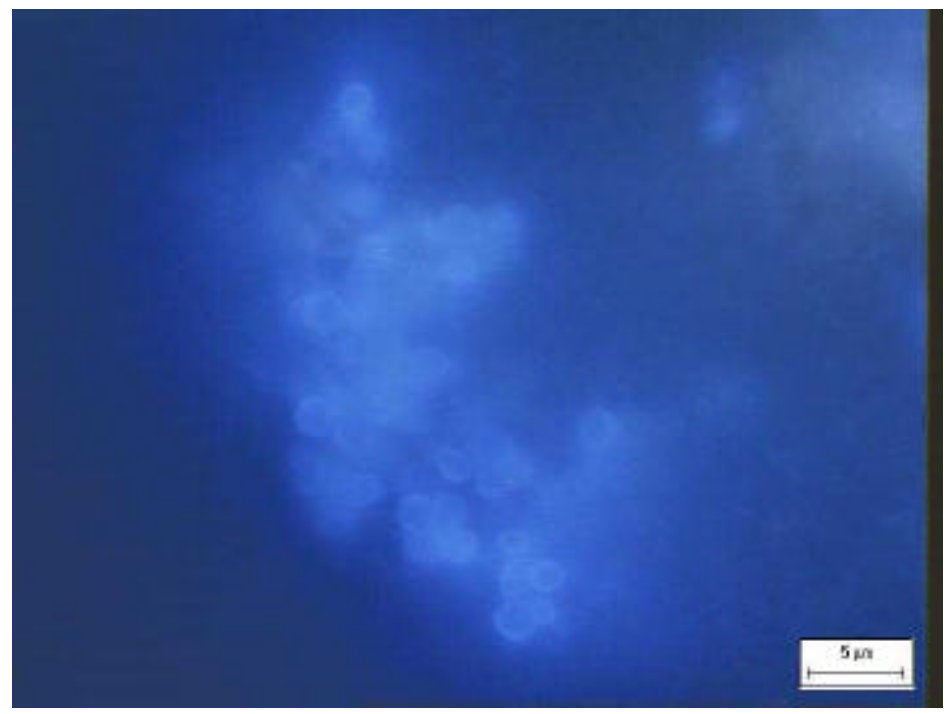

(b)

FIGURA 5.68: Morfologias observadas nas espumas de poliuretano: células semelhantes a Methanosarcina sp. (a) Microscopia ótica, (b) Imagens obtidas por constraste de fase. 


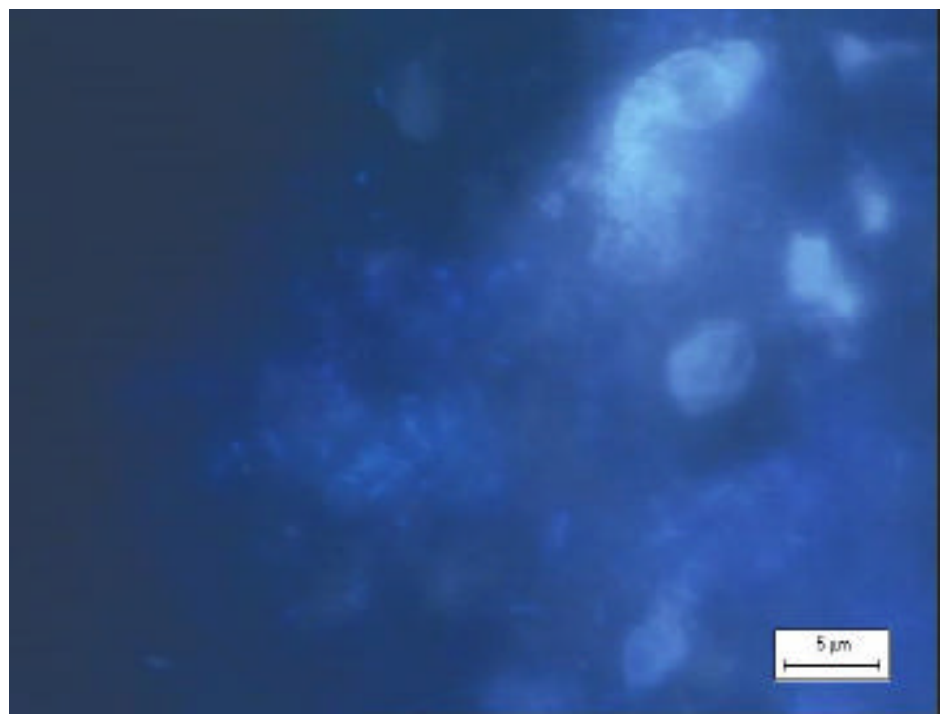

FIGURA 5.69: Morfologias observadas nas espumas de poliuretano através de microscopia ótica (contraste de fase): células semelhantes a bacilos hidrogenotróficos.

Não foi possível constatar diferenças sensíveis nas observações microscópicas entre as amostras feitas em diferentes ocasiões, o que sugere que o aumento do tempo de enchimento, feito a cada condição operacional proposta, não provocou mudanças significativas na fauna microbiana. De uma maneira geral, as morfologias encontradas no biofilme são semelhantes as encontradas nos trabalhos de RATUSZNEI et al. (2003) e VARESCHE et al. (1997). Observa-se que em todas as ocasiões foi usada espuma de poliuretano como suporte inerte apesar das diferentes configurações dos sistemas.

A coleta de material para a análise foi feita em diferentes pontos do ASBR e não observou-se variações na diversidade microbiana para estas amostras. Portanto verifica-se que não houve predominância de um único tipo de microrganismos ao longo da altura do reator. 


\section{CAPÍTULO 6}

\section{CONCLUSÕES E SUGESTÕES}

Os resultados obtidos na operação do reator durante os ensaios propostos, através das análises físicas e bioquímicas, permitem a elaboração das seguintes conclusões:

- O ensaio preliminar realizado, que durou 30 dias, foi importante para a efetuação de ajustes operacionais e para o melhor entendimento do sistema. Os problemas registrados nessa etapa se devem ao fato do estudo enfocar uma tecnologia recente, fato comprovado pela escassez registrada no que diz respeito a trabalhos sobre reatores anaeróbios operados em batelada contendo biomassa imobilizada, particularmente sobre a estratégia de alimentação.

- O patamar de eficiência obtido na operação em batelada, considerada como padrão comparativo, foi mantido nas operações batelada alimentada seguida de batelada, com tempos de enchimento de 120 min e $240 \mathrm{~min}$, ou seja nas condições em que $t_{F} / t_{C} \leq 0,5$. As demais condições experimentais não se mostraram eficientes, registrou-se queda na produção e na porcentagem de metano no biogás produzido. 
- O surgimento de um material viscoso com características poliméricas sugere operação sob condições adversas; tal fato é evidenciado pelos valores de concentração de matéria orgânica não filtrada $\left(\mathrm{C}_{\mathrm{ST}}\right)$.

- A produção de alcalinidade a bicarbonato e o não acúmulo de ácidos orgânicos voláteis, verificados em todas os ensaios realizados, indicam que o sistema se apresentou estável. Os baixos valores de desvio-padrão nas medidas de alcalinidade, os valores AI/AP $\leq 0,3$ e a manutenção do $\mathrm{pH}$ no efluente acima de 7,0 confirmam essa observação.

- A espuma de poliuretano mostrou-se eficaz na formação do biofilme fixo

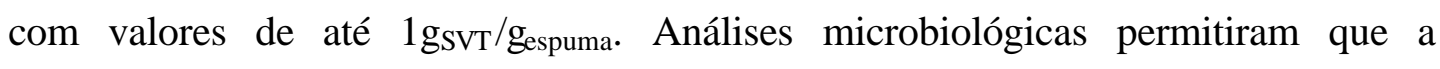
presença dos diversos grupos bacterianos no biofilme fosse avaliada; contudo as limitações inerentes à configuração do sistema não permitiram que a quantidade de microrganismos por volume tratado fosse incrementada (o máximo obtido foi $\left.6,4 \mathrm{~g}_{\mathrm{SVT}} / \mathrm{L}\right)$

- O aumento do tempo de enchimento, feito a cada condição operacional proposta, não provocou mudanças significativas na fauna microbiana. A morfologia dos microrganismos presentes no sistema se mostrou diversificada. Registrou-se a presença de diversos tipos de bacilos e víbrios, além de arqueas metanogênicas acetoclásticas e hidrogenotróficas. Quanto à distribuição dos microrganismos metanogênicos, notou-se um equilíbrio entre os gêneros Methanosaeta sp e Methanosarcina sp aderidos ao suporte inerte. Verifica-se que não houve predominância de um único tipo de microrganismo ao longo da altura do reator. 
- As rotas de degradação da matéria orgânica foram analisadas através dos perfis dinâmicos. O modelo de primeira ordem contemplando as fases batelada e batelada alimentada conseguiu descrever a cinética do processo nos experimentos realizados. $\mathrm{O}$ valor do coeficiente $\mathrm{k}_{1}$ aumentou com a implantação de um tempo de enchimento complementar de $120 \mathrm{~min}$, isto se deve, provavelmente a uma melhor condição de mistura no reator devido à adição gradual de água residuária. Contudo observou-se a partir desse ponto queda nos valores do coeficiente aparente devido ao controle do fornecimento de substrato primário em níveis baixos.

- Os resultados obtidos com a utilização de tempos de enchimento maiores vislumbram a aplicação do sistema em escala plena incorporando vantagens como diminuição ou eliminação de tanques de equalização e mobilidade operacional.

Com base nos resultados obtidos e na experiência de condução do trabalho sugere-se a continuidade de pesquisas enfocando o tema, abordando-se os seguintes aspectos:

- Aumento da quantidade de biomassa ativa no tipo de configuração adotada.

- Elucidação dos mecanismos de formação de polímeros extracelulares nesse tipo de biofilme.

- Operação do reator em batelada alimentada seqüe ncial com a mudança de parâmetros operacionais como tempo de ciclo e carga orgânica volumétrica aplicada. 
- Viabilidade da remoção de nutrientes, como nitrogênio e fósforo, nesse tipo de sistema, com a incorporação de fases anóxicas e aeróbias durante o ciclo de operação.

- Aplicabilidade do reator operado em batelada alimentada seqüencial no tratamento de esgoto sanitário e de diferentes tipos de águas residuárias industriais. 


\section{CAPÍTULO 7}

\section{REFERÊNCIAS BIBLIOGRÁFICAS}

ANDRADE NETO, C. O.; CAMPOS, J. R. (1999). Introdução. In: Tratamento de esgotos sanitários por processo anaeróbio e disposição controlada no solo. CAMPOS, J. R. (coord.). ABES, Rio de Janeiro, pp.1-28.

ANGENENT, L. T.; DAGUE, R. R. (1995). A laboratory- scale comparison of the UASB and ASBR processes. In: 50 ${ }^{\text {th }}$ Purdue Industrial. Wastewater Conference Proceedings, Ann Arbor Press, Chelsea, pp. 365-377.

ANGENENT, L. T.; SUNG, S.; RASKIN, L. (2002). Methanogenic population dynamics during startup of a full-scale anaerobic sequencing batch reactor treating swine waste. Water Research, 36, pp.4648-4654.

AMERICAN PUBLIC HEALTH ASSOCIATION, AMERICAN WATER WORKS ASSOCIATION, WATER ENVIRONMENT FEDERATION (1995). Standard methods for examination of water and wastewater. $19 .^{\text {th }}$ ed., Washington D. C.

BAGLEY, D. M.; BRODKORB, T. S. (1999). Modeling microbial kinetics in an anaerobic sequencing batch reactor- model development and experimental validation. Water Environmental Research, 71, pp.1320-1332. 
BANIK, G. C.; ELLIS, T. G.; DAGUE, R. R. (1997). ASBR treatment of low strength industrial wastewater at psychrophilic temperatures. Water Science and Technology, 36, pp.149-156.

BENEFIELD, C. D.; RANDALL, C. W. (1980). Biological process design for wastewater treatment . Prentice- Hall, Inc. Englewood Cliffs, 526p.

BISHOP, P. (1997) Biofilm structure and kinetics. Water Science and Technology, 36, pp.287-294.

BRITO, A. G.; RODRIGUES, A. C.; MELO, F. L. (1997). Feasibility of a pulsed sequencing batch reactor with an anaerobic aggregated biomass for the treatment of low strength wastewaters. Water Science and Technology, 35, pp.193-198.

CABRAL, A. K. A. (2000). Avaliação do desempenho e estabilidade de um reator anaeróbio horizontal de leito fixo (RAHLF) submetido ao aumento progressivo na concentração de matéria orgânica afluente e a cargas de choque orgânicas. Tese de doutorado. Escola de Engenharia de São Carlos, Universidade de São Paulo. São Carlos, 122p.

CAMARGO, E. F. M. (2000). Tratamento anaeróbio de águas residuárias, em batelada, com microrganismos imobilizados e circulação da fase aquosa. Dissertação de mestrado. Escola de Engenharia de São Carlos, Universidade de São Paulo. São Carlos, 207p.

CAMARGO, E. F. M.; RATUSZNEI, S. M.; RODRIGUES, J. A. D.; ZAIAT, M.; BORZANI, W. (2002). Treatment of low-strength wastewater using immobilized biomass in a sequencing batch external loop reactor: Influence of the medium superficial velocity on the stability and performance. Brazilian Journal of Chemical Engineering. 19, pp.267-275. 
CAMPOS, J. R. (1994). Biomassa fixa: Reatores anaeróbios. In: Anais do III Taller y Seminario Latinoamericano- Tratamiento Anaerobio de Aguas Residuales. VIÑHAS, M.; SOUBES, M.; BORZACCONI, L.; MUXI, L. (eds.), Montevidéo, pp.169-184.

CHANG, D.; HUR, J. M.; CHUNG, T. H. (1994). Digestion of municipal sludge in anaerobic sequencing batch reactor. Water Science and Technology, 30, pp.161170.

CHERNICHARO, C. A. L. (1997). Princípios do tratamento biológico de águas residuárias. Volume 4: Reatores anaeróbios. DESA/UFMG, Belo Horizonte, $245 p$.

CHERNICHARO, C. A. L.; van HAANDEL, A. C.; FORESTI, E.; CYBIS, L. F. (2001). Introdução. In: Pós-tratamento de efluentes de reatores anaeróbios. CHERNICHARO, C. A. L. (coord.). Belo Horizonte, pp.19-34.

COSTERTON, J. W.; LEWANDOWSKI, Z.; CALDWELL, D. E.; KORBER, D. R.; LAPPIN-SCOTT, H. M. (1995). Microbial biofilms. Annuary Review of Microbiology, 49, pp.711-745.

CUBAS, S. A.; FORESTI, E.; RODRIGUES, J. A. D.; RATUSZNEI, S. M.; ZAIAT, M. (2001). Influence of the liquid-phase mass transfer on the performance of a stirred anaerobic sequencing batch reactor containing immobilized biomass. In: Proceedings of $9 .^{\text {th }}$ World Congress of Anaerobic Digestion. Antuérpia, pp.847852.

CYBIS, L. F.; PESCADOR, F. S. (2000). Emprego de reatores sequënciais em batelada anaeróbios (RSBAn) para tratamento de esgoto doméstico. In: Anais do VI Taller y Seminario Latinoamericano de Digestión Anaerobia, FORESTI, E.; 
CHERNICHARO, C. A. L.; KATO, M. T.; FLORÊNCIO, L.; LIMA, E. S. (eds.). Recife, pp.90-97.

DAGUE, R. R.; HABBEN, C. E.; PIDAPARTI, S. R (1992). Initial studies on the anaerobic sequencing batch reactor. Water Science and Technology, 26, 24292432.

DAGUE, R. R.; BANIK, G. C.; ELLIS, G. C. (1998). Anaerobic sequencing batch reactor treatment of dilute watewater at psychrophilic temperatures. Water Environment Research, 70, pp.155-160.

DROSTE, R. L.; MASSÉ, D. I. (1995). Anaerobic treatment in sequencing batch reactor. In: Proceedings of International Symposium on Technology Transfer, Salvador, pp.353-363.

FERNANDES, L.; KENNEDY, K. J.; NING, Z. (1993). Dynamic moleling of substrate degradation in sequencing batch anaerobic reactors (SBAR). Water Research, 27, 1619-1628.

FORESTI, E. (1994). Fundamentos do processo de digestão anaeróbia. In: Anais do III Taller y Seminário Latino Americano- Tratamiento Anaeróbio de Águas Residuales. VIÑHAS, M.; SOUBES, M.; BORZACCONI, L.; MUXI, L. (eds.). Montevideo, pp.97-123.

FORESTI, E.; FLORÊNCIO, L.; van HAANDEL, A. C.; ZAIAT, M.; CAVALCANTI, P. F. F. (1999). Fundamentos do tratamento anaeróbio. In: Tratamento de esgotos sanitários por processo anaeróbio e disposição controlada no solo. CAMPOS, J. R. (coord.). ABES, Rio de Janeiro, pp.29-52.

FREITAS, M. A. V.; SANTOS, A. H. M. (1999). A importância da água e da informação hidrológica. In: Estados das águas no Brasil 1999: perspectivas de 
gestão e informação de recursos hídricos. FREITAS, M. A. V. (org.). SIH/ ANEEL/ MME, SRH/ MMA, Brasília, pp.13-16.

FYNN, G. H.; WHITMORE, T. N. (1984). Retention of methanogens in colonized reticulades polyurethane foam biomass support particle. Biotechnology Letters, $\mathbf{6}$, pp.81-86.

GIJZEN, H. J.; SCHOENMAKERS, T. J. M.; CAERTELING, C. G. M.; VOGELS, G. D. (1988). Anaerobic degradation of papermill sludge in a two-phase digester containing rumen microorganisms and colonized polyurethane foam. Biotechnology Letters, 10, pp.61-66.

GUIOT, S. R.; PAUSS, A.; COSTERTON, J. W. (1992). A structured model of the anaerobic granule consortium. Water Science and Technology, 25, pp.1-10.

HARPER, S.R.; POHLAND, F.G. (1986). Recent developments in hydrogen management during anaerobic biological wastewater treatment. Biotechnology and Bioengineering, 28, 585-602.

HENZE, M.; HARREMÖES, P. (1983). Anaerobic treatment of wastewater in fixed film reactors - a literature review. Water Science and Technology, 15, pp.1-101.

HIRL, R. J.; IRVINE, R. L. (1996). Reductive dechlorination of perchloroethylene (PCE) using anaerobic sequencing batch biofilm reactors (AnSBBR). In: $51 .{ }^{s t}$ Purdue Industrial Waste Conference Proceedings. Ann Arbor Press, Chelsea, pp.-289-295.

HOLLOPETER, J. A.; DAGUE, R. R. (1994). Anaerobic sequencing batch reactor treatment of landfill leachate. In: 49. ${ }^{\text {th }}$ Purdue Industrial Waste Conference Proceedings. Ann Arbor Press, Chelsea, pp.-277-284. 
HUYSMAN, P.; van MEENEN, P.; van ASSCHE, P.; VERSTRAETE, W. (1983). Factors affecting the colonization of non porous and porous packing materials in model upflow methane reactors. Biotechnology Letters, 5, pp.643-648.

KATO, M. T.; FIELD, J. A.; LETTINGA, G. (1997). Anaerobic tolerance to oxygen and the potential of anaerobic cocultures for wastewater treatment. Brazilian Journal of Chemical Engineering, 14, pp.395-407.

KATO, M. T.; ANDRADE NETO, C. O.; CHERNICHARO, C. A. L.; FORESTI, E.; CYBIS, L. F. (1999). Configurações de reatores anaeróbios. In: Tratamento de esgotos sanitários por processo anaeróbio e disposição controlada no solo. CAMPOS, J. R. (coord.). ABES, Rio de Janeiro, pp.53-99.

KENNEDY, K. J.; SANCHEZ, W. A.; HAMODA, M. F.; DROSTE, R. L. (1991). Performance of anaerobic sludge blanket sequencing batch reactors. Research Journal of Water Pollution Control Federation, 63, pp.75-83.

LETTINGA, G. (1994). Anaerobic treatment of very low strength and cold industrial and domestic wastewaters. In: Anais do III Taller y Seminário Latino AmericanoTratamiento Anaeróbio de Águas Residuales. VIÑHAS, M.; SOUBES, M.; BORZACCONI, L.; MUXI, L. (eds.). Montevidéo, pp.155-168.

LIU, Y.; XU, H. L.; SHOW, K. Y.; TAY, J. H. (2002). Anaerobic granulation technology for wastewater treatment. World Journal of Microbiology and Biotechnology,18, pp.99-113.

MASSÉ, D. I.; PATNI, N. K.; DROSTE, R. L.; KENNEDY, K. J. (1996). Operation strategies for psychrophilic anaerobic digestion of swine manure slurry in a sequencing batch reactors. Canadian Journal of Civil Engineering, 23, pp.12851294. 
MASSÉ, D. I.; DROSTE, R. L.; KENNEDY, K.; PATNI, N. K.; MUNROE, J. A. (1997). Potential for the psychrophilic anaerobic treatment of swine manure using a sequencing batch reactor. Canadian Agricultural Engineering, 39, pp.2533.

MASSÉ, D. I.; MASSE, L. (2001). The effect of temperature on slaughterhouse wastewater treatment in anaerobic sequencing batch reactors. Bioresource Techology, 76, pp.91-98.

McCARTY, P. L. (1982). One hundred years of anaerobic treatment. In: Anaerobic Digestion. HUGHES, D. E. (ed.), Elsevier Biomedical Press B. V.

MOSEY, F. E. (1983). Mathematical modeling of the anaerobic process: regulatory mechanisms for the formation of short-chain volatile acids from glucose. Water Science and Technology, 15, pp.209-232.

NDON, U .J.; DAGUE, R .R. (1997a) Effects of temperature and hydraulic retention time on anaerobic sequencing batch reactor treatment of low-strength watewater. Water Research, 31, pp.2455-2466.

NDON, U. J.; DAGUE, R. R. (1997b). Ambient temperature treatment of low strength wastewater using anaerobic sequencing batch reactor. Biotechnology Letters, 19, pp.319-323.

NDON, U. J.; RANDALL, A. A. (1999). Periodic aerated treatment and in situ bioremediation strategies for polyhaloge nated compounds. WaterResearch, 33, pp. 2715-2720.

NG, W. J. (1989). A sequencing batch anaerobic reactor for treating piggery wastewater. Biological Wastes. 28, pp.39-51. 
ORTEGA, F. S.; ROCHA, K. M.; ZAIAT, M.; PANDOLFELLI, V. C. (2001). Aplicação de espumas cerâmicas produzidas via gelcasting em biorreator para tratamento anaeróbio de águas residuárias. Revista Cerâmica, 47, pp.199-203.

PARKIN, G. F.; SPEECE, R. E.; YANG, C; H. J.; KOCHER, W. M. (1983). Response of methane fermentation systems to industrial toxicants. Journal of Water Pollution Control Federation, 55, pp.44-53.

PELCZAR Jr, M. J.; CHAN, E. C. S.; KRIEG, N. R. (1996). Microbiologia: conceitos e aplicações. v.2, 2. ${ }^{\mathrm{a}}$ ed. Makron Books.

PESSÔA, C. A.; JORDÃO, E. P. (1982). Tratamento de esgotos domésticos. Volume 1: Concepções clássicas de tratamento de esgotos. 2. ${ }^{\mathrm{a}}$ ed., ABES, Rio de Janeiro, $536 \mathrm{p}$.

PFEFFER, J. T. (1979). Anaerobic digestion processes. In: Proceedings of the $5^{\text {th }}$ International Symposium on Anaerobic Digestion. STAFFORD, D. A.; WHEATLEY, B. I.; HUGHES, D. E. (eds.), Cardiff, pp.15-36.

POHLAND, F. (1998). Full-scale applications of anaerobic treatment technology: barriers to deployment. In: Anais do V Taller y Seminário Latino AmericanoTratamiento Anaeróbio de Águas Residuales. Viña del Mar, pp.1-6.

PRESS, W. H.; FLANNERY, B. P.; TEUKOLSKY, S. A.; VETTERLING, W. T. (1986). Numerical recipes- The art of scientific computing. Cambridge University Press, Cambrige.

RATUSZNEI, S. M.; RODRIGUES, J. A. D.; CAMARGO, E. F. M.; ZAIAT, M.; BORZANI, W. (2000). Feasibility of a stirred anaerobic sequencing batch reactor containing immobilized biomass for wastewater treatment. Bioresource Technology, 75, 127-132. 
RATUSZNEI, S. M.; RODRIGUES, J. A. D.; CAMARGO, E. F. M.; ZAIAT, M.; BORZANI, W. (2001). Influence of agitation rate on the performance of a stirred anaerobic sequencig batch reactor containing immobilized biomass. Water Science and Technology, 44, pp.305-312.

RATUSZNEI, S. M.; RODRIGUES, J. A. D.; CAMARGO, E. F. M.; RIBEIRO, R.; ZAIAT, M. (2003). Effects of feeding strategy on the stability and efficiency of a stirred anaerobic sequential fed-batch reactor containing immobilized biomass. Bioresource Technology (no prelo).

REYES III, F. L.; DAGUE, R. R. (1995). Effects of initial seed concentration on the startup of anaerobic sequencing batch reactor. In: $50{ }^{\text {th }}$ Purdue Industrial Waste Conference Proceedings. Ann Arbor Press., pp.449-459.

RIBEIRO, R. (2001). Influência do tipo de substrato na dinâmica de formação do biofilme em matrizes de espuma de poliuretano. Dissertação de mestrado. Escola de Engenharia de São Carlos, Universidade de São Paulo. São Carlos.

RIPLEY, L. E.; BOYLE, W. C.; CONVERSE, J. C. (1986). Improved alkalimetric monitoring anaerobic digestion of high-strenght wastes. Journal of water pollution control federation, 58, pp.406-411.

RODRIGUES, J. A. D., RATUSZNEI, S. M., ZAIAT, M. (2003). Fed-batch and batch operating mode analysis of a stirred anaerobic sequencing reactor with selfimmobilized biomass treating low-strength wastewater. Advanced in Environmental Research (submetido).

RUIZ, C.; TORRIJOS, M.; SOUSBIE, P.; LEBRATO MARTINEZ, J.; MOLETTA, R.; DELGENÈS, J. P. (2001). Treatment of winery wastewater by an anaerobic 
sequencing batch reactor (ASBR). In: Proceedings of $9{ }^{\text {th }}$ World Congress on Anaerobic Digestion, Antuérpia, pp.347-353.

SCHMIDT, C. G.; DAGUE, R. R. (1993). Anaerobic sequencing batch reactor treatment of swine wastes at $20^{\circ} \mathrm{C}, 25^{\circ} \mathrm{C}$ and $35^{\circ} \mathrm{C}$. In: $50 .^{\text {th }}$ Purdue Industrial Waste Conference Proceedings. Ann Arbor Press., pp.541-549.

SHIZAS, I.; BAGLEY, D. M. (2002). Improving anaerobic sequencing batch reactor performance by modifying operational parameters. Water Research, 36, pp.363367.

SINGH, R. P.; KUMAR, S.; OJHA, C. S. P. (1999). Nutrient requirement for UASB process: a review. Biochemical Engineering Journal, 3, pp.35-54.

SPEECE, R. E. (1996). Anaerobic biotechnology for industrial wastewater treatment. Ed. Archae Press, Nashville, 394p.

SUNG, S.; DAGUE, R. R. (1995). Laboratory studies on the anaerobic sequencing batch reactor. Water Environmental Research, 67, pp.294-301.

SUTHAKER, S.; POLPRASET, C.; DROSTE, R. L. (1991). Sequencing batch anaerobic reactors for treatment of a high-strength organic wastewater. Water Science and Technology, 23, pp.1249-1257.

TIMUR, H.; ÖSTURK, I. (1999). Anaerobic sequencing batch reactor treatment of landfill leachate. Water Research, 33, pp.3225-3230.

TORRES, P. (1992). Desempenho de um reator anaeróbio de manta de lodo (UASB) de bancada no tratamento de substrato sintético simulando esgotos sanitários. Dissertação de mestrado. Escola de Engenharia de São Carlos, Universidade de São Paulo. São Carlos, 174p. 
VALLERO, M. V. G. (1999). Avaliação da atividade biológica das células livres e imobilizadas formadas em um reator anaeróbio. Dissertação de mestrado. Escola de Engenharia de São Carlos, Universidade de São Paulo. São Carlos, 151p.

van HAANDELL, A. C.; LETTINGA, G. (1994). Tratamento anaeróbio de esgotos. Um manual para regiões de clima quente. UFPb, Campina Grande, 232p.

VARESCHE, M.B.; ZAIAT, M.; VIEIRA, L.G.T.; VAZOLLER, R.F.; FORESTI, E. (1997). Microbial colonization of polyurethane foam matrices in horizontalflow anaerobic immobilized-sludge reactor. Applied Microbiology Biotechnology, 48, pp.534-538.

VAZOLLER, R. F.; MANFIO, G. P.; CANHOS, V. P. (1999). Diversidade do domínio Archae. In: Biodiversidade no estado de São Paulo, Brasil. Volume 1: Microrganismos e vírus. CANHOS, V. P.; VAZOLLER, R. F. (eds.) FAPESP, São Paulo, pp.15-24.

VERRIER, D.; MORTIER, B.; ALBAGNAC, G. (1987). Initial adhesion of methanogenic bactéria to polymers. Biotechnology Letters, 9, pp.735-740.

von SPERLING, M. (1996). Princípios do tratamento biológico de águas residuárias. Volume 1: Introdução à qualidade das águas e ao tratamento de esgotos. DESA/UFMG, Belo Horizonte, 243p.

WELPER, L. L.; SUNG, S.; DAGUE, R. R. (1997). Laboratory studies on the temperature-pHased ASBR system. Water Science and Technology, 36, pp.295302.

WIRTZ R. A.; DAGUE, R. R. (1996). Enhancement of granulation and start-up in the anaerobic sequencing batch reactor. Water Environmental Research, 68, pp.883-892. 
WIRTZ R. A.; DAGUE, R. R. (1997). Laboratory studies on enhancement of granulation in the anaerobic sequencing batch reactor. Water Science and Technology, 36, pp.279-286.

ZAIAT, M.; CABRAL, A. K. A.; FORESTI, E.; (1994). Horizontalflow anaerobic immobilized sludge reactor for wastewater treatment: Conception and performance evaluation. Revista Brasileira de Engenharia- Caderno de Engenharia Química, 11, pp.33-42.

ZAIAT, M.; RODRIGUES, J. A. D.; RATUSZNEI, S. M.; CAMARGO, E F. M.; BORZANI, W. (2001). Anaerobic sequencing batch reactors for wastewater treatment: A developing technology. Applied Microbiology and Biotechnology, 55, pp.29-35. 


\section{APÊNDICES}

DADOS DISPONIVEIS NA VERSÃO IMPRESSA 